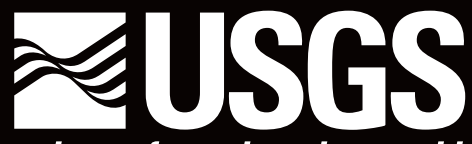

science for a changing world
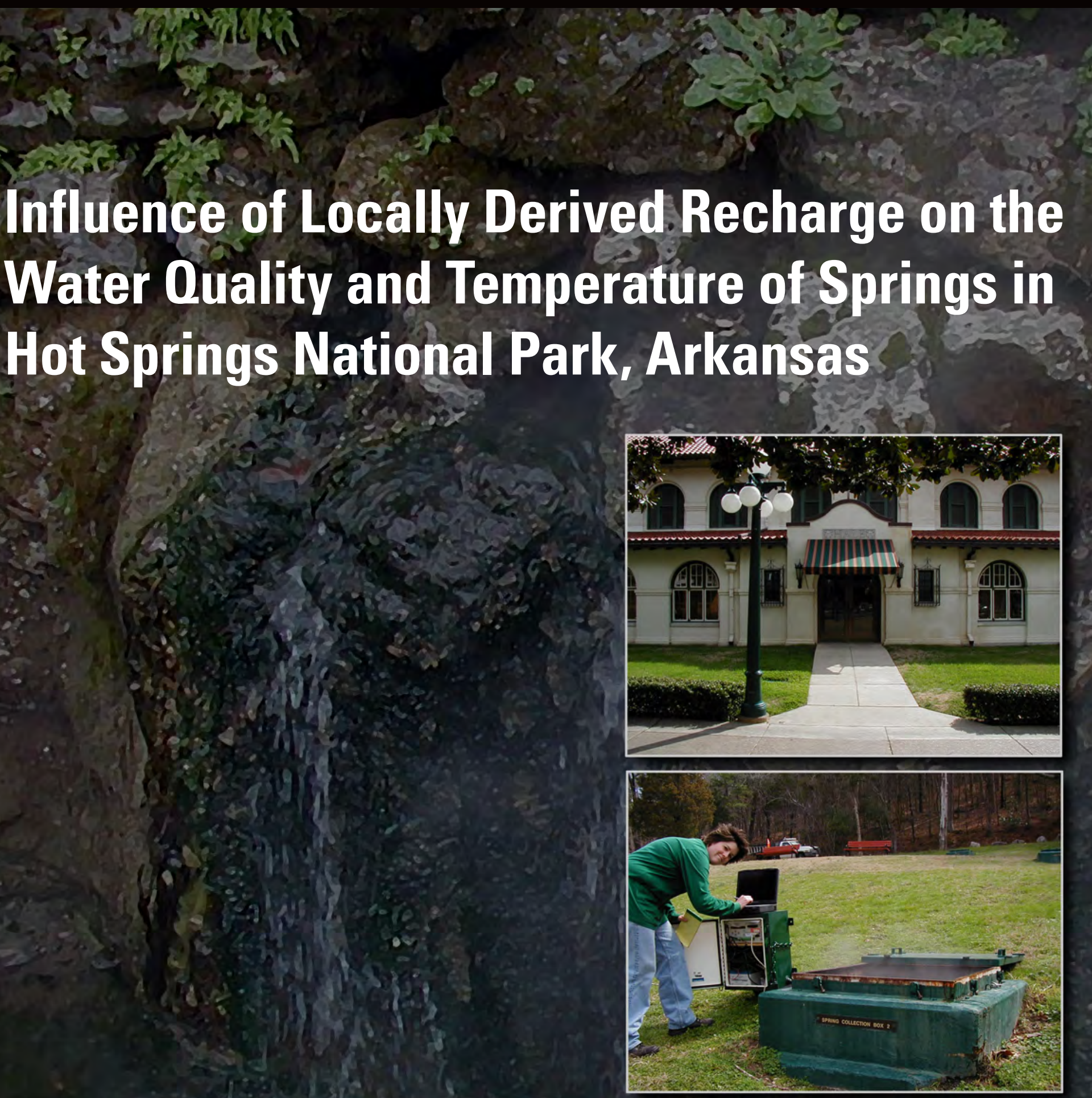

Scientific Investigations Report 2007-5004 
Cover photographs: Hale Bathhouse, 2002 (top, right, photograph from the U.S. Geological Survey).

Downloading temperature data at collection box, 2002 (bottom, right, photograph from the U.S. Geological Survey). 


\section{Influence of Locally Derived Recharge on the Water Quality and Temperature of Springs in Hot Springs National Park, Arkansas}

By Richard W. Bell and Phillip D. Hays

Scientific Investigations Report 2007-5004 


\section{U.S. Department of the Interior DIRK KEMPTHORNE, Secretary}

\section{U.S. Geological Survey \\ Mark D. Myers, Director}

\section{U.S. Geological Survey, Reston, Virginia: 2007}

For product and ordering information:

World Wide Web: http://www.usgs.gov/pubprod

Telephone: 1-888-ASK-USGS

For more information on the USGS--the Federal source for science about the Earth, its natural and living resources, natural hazards, and the environment:

World Wide Web: http://www.usgs.gov

Telephone: 1-888-ASK-USGS

Any use of trade, product, or firm names is for descriptive purposes only and does not imply endorsement by the U.S. Government.

Although this report is in the public domain, permission must be secured from the individual copyright owners to reproduce any copyrighted materials contained within this report.

Suggested citation:

Bell, R.W., and Hays, P.D., 2007, Influence of locally derived recharge on the water quality and temperature of springs in Hot Springs National Park, Arkansas: U.S. Geological Survey Scientific Investigations Report 2007-5004, 45 p. 


\section{Contents}

Abstract

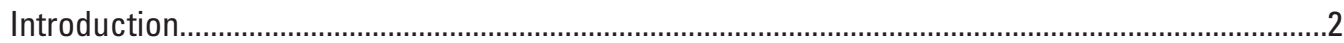

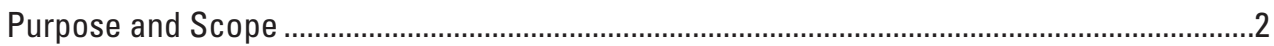

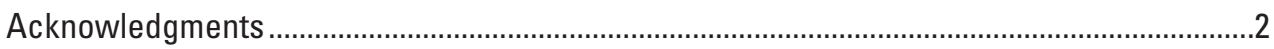

Overview of Geologic and Hydrologic Setting ......................................................................

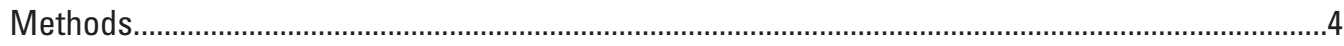

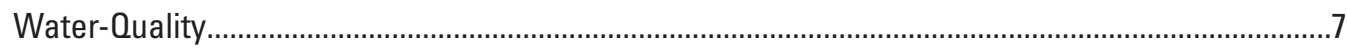

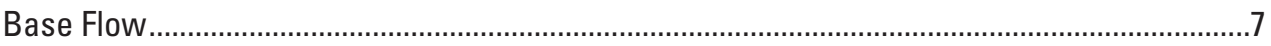

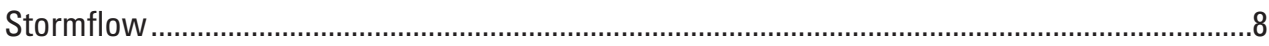

Water Temperature of the Springs ........................................................................................

Influence of Locally Derived Recharge on the Water Quality and Temperature of Springs...........11

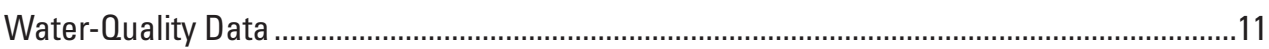

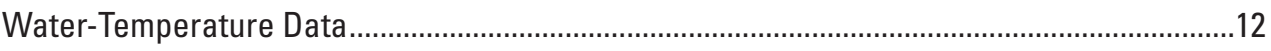

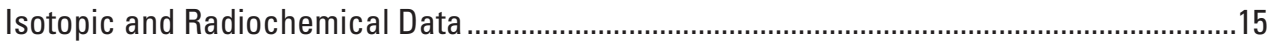

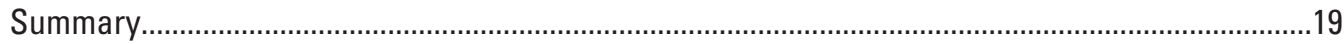

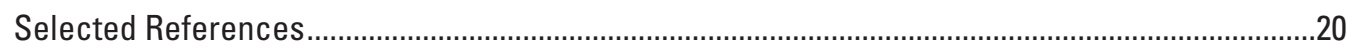

\section{Figures}

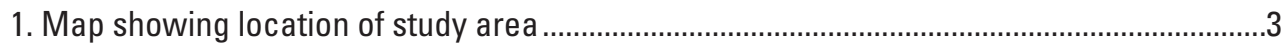

2. Map showing location of sampling sites ........................................................................

3-9. Graphs Showing:

3. Graph showing water temperature at hot springs equipped with continuous recorders....10

4. Graphs showing relation between silica concentration and water temperature .................11

5. Graph showing relation between water temperature decreases and precipitation at

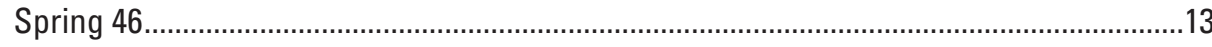

6. Graph showing relation between discharge and water-temperature data at the Hot Springs National Park spring reservoir, showing the period of record-water years 1991 through 2005

7. Graphs showing relation between discharge and water-temperature data at the Hot Springs National Park spring reservoir, April 1991 .........................................................14

8. Graph showing relation between deuterium/hydrogen and oxygen-18/oxygen-16

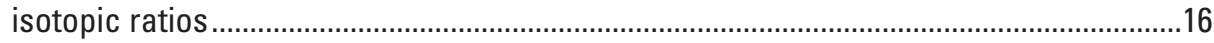

9. Graphs showing relation between strontium-87/strontium-86 and strontium......................18

\section{Tables}

1. Generalized section of sedimentary rocks in the vicinity of the hot springs .........................4

2. Information for spring and precipitation sites sampled.................................................6

3. Nutrient, major ion, trace element, isotope, radiochemical, physical property, field measurement, and bacteria data for samples collected at hot- and cold-water springs in 2000 and 2001 
4. Pesticide and semivolatile concentrations for samples collected at hot- and coldwater springs in 2000 and 2001.

5. Nutrient, major ion, trace element, isotope, radiochemical, physical property, and field-measurement data for samples collected at hot- and cold-water springs in water years 1972, 2000, and 2001.

6. Temperature of selected hot springs

7. Summary of statistical tests for selected constituents and physical property differences between base-flow and stormflow samples.

8. Cold-water fraction estimates calculated from silica and total dissolved solids data for base-flow and stormflow conditions

\section{Conversion Factors, Vertical Datum, and Abbreviations}

\begin{tabular}{lcl}
\hline \multicolumn{1}{c}{ Multiply } & By & \multicolumn{1}{c}{ To obtain } \\
\hline inch (in.) & 2.54 & centimeter $(\mathrm{cm})$ \\
foot $(\mathrm{ft})$ & 0.3048 & meter $(\mathrm{m})$ \\
square foot $\left(\mathrm{ft}^{2}\right)$ & 0.0929 & square meter $\left(\mathrm{m}^{2}\right)$ \\
square mile $\left(\mathrm{mi}^{2}\right)$ & 2.590 & square kilometer $\left(\mathrm{km}^{2}\right)$ \\
cubic foot $\left(\mathrm{ft}^{3}\right)$ & 7.481 & gallon $($ gal) \\
\hline
\end{tabular}

Temperature in degrees Celsius $\left({ }^{\circ} \mathrm{C}\right)$ may be converted to degrees Fahrenheit $\left({ }^{\circ} \mathrm{F}\right)$ as follows: ${ }^{\circ} \mathrm{F}=\left(1.8 \mathrm{x}{ }^{\circ} \mathrm{C}\right)+32$ In this report, horizontal coordinate information is referenced to the North American Datum of 1927 (NAD 27). Water year is the 12-month period October 1 through September 30.

\section{Abbreviations and Acronymns Used in this Report}

$\mathrm{mg} / \mathrm{L}$, milligrams per liter

$\mathrm{mBq} / \mathrm{L}$, milli-Becquerels per liter

$\mathrm{pCi} / \mathrm{L}$, picocuries per liter

$\mu \mathrm{g} / \mathrm{L}$, microgram per liter

$\mu \mathrm{S} / \mathrm{cm}$, microsiemens per centimeter at 25 degrees Celsius

$\%$, parts per thousand (per mil)

HNSP, Hot Springs National Park

MRL, method reporting limit

$M C L$, maximum contaminant level

SVOC, semivolatile organic compounds

TDS, total dissolved solids

VSMOW, Vienna Standard Mean Ocean Water 


\title{
Influence of Locally Derived Recharge on the Water Quality and Temperature of Springs in Hot Springs National Park, Arkansas
}

\author{
By Richard W. Bell and Phillip D. Hays
}

\begin{abstract}
The hot springs of Hot Springs National Park consist of a mixture of water from two recharge components: a primary hot-water component and a secondary cold-water component. Widespread distribution of fractures enables mixing of the hotand cold-water components of flow near the discharge area for the springs. Urbanization in the area near the hot springs of Hot Springs National Park has increased the potential for degradation of the quality of surface-water runoff and locally derived ground-water recharge to the hot springs. Previous studies by the U.S. Geological Survey have indicated that water from some cold-water springs and wells in the vicinity of Hot Springs, Arkansas, showed evidence of contamination and that water from locally derived cold-water recharge might contribute 25 percent of the total flow to the hot springs after storms.
\end{abstract}

Water samples were collected during base-flow conditions at nine hot springs and two cold-water springs in September 2000. Nine hot springs and one cold-water spring were resampled in October 2001 after a storm that resulted in a measurable decrease in water temperature in selected hot springs. Water samples were analyzed for a variety of dissolved chemical constituents (nutrients, major ions, trace elements, pesticides, semivolatile compounds, isotopes, and radiochemicals), physical properties, field measurements, and bacteria.

Comparison of analyses of samples collected during base-flow conditions from the springs in 2000 and during a storm event in 2001 with the results from earlier studies dating back to the late 1800's indicates that little change in major, minor, and trace constituent chemistry has occurred and that the water continues to be of excellent quality.

Water-quality data show distinguishable differences in water chemistry of the springs during base-flow and stormflow conditions, indicating changing input of cold-water recharge relative to hot-water recharge. Silica, total dissolved solids, strontium, barium, and sulfate show statistically significant differences between the median values of base-flow and stormflow samples. While variations in these constituents do not degrade water quality, the differences do provide evidence of variability in the factors controlling water quality of the hot springs and show that water quality is influenced by the locally derived, cold-water component of flow to the springs.

Water temperature was measured continuously (3-minute intervals) between August 2000 and October 2002 at four hot springs. Continuous water-temperature data at the springs provide no indication of persistent long-term change in water temperature through time.

Short time-scale water-temperature decreases occur in response to mixing of hot-springs water with locally derived recharge after storm events; the magnitude of these decreases varied inversely with the amount of rainfall. Maximum decreases in water temperature for specific storms had a nonlinear relation with the amount of precipitation measured for the events.

Response time for water temperature to begin decreasing from baseline temperature as a result of storm recharge was highly variable. Some springs began decreasing from baseline temperature as quickly as 1 hour after the beginning of a storm; one spring had an 8-hour minimum response time to show a storm-related temperature decrease.

Water-quality, water-temperature, isotopic, and radiochemical data provide multiple lines of evidence supporting the importance of the contribution of cold-water recharge to hot springs. All the springs sampled indicated some measure of influence from local recharge. Binary mixing models using silica and total dissolved solids indicate that coldwater recharge from stormflow contributes an estimated 10 to 31 percent of the flow of hot springs. Models using water temperature indicate that cold-water recharge from stormflow contributes an estimated 1 to 35 percent of the flow of the various hot springs. Although these data indicate that cold-water recharge from stormflow does contribute to the flow of the hot springs, data from additional stormflow events and also from additional hot springs are needed to rigorously define the variability and contribution of cold-water recharge. 


\section{Introduction}

The hot springs of Hot Springs National Park (HSNP), located in Hot Springs, Arkansas (fig. 1), have been a natural resource of international renown and popular utility for many years. The first scientific study of the springs was initiated by President Thomas Jefferson in 1804; a later request for efficacious use and proper management of the springs resulted in creation of the Hot Springs Reservation in 1832 and designation as a federally managed national park in 1921. The national park designation serves to preserve and protect the natural and cultural resources of the area for present and future generations.

The hot springs are valued as a source of drinking water and for the recreational and therapeutic benefits of the hot water baths. In 2002, about 1.4 million people made recreational visits to HSNP, more than 100,000 people bathed in the hot waters, and additional tens of thousands of people collected water for drinking (D. East, National Park Service, oral commun., 2003).

Urbanization in the area near the hot springs has increased the potential for degradation of the quality of surface-water runoff and locally derived ground-water recharge to the springs (Hansen and Gryskiewicz, 2003). Potential degradation of runoff and recharge may result from contaminants leaking from sewer systems and underground storage tanks, contaminants from chemical-intensive commercial activities where spills or improper disposal may occur, and contaminants from nonpoint source runoff such as lawns, parking lots, and roads. Because of the increased vulnerability of the hot springs as the area near the HSNP undergoes development, the National Park Service's (NPS) Resources Management Plan includes a section stating that the Park was created to provide hot water to the public and that protecting the hot-water resource is an important resource-management goal (National Park Service, 1998).

Previous studies (Bedinger and others, 1979; C.S. Barks, U.S. Geological Survey, written commun., 1995) conducted by the NPS and the U.S. Geological Survey (USGS) have indicated that much of the water issuing from the hot springs is approximately 4,400 years old and for the next four millennia this component of flow is unlikely to show any deterioration in water quality resulting from development and urbanization of the area near the Park. However, these same studies have indicated that an unquantified component of flow from the springs is of recent origin; this component of flow is derived from a recharge area that contributes relatively cold water to the hot springs. The recharge area for the cold-water component of recharge is (1) probably not contiguous with the hot-water recharge area with the cold-water component following a very different, shallower, flowpath, (2) likely of limited areal extent, and (3) probably located near the discharge area of the springs.

The most comprehensive previous study of the hot springs (Bedinger and others, 1979) provided evidence that the hot springs consist of a mixture of water from two sources: a primary source about 4,400 years old and a secondary source less than 20 years old. In addition, the study indicated that a component of flow to some cold-water springs and wells in the Hot Springs area showed evidence of contamination, such as elevated concentrations of nitrate and chloride. Water temperature and flow data collected by the USGS in the mid-1990's at the HSNP spring reservoir (C.S. Barks, U.S. Geological Survey, written commun., 1995) indicated that a storm event strongly affected hot springs discharge and temperature. Data from this study indicated that water from locally derived recharge areas might contribute 25 percent of the total flow to the hot springs after such a storm.

The results of these two studies suggest the potential for degradation of water quality in the hot springs by locally derived recharge, which could have important ramifications for public health and for management of the hot springs water resource. However, water quality and the presence of contaminants in the locally derived component of the hot springs have not been adequately characterized for either base-flow or stormflow conditions.

\section{Purpose and Scope}

The purpose of this report is to identify any influence of locally derived recharge on the water quality and temperature of hot springs. Information includes (1) water-quality data from nine hot springs and two cold-water springs sampled in 2000 and 2001 for comparison with water-quality and temperature measurements from previous studies of the hot springs and (2) characterization of the variability of water temperature for the hot springs. For the water-quality component of the study, samples from springs were collected in 2000 during base-flow conditions; additional samples, from the same springs, were collected in 2001 during stormflow conditions. To describe variability of water temperature, data from temperature recorders deployed at four hot springs were evaluated. To describe the influence of locally derived recharge on the hot springs, differences in concentrations of selected chemical constituents, isotopes, physical properties, and field measurements were evaluated for the base-flow samples and stormflow samples.

\section{Acknowledgments}

The assistance of Steve Rudd of HSNP is gratefully acknowledged. His knowledge of the springs and cooperation in providing access to spring boxes and bathhouses streamlined sample-collection activities. Marsha Gipson and Rene Freret of the USGS installed and maintained temperature recorders. Kenny Knox of the Hot Springs Fire Department provided information about rainfall events. We also thank Jerome and Betty Whipple for providing access to the ArScenic cold-water spring. 

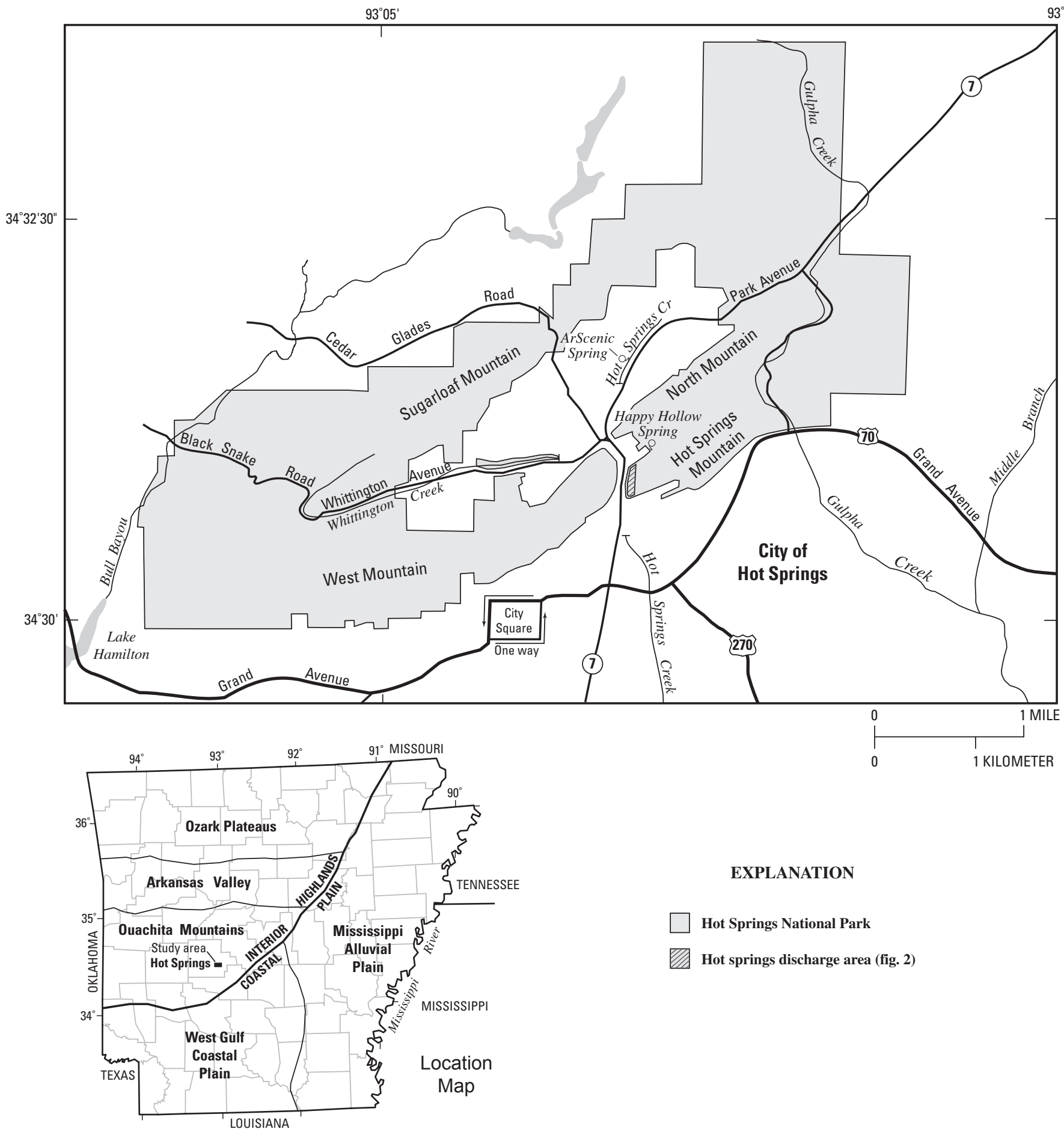

\section{EXPLANATION}

Hot Springs National Park

Hot springs discharge area (fig. 2)

Figure 1. Location of study area (sampling locations are shown on figure 2). 


\section{Overview of Geologic and Hydrologic Setting}

This section of the report provides a brief description of the geology and hydrology affecting the hot springs at HSNP. For a more detailed review of the geology and hydrology, the reader is referred to the discussions in Bedinger and others (1979).

The rocks cropping out in the vicinity of the hot springs are primarily sedimentary rocks of Paleozoic age (table 1). Shale, sandstone, chert, and novaculite predominate in local outcrops. Rocks in the Hot Springs area have undergone at least three episodes of compressional deformation. These deformation episodes resulted in a series of thrust faults and overturned complexly folded anticlines trending in a northeast-southwest direction.

Table 1. Generalized section of sedimentary rocks in the vicinity of the hot springs.

[0, outcrops in the vicinity of Hot Springs National Park; modified after Bedinger and others, 1979]

\begin{tabular}{|c|c|c|}
\hline System & Formation & $\begin{array}{c}\text { Maximum } \\
\text { thickness in } \\
\text { Hot Springs area } \\
\text { (feet) }\end{array}$ \\
\hline \multirow{3}{*}{ 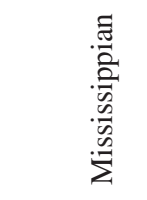 } & Stanley Shale (o) & 8,500 \\
\hline & Hot Springs Sandstone (o) & 150 \\
\hline & \multirow[t]{2}{*}{ Arkansas Novaculite (o) } & \multirow{2}{*}{650} \\
\hline Devonian & & \\
\hline Silurian & \multirow{2}{*}{$\begin{array}{l}\text { Missouri Mountain Shale, (o) } \\
\text { Blaylock Sandstone, and } \\
\text { Polk Creek Shale, undif- } \\
\text { ferentiated }\end{array}$} & \multirow[b]{2}{*}{195} \\
\hline \multirow{3}{*}{$\begin{array}{l}\frac{\pi}{0.0} \\
\frac{0}{2} \\
0 \\
0 \\
0\end{array}$} & & \\
\hline & Bigfork Chert (o) & 700 \\
\hline & Womble Shale & 1,500 \\
\hline
\end{tabular}

The hot waters are thought to enter the ground-water system, within a few tens of miles of HSNP, as meteoric water from a recharge area in the fractured, highly permeable Bigfork Chert and Arkansas Novaculite that outcrop in exposed anticline structures to the west, north, and northeast of the hot springs discharge area. The waters migrate to estimated minimum depths of 4,400 to $7,500 \mathrm{ft}$, at which depths a geothermal temperature gradient between $0.006{ }^{\circ} \mathrm{C} / \mathrm{ft}$ and $0.01{ }^{\circ} \mathrm{C} / \mathrm{ft}$, would allow the water to achieve the high temperatures in the deep section of the flow path before passing through fault and fracture conduits in the relatively impermeable shales of the Polk Creek and Missouri Mountain Shale. The hot waters reemerge through the Hot Springs Sandstone between the traces of two thrust faults, along several northeasttrending lineaments (Bedinger and others, 1979).

The locally derived, cold-water component of flow in the hot springs is probably similar in origin to water in cold-water wells that tap shallow ground water in the area and to water emerging from cold-water springs common in the immediate area of HSNP. Spring resurgence zones are areas where hydrogeologic conditions-structural, stratigraphic, petrologic, and hydrologic influences on permeability distribution and permeability contrasts-cause convergence of groundwater flow lines and integration of ground-water flow. Rocks that carry the cold-water component of flow in the Hot Springs area are extensively fractured, allowing water to move rapidly through fracture conduits in the rock. The widespread distribution of fractures enables integration and mixing of the hot- and cold-water components of flow in the resurgence zone; mixing probably occurs where the hot waters emerge from the deep portion of the flow path into the shallow ground-water zone (Bedinger and others, 1979).

\section{Methods}

Water samples were collected from 11 springs in the study area (figs. 1 and 2; table 2) in September 2000 and 10 of the springs were resampled in October 2001. The springs were selected for sampling based on several criteria: sufficient flow, accessibility, and location-springs located along Central Avenue and east of the promenade (fig. 2) were included to monitor variability related to elevation. Spring numbers and names in table 2 have the same nomenclature used by Bedinger and others (1979). A precipitation sample also was collected in October 2001. Of the 11 samples collected in 2000, 9 hot springs and 2 cold springs were analyzed for a broad suite of chemical constituents, physical properties, field measurements, and bacteria (tables 3, 4, and 5 (located at the end of the report)). All nine hot springs and one cold spring were resampled in October 2001. The September 2000 samples were collected during base-flow conditions; the October 2001 samples were collected after a storm that resulted in a measurable decrease in water temperature in four selected hot springs equipped with continuous temperature recorders. As part of the stormflow sampling effort, a precipitation sample was collected at the NPS meteorological station near Hot Springs Mountain Drive; the sample was analyzed for sulfate and the following isotopes: sulfur-35 $\left({ }^{35} \mathrm{~S}\right)$, deuterium $\left({ }^{2} \mathrm{H}\right)$, and oxygen-18 $\left({ }^{18} \mathrm{O}\right)$.

Water-quality samples were collected using USGS lowlevel techniques (Koterba and others, 1995). Analyses for nutrients, major ions, trace elements, semivolatile compounds, and pesticides were performed at the Severn Trent Laboratory in Denver, Colorado; analyses for radiochemicals and isotopes were performed at USGS Water Resources Discipline Laboratories in Reston, Virginia, and Menlo Park, California. 


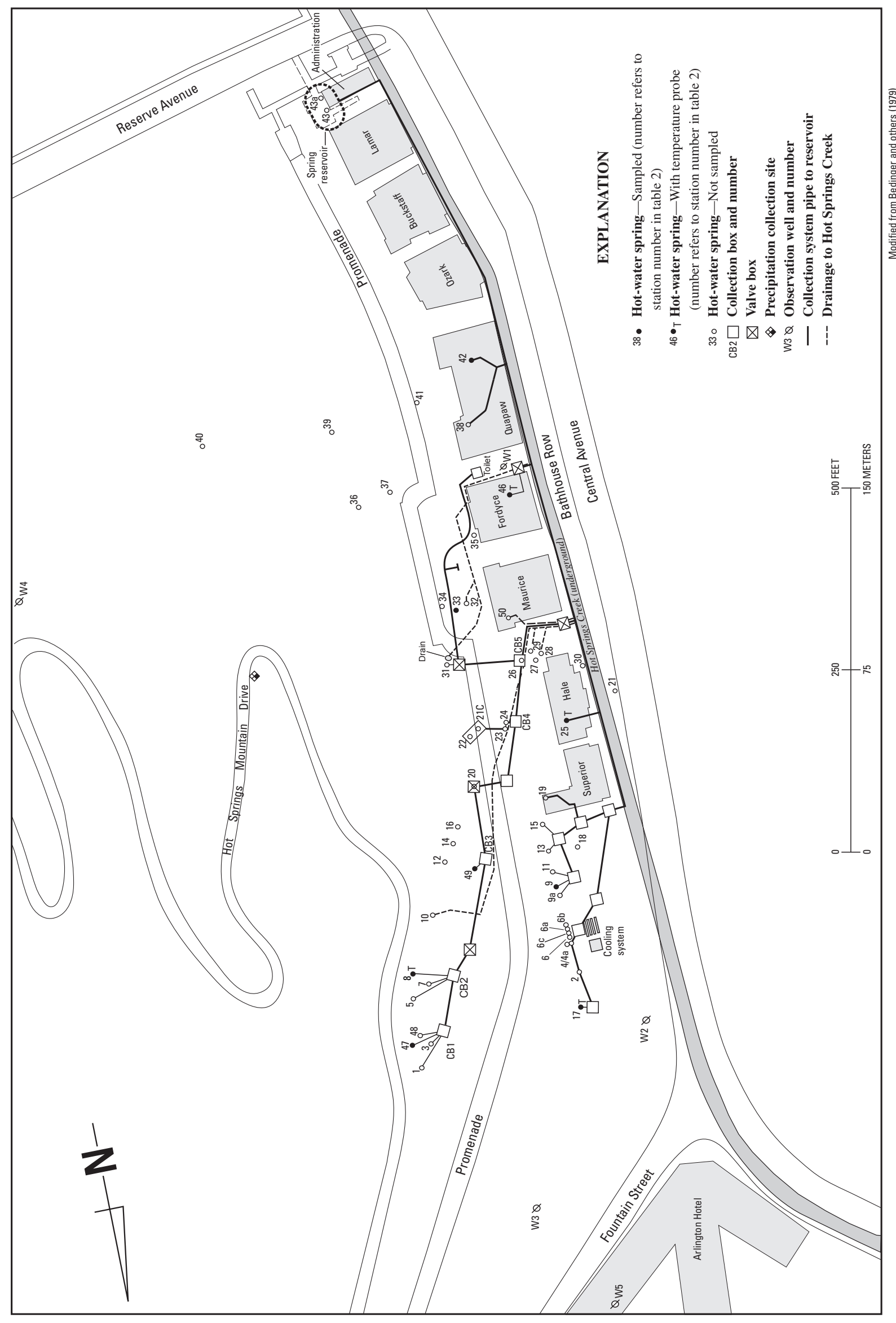

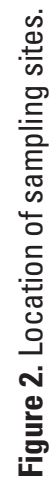


Table 2. Information for spring and precipitation sites sampled.

[N, no; Y, yes]

\begin{tabular}{|c|c|c|c|c|c|c|c|}
\hline Station number & Spring number or site name & $\begin{array}{l}\text { Type of } \\
\text { spring }\end{array}$ & Latitude & Longitude & $\begin{array}{c}\text { Sampled } \\
\text { in } 2000\end{array}$ & $\begin{array}{c}\text { Sampled } \\
\text { in } 2001\end{array}$ & $\begin{array}{c}\text { Continuous } \\
\text { temperature } \\
\text { recorder }\end{array}$ \\
\hline 343058093030901 & Spring 47 & hot & 343058 & 0930309 & $\mathrm{Y}$ & $\mathrm{Y}$ & $\mathrm{N}$ \\
\hline 343056093030901 & Spring 8 & hot & 343056 & 0930309 & $\mathrm{Y}$ & $\mathrm{Y}$ & $\mathrm{Y}$ \\
\hline 343054093031201 & Spring 49 & hot & 343054 & 0930312 & $\mathrm{Y}$ & $\mathrm{Y}$ & $\mathrm{N}$ \\
\hline 343055093031301 & Spring 9 & hot & 343055 & 0930313 & $\mathrm{Y}$ & $\mathrm{Y}$ & $\mathrm{N}$ \\
\hline 343052093031301 & Spring 25 (Hale Bathhouse) & hot & 343052 & 0930313 & $\mathrm{Y}$ & $\mathrm{Y}$ & $\mathrm{Y}$ \\
\hline 343050093031201 & Spring 33 (Upper Display Spring) & hot & 343050 & 0930312 & $\mathrm{Y}$ & $\mathrm{Y}$ & $\mathrm{N}$ \\
\hline 343049093031301 & Spring 46 (Fordyce Bathhouse) & hot & 343049 & 0930313 & Y & $\mathrm{Y}$ & Y \\
\hline 343110093025301 & Happy Hollow & cold & 343110 & 0930253 & $\mathrm{Y}$ & $\mathrm{Y}$ & $\mathrm{Y}$ \\
\hline 343051093030601 & Precipitation site & -- & 343051 & 0930306 & $\mathrm{~N}$ & $\mathrm{Y}$ & $\mathrm{N}$ \\
\hline
\end{tabular}

Temperature probes and recorders were used to monitor water temperature in four hot springs and one cold-water spring (table 2). Temperature probes capable of measuring water temperatures between -40 and $100{ }^{\circ} \mathrm{C}$ were deployed in the springs and bathhouses. In spring boxes, the probes were anchored with a stainless-steel weight in the mouth of the collection pipe approximately $0.4 \mathrm{ft}$ below the water surface. In bathhouses, the temperature probes were suspended below the water surface from tiles adjacent to the spring channel. Monitors that recorded water temperature at 3-minute intervals in the spring collection boxes and bathhouses were activated in August 2000.

A monitoring station located in the basement of the park administration building has been monitoring spring reservoir (fig. 2) discharge from October 1988 through June 2005 and temperature from October 1990 through June 2005. The monitoring station consists of a weir to measure the inflow from the collection system to the collection reservoir; a float device to measure the water level in the reservoir; a weir to measure the overflow from the reservoir to Hot Springs Creek; and a temperature probe located at the inflow weir to measure water temperature from the thermal springs. The inflow and overflow weirs were identical in design and construction and were installed side by side, but were oriented in opposite directions and at different elevations. The weirs were calibrated in a flume for discharges from 0.01 to 2.12 cubic feet per second $\left(\mathrm{ft}^{3} / \mathrm{s}\right)$, or 4.5 to 952 gallons per minute (gal/min), and rating equations were established to convert the water level in the weir boxes to discharge of water passing through the weirs. The water levels in the weirs and the reservoir were measured to one-hundredth of a foot, and the temperature measured to one-hundredth of a degree Celsius. All data were recorded at 15-minute intervals and transmitted every 4 hours. The methods used for measuring discharge followed Rantz and others, (1982), and the methods used for measuring temperature followed Wagner and others (2000).

The total discharge of the thermal springs for the period from October 1990 through June 2005 was determined by adding the total inflow to the collection reservoir and the estimated discharge from springs 43 and 43a that emerge from the open bottom of the collection reservoir. The discharge from springs 43 and 43a was estimated from three reservoir recovery tests conducted in 1989 (C.S. Barks, U.S. Geological Survey, written commun., 1989). The tests were conducted by diverting collection-system inflow to Hot Springs Creek and pumping down the water in the reservoir, allowing only springs 43 and 43a to discharge into the reservoir. The total discharge of springs 43 and 43 a were calculated from the recovery of the reservoir water level.

Amounts of precipitation and storm, start-time data were obtained from automated precipitation gages located in various parts of Hot Springs, Arkansas, and the precipitation site near Hot Springs Mountain Drive. The precipitation gages are operated by the Hot Springs Fire Department; the precipitation site is operated by the NPS.

Descriptive statistics are used to show the central tendency and variation in the data. The minimum, maximum, and median (50th percentile) are presented for the nine hot springs. Statistical tests (t-test and rank sum test) were used to evaluate statistically significant differences ( $\mathrm{p}$-values less than 0.05 ) between the median values of base-flow and stormflow samples for several constituents and physical properties. 
Binary mixing models are used to estimate the contribution of cold-water recharge to the hot springs. To calculate proportions of components involved in a mixture, the binary mixing equation (1) was used (Faure, 1977).

$$
X_{\text {mix }}=\left(X_{A}\right) f_{A}+\left(X_{B}\right) f_{B}
$$

where

$X_{\text {mix }}$ is the species concentration or isotopic composition of the mixture,

$X_{\mathrm{A}}$ is species concentration or isotopic composition of a component A contributing to a mixture,

$f_{\mathrm{A}}$ is the fraction of component A present in the mix, $X_{\mathrm{B}}$ is the species concentration or isotopic composition of a component B contributing to a mixture, and

$f_{\mathrm{B}}$ is the fraction of component $\mathrm{B}$ present in the mix and is equal to $l-f_{\mathrm{A}}$.

Many of the water-quality constituents from samples collected had "non-detected" concentrations. The concentrations reported for these constituents were variable, depending on the method used to perform the analysis for a specific constituent. The lower limits below which constituent concentrations cannot be measured within specified accuracy constraints were set by the threshold of laboratory analytical techniques and equipment. When the measured concentration of a constituent was less than this lower limit, the concentration was reported as less than or "below" the method-reporting limit (MRL). In some cases the laboratory might be confident that a value less than the MRL is "real"; these results are indicated as "estimated".

\section{Water-Quality}

As a unique water resource for drinking and primary contact such as bathing, the status of water quality and an understanding of changes in water quality through time for the hot springs are of critical importance. This importance and need for knowledge are heightened by evolving land use and urbanization in the hot-spring recharge and discharge areas. The following sections summarize the results of the water-quality analyses for samples collected during base flow and stormflow for a variety of constituents (nutrients, major ions, trace elements, field measurements, bacteria, and physical properties including water temperature). The results of the base-flow and stormflow samples are compared with water-quality data collected from previous investigations.

Water from the hot springs contains a variety of dissolved chemical constituents. Knowledge of the chemical types and concentrations can be used to interpret ground-water movement, source of the water, and temporal changes in chemical concentration (Bedinger and others, 1979). Comparison of analyses of samples collected from the springs during 2000 and 2001 with the results from earlier studies dating back to the late 1800's shows that little change in major, minor, and trace constituent chemistry has occurred and that the water continues to have excellent quality. Minor differences are apparent (silica, zinc, and nutrient concentrations) that may be a result of sampling different springs, plumbing modifications (engineered collection and distribution infrastructure), different analytical techniques, and the natural geochemical differences characteristic of most ground-water systems.

\section{Base Flow}

During base-flow conditions, with sampling being conducted near the end of the summer-fall dry season, concentrations of nutrient, major ion, trace element, pesticide and semivolatile compounds, as well as stable isotope, radiochemical, physical property, field measurement, and bacteria data were collected at nine hot springs and two cold springs. No constituents from the samples collected during the base-flow sampling event exceeded their respective drinking-water, maximum contaminant levels (MCL) set by the U.S. Environmental Protection Agency (U.S. Environmental Protection Agency, 2003) (table 3, located at end of report). The samples collected for the base-flow sampling event were collected following seasonal hydrologic conditions that were similar to conditions preceding the collection of samples reported by Bedinger and others (1979) in that no precipitation had occurred in the week prior to sampling.

Concentrations of five nutrient compounds (nitrogen ammonia; nitrogen nitrate; nitrite plus nitrate; phosphorus; orthophosphorus) were measured in hot-spring, base-flow samples. The concentrations generally were less than $0.5 \mathrm{mg} / \mathrm{L}$ and concentrations in many samples were below the MRL for the compound. The nutrient concentrations measured for the hot springs were comparable to those reported by Bedinger and others (1979) for samples collected in January 1972—no nitrate, ammonia, or organic nitrogen concentrations for samples collected in 1972 from the hot springs exceeded their respective 1972 MRL's. The nutrient concentrations measured in samples from the two cold springs also were less than 0.5 $\mathrm{mg} / \mathrm{L}$. These low concentrations were similar to concentrations reported by Bedinger and others (1979) for cold-water springs and wells in the vicinity of HSNP.

Concentrations of eight major ions were measured in hot-spring, base-flow samples (table 3 ). Concentrations were less than MRL's for samples analyzed for potassium, sodium, chloride, and fluoride. The major ions having the highest concentrations in the hot springs were calcium $(47.9 \mathrm{mg} / \mathrm{L})$ and silica $(46.9 \mathrm{mg} / \mathrm{L})$. Most of the major ion concentrations measured for the hot springs were comparable to those reported by Bedinger and others (1979) for samples collected in January 1972. Silica concentrations reported by Bedinger and others (1979) for the hot springs were smaller than those determined for base-flow samples in this study. Analyses for silica in hot 
spring samples collected in 1972 (Bedinger and others 1979) were very consistent, ranging from 41 to $42 \mathrm{mg} / \mathrm{L}$. A maximum concentration of $42 \mathrm{mg} / \mathrm{L}$ and a median concentration of $42 \mathrm{mg} / \mathrm{L}$ were reported in 1972. Results from the base-flow sampling at the hot springs conducted in 2000 markedly were different. Silica concentrations were more variable, ranging from 40.8 to $46.9 \mathrm{mg} / \mathrm{L}$ and exhibited a median value of 44.9 $\mathrm{mg} / \mathrm{L}$. Comparison of calcium and sulfate results shows that samples collected during the 2000 base-flow sampling event exhibited dissolved calcium concentrations ranging from 38.9 to $47.9 \mathrm{mg} / \mathrm{L}$ and dissolved sulfate concentrations ranging from 7.0 to $7.5 \mathrm{mg} / \mathrm{L}$ as compared with concentrations ranging from 44 to $45 \mathrm{mg} / \mathrm{L}$ and from 7.8 to $9.0 \mathrm{mg} / \mathrm{L}$, respectively as reported by Bedinger and others (1979).

Concentrations of 23 trace elements were measured in the base-flow samples (table 3). Trace element concentrations for 18 of the elements analyzed were less than MRL's for the hot-spring, base-flow samples. The trace elements having the highest concentrations in the hot springs were manganese (231 $\mu \mathrm{g} / \mathrm{L})$, barium $(141 \mu \mathrm{g} / \mathrm{L})$, and strontium $(110 \mu \mathrm{g} / \mathrm{L})$. The concentrations of trace elements in samples collected in 2001 are similar to the concentrations reported in Bedinger and others (1979).

Concentrations of 82 pesticides and semivolatile organic compounds (SVOC) were measured in base-flow samples collected at two hot springs (Springs 9 and 49) and one coldwater spring (ArScenic) (table 4, located at end of report). No concentration for any pesticide or SVOC exceeded its MRL. No pesticide or SVOC samples were collected for the Bedinger and others (1979) study.

Nine physical properties and bacteria concentrations were measured in hot-spring, base-flow samples (table 3). Total dissolved solids (TDS) concentration ranged from $177 \mathrm{mg} / \mathrm{L}$ to $207 \mathrm{mg} / \mathrm{L}$. The $\mathrm{pH}$ values ranged from 6.5 to 7.8 . Specific conductance ranged from $267 \mu \mathrm{S} / \mathrm{cm}$ to $296 \mu \mathrm{S} / \mathrm{cm}$. Water temperature ranged from $54.2^{\circ} \mathrm{C}$ to $63.7^{\circ} \mathrm{C}$. Alkalinity (as $\mathrm{CaCO}_{3}$ ) ranged from $118 \mathrm{mg} / \mathrm{L}$ to $128 \mathrm{mg} / \mathrm{L}$. Alkalinity (as $\mathrm{HCO}_{3}^{-}$) ranged from $144 \mathrm{mg} / \mathrm{L}$ to $156 \mathrm{mg} / \mathrm{L}$. Escherichia coli (E. coli) were detected in base-flow samples from Spring 8 (120 colonies/100 mL of water) and ArScenic spring (12 colonies/100 $\mathrm{mL}$ of water). Detections of fecal coliform indicator bacteria also were found at Spring 8 (200 colonies/100 mL of water) and ArScenic spring ( 74 colonies $/ 100 \mathrm{~mL}$ of water). Some physical property values for base-flow samples collected in 2000 vary slightly from values of samples collected in 1972 as reported by Bedinger and others (1979). Bedinger and others (1979, selected springs are shown in table 5, located at end of report) reported $\mathrm{pH}$ values ranging from 6.9 to 7.7 , specific conductance ranging from 266 to $276 \mu \mathrm{S} / \mathrm{cm}$, and TDS concentrations ranging from 184 to $189 \mathrm{mg} / \mathrm{L}$.

The alkalinity (as $\mathrm{HCO}_{3}^{-}$) concentrations reported by Bedinger and others (1979) for the hot springs differed considerably from those determined for base-flow samples in this study. The alkalinity (as $\mathrm{HCO}_{3}^{-}$) concentrations for the hot springs reported by Bedinger and others (1979) ranged from 155 to $165 \mathrm{mg} / \mathrm{L}$, whereas alkalinity (as $\mathrm{HCO}_{3}^{-}$) concentrations measured in the base-flow samples for 2000 and 2001 (table 3) ranged from 144 to $156 \mathrm{mg} / \mathrm{L}$. The difference might have been because of sampling differences, such as filtered water compared to whole water or difference in season and hydrologic conditions.

\section{Stormflow}

During stormflow conditions, nutrient, major ion, trace element, isotope, radiochemical, physical property, field measurement, and bacteria data were collected at nine hot springs and one cold spring. No constituents from the samples collected during stormflow exceeded their respective drinkingwater MCL's set by the U.S. Environmental Protection Agency (U.S. Environmental Protection Agency, 2003).

Concentrations of five nutrient compounds were measured in hot-spring, stormflow samples (table 3). The concentrations generally were less than $0.5 \mathrm{mg} / \mathrm{L}$ and concentrations in many samples were below the MRL for the compound. The concentrations of two nitrogen and one phosphorus compound were low-values for all the analyses were less than $1 \mathrm{mg} / \mathrm{L}$ and concentrations in most samples were below the MRL for the compound.

Concentrations of eight major ions were measured in hot-spring stormflow samples (table 3 ). Concentrations were less than MRL's for samples analyzed for potassium, sodium, chloride, and fluoride. The constituents having the highest concentrations in the hot springs were calcium $(41.9 \mathrm{mg} / \mathrm{L})$ and silica $(38.7 \mathrm{mg} / \mathrm{L})$.

Concentrations of 23 trace elements were measured in hot-spring, stormflow samples (table 3 ). Concentrations were less than MRL's for samples analyzed for 16 trace elements. The trace elements having the highest concentrations in the hot springs were manganese $(261 \mu \mathrm{g} / \mathrm{L})$, iron $(208 \mu \mathrm{g} / \mathrm{L})$, and barium $(156 \mu \mathrm{g} / \mathrm{L})$.

Concentrations of 82 pesticides and SVOC's were measured in stormflow samples collected at two hot springs (Springs 9 and 49) and one cold spring (Happy Hollow) (table 4). No concentration for any pesticide or SVOC exceeded its MRL.

Nine physical properties and field measurements and bacteria concentrations were measured in hot-spring stormflow samples. Values and summary statistics of these measurements are shown in table 3. Most values are similar to their baseflow counterparts. Detections of E. coli bacteria were found in the sample from Spring 33 ( 25 colonies/100 mL of water). Additional samples would be required for comparison with the MCL for total coliform bacteria (including fecal coliform and $E$. coli) set at more than 5 percent samples total coliformpositive in a month (U.S. Environmental Protection Agency, 2003). A possible source of the bacteria was runoff from the hillside above spring 33. No detections of fecal coliform indicator bacteria were found in the stormflow samples. 


\section{Water Temperature of the Springs}

As one of the fundamental water-quality characteristics and the characteristic of primary interest for this resource, a long history of temperature data exists for the hot springs. The first recorded measurement of water temperature for the hot springs at HSNP was made by William Dunbar and George Hunter for a scientific investigation requested by President Thomas Jefferson in 1804; a maximum spring temperature of $67.8^{\circ} \mathrm{C}$ was measured during this study (Weed, 1902). Owen (1860) reported a maximum temperature of $64.4^{\circ} \mathrm{C}$. The same year, Glascow (1860) reported a maximum temperature of $65.6^{\circ} \mathrm{C}$. Bedinger and others (1979) measured a maximum temperature of $61.8^{\circ} \mathrm{C}$ (Spring 49) in 1972. The maximum temperature for the current study, measured in conjunction with the collection of the water-quality samples during base flow, was $63.7^{\circ} \mathrm{C}$ (Springs 9 and 25). Temperatures for springs that have water-temperature measurements from several previous studies are listed in table 6.

Water-temperature data at the hot springs do not indicate long-term change in temperature through time, perhaps with the exception of Spring 42. Bedinger and others (1979) calculated a slight decrease in maximum water temperature $\left(0.6^{\circ} \mathrm{C}\right.$ per 10 years $)$ in 12 hot springs measured between 1890 and 1952 in comparison with water temperatures measured in 1952 (table 6; Kuroda, 1953), but noted that the data did not necessarily support the existence of a trend "because of differences in sampling points, variations in temperature with flow rates, and variations in temperatures owing to air temperature." The factors controlling final temperature of the hot waters at the discharge points, for example air temperature, engineered spring collection and routing infrastructure, and short flow path cold-water recharge contribution, are variable and make direct comparison of temperature measurements difficult.

Water temperature was measured continuously (3-minute intervals) during the current study between August 2000 and October 2002 at four hot springs (Springs 8, 17, 25, and 46) and one cold spring (Happy Hollow); a single-point measurement was taken at all sampled springs as part of the base-flow and stormflow sampling events. The continuous water-temperature data collected for the current study are the first and only data of this type available for the Hot Springs system.

Base flow (excludes "storm events") water temperatures (fig. 3) between August 2000 and June 2005 for the continuously measured springs typically ranged from about $63.0^{\circ} \mathrm{C}$ to $63.5^{\circ} \mathrm{C}$ (Spring 25 ), $60.0^{\circ} \mathrm{C}$ to $62.0^{\circ} \mathrm{C}$ (Spring 8), $54.5^{\circ} \mathrm{C}$ to $57.0^{\circ} \mathrm{C}$ (Spring 46 ), and $54.0^{\circ} \mathrm{C}$ to $54.5^{\circ} \mathrm{C}$ (Spring 17). The higher temperatures for these four springs generally occurred during the summer months and the lower temperatures (for base-flow conditions) occurred during the winter months; Spring 25 exhibits an offset delay of approximately 3 months potentially because of a deeper, more insulated flow path and minimal local, cold-water contribution. These data, similar to data presented in previous investigations, indicate that seasonal temperature fluctuations of the springs are influenced by air temperature.

As hot waters move from depth to the surface discharge points at the springs, some decrease in the maximum temperatures attained by these waters at depth may be expected. A technique for estimating water temperature at depth is to use silica concentration as a chemical thermometer (Fournier and Rowe, 1966). The silica concentration of water discharging at

Table 6. Temperature of selected hot springs.

[modified after Bedinger and others (1979); units in degrees Celsius]

\begin{tabular}{lccccccc}
\hline & \multicolumn{7}{c}{ Year of measurement } \\
\cline { 2 - 7 } \multicolumn{1}{c}{ Site name } & $\mathbf{1 8 9 0}^{\mathbf{1}}$ & $\mathbf{1 9 0 0}^{\mathbf{2}}$ & $\mathbf{1 9 0 1}^{\mathbf{2}}$ & $\mathbf{1 9 3 1}^{\mathbf{3}}$ & $\mathbf{1 9 5 2}^{\mathbf{4}}$ & $\mathbf{1 9 7 2}^{\mathbf{5}}$ & $\mathbf{2 0 0 0}$ \\
\hline Spring 1 & 62.6 & 61.9 & 61.7 & -- & 62.0 & 54.6 & -- \\
Spring 17 & -- & 55.4 & 56.4 & 55.6 & 56.9 & 56.0 & 54.2 \\
Spring 23 & -- & 62.0 & 62.4 & 50.0 & 59.6 & 56.2 & - \\
Spring 42 (Quapaw bathhouse) & 51.6 & -- & 58.3 & 60.6 & 60.8 & 61.3 & 61.9 \\
Spring 46 (Fordyce bathhouse) & -- & 51.5 & -- & 57.2 & -- & 58.3 & 55.7 \\
\hline
\end{tabular}

${ }^{1}$ Branner, 1892.

${ }^{2}$ Haywood, 1902.

${ }^{3}$ Hamilton, 1932.

${ }^{4}$ Kuroda, 1953.

${ }^{5}$ Bedinger and others, 1979. 


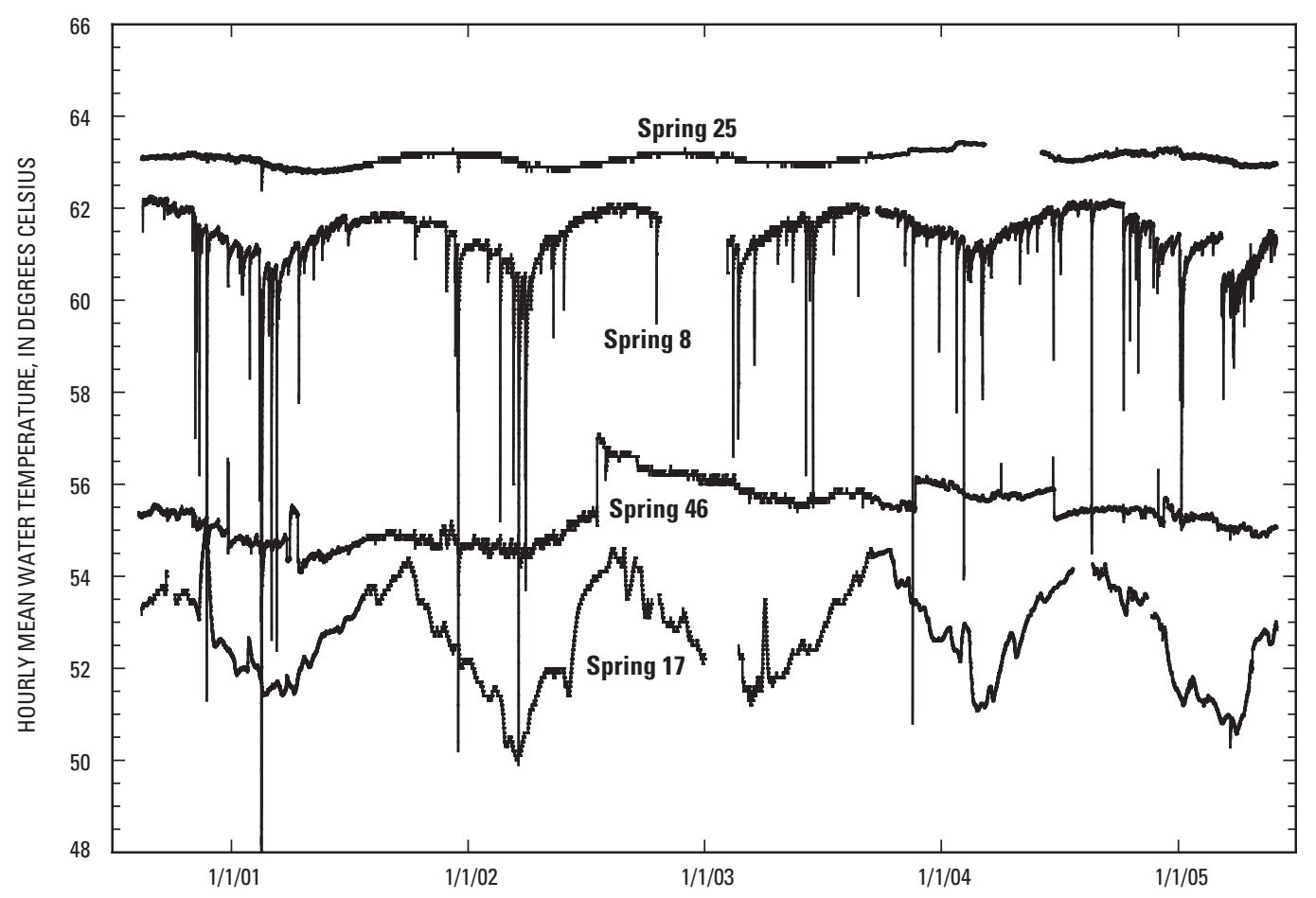

Figure 3. Water temperature at hot springs equipped with continuous recorders.

the surface can be used to determine the subsurface temperature of the water when it was last at equilibrium with solid siliceous phases. Silica minerals exhibit increased solubility at higher temperatures. While dissolution of silica occurs at a relatively rapid rate, precipitation induced by any decrease in temperature is kinetically inhibited and often occurs more slowly from a resultant supersaturated solution. As the hot waters at HSNP move towards the surface and begin cooling, original silica concentrations are maintained, and the waters become supersaturated at the new, lower temperature. The degree of supersaturation can be used to calculate the maximum temperature that the water has attained on its flow path. The assumptions used for this method of estimating maximum water temperature are (1) that the water reached thermal dynamic equilibrium with respect to dissolved silica and the parent mineral phases, (2) the parent mineral phase for hot springs flow system was chalcedony (a cryptocrystalline quartz mineral composing the primary mineralogy of the Bigfork Chert and Arkansas Novaculite), and (3) no substantial amount of silicate precipitation occurred in the water before sampling at the hot spring sources.

Samples collected in 1972 (Bedinger and others, 1979) for the most part have silica concentrations that are between the values for base-flow and stormflow samples collected in September 2000 and October 2001; the concentrations for the samples collected in 1972 are closer to the 2000 base-flow values than to the 2001 stormflow values (table 5). The samples collected in January 1972 were collected following precipitation conditions that were similar to the precipitation conditions preceding the collection of base-flow samples collected in September 2000.

The higher average silica concentrations for the samples collected during base flow in 2000 indicate that the maximum temperature of the water traveling on the deep flow path may be higher than previously calculated. Bedinger and others (1979) used the approach of Fournier and Rowe (1966) to calculate the maximum temperature reached by the water. The same calculation and assumption of aquifer composition predominated by chalcedony were used with silica data from the base-flow samples collected in 2000. These estimated temperatures are the result of mixtures of waters from different depths and flow paths and of different temperatures. Based on the maximum silica concentration from base-flow data collected in 2000 (seen at spring 47 , table 3 ), the maximum temperature is approximately $66.6^{\circ} \mathrm{C}$. This temperature is $3.4^{\circ} \mathrm{C}$ higher than the source temperature of $63.2^{\circ} \mathrm{C}$ (based on a silica concentration of $41.5 \mathrm{mg} / \mathrm{L}$ ) calculated by Bedinger. This difference is potentially explained by the timing of the sampling in 1972 (Bedinger and others, 1979): hot-spring samples were collected during January, when shallow groundwater levels usually are highest and short-flow path recharge having low-silica concentrations should be expected to be a more important component of total flow than during summer, when shallow ground-water levels are lowest, and therefore the high-silica thermal water has a larger impact. This conclusion is supported by stormflow silica concentration data collected in 2001. During the stormflow sampling (a time 
when short-flow path recharge is greatest), the median silica concentration was $8.6 \mathrm{mg} / \mathrm{L}$ less than during the base-flow sampling (table 3, fig. 4).

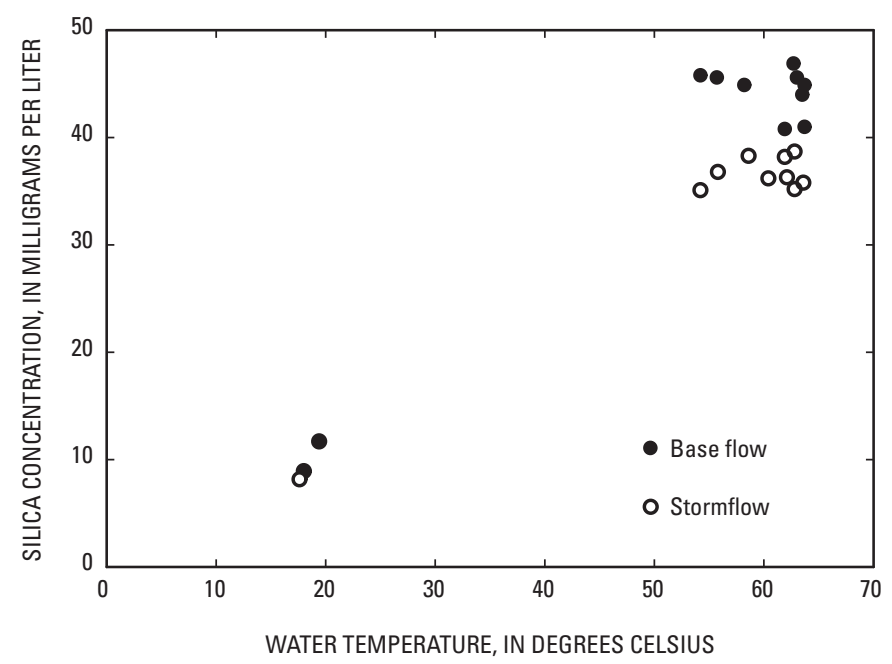

Figure 4. Relation between silica concentration and water temperature.

\section{Influence of Locally Derived Recharge on the Water Quality and Temperature of Springs}

Water-quality, water-temperature, isotopic, and radiochemical data can help assess the influence of locally derived recharge on water quality of the hot springs by providing information on the degree of mixing between deep flow-path, hot-water recharge and shallow flow-path, cold-water recharge in the discharge area.

\section{Water-Quality Data}

Water-quality data show substantial differences in water chemistry of the springs during base-flow and stormflow conditions; that is, all the springs sampled indicated some measure of influence from local recharge. Of particular note are the results of statistical tests (t-test and rank sum test) that indicate statistically significant differences ( $\mathrm{p}$-values less than 0.05 ) between the median values of base-flow and stormflow samples for several constituents and physical properties: silica, TDS, strontium, sulfate, and barium (table 7). While variations in these constituents and physical properties do not adversely affect water quality, the differences do provide evidence of variability in the factors controlling water quality of the hot springs and show that water quality is influenced by the locally derived, cold-water component of flow path to the springs. This younger, locally derived component of flow is possibly susceptible to surface influences associated with urbanization and changing land use that might introduce contaminants into the thermal springs and thereby degrade the quality of the resource.

Table 7. Summary of statistical tests for selected constituents and physical property differences between base-flow and stormflow samples.

[Tests are based on data from tables 3 and 5]

\begin{tabular}{lll}
\hline \multicolumn{1}{c}{$\begin{array}{c}\text { Constituent/physical } \\
\text { property }\end{array}$} & p-value & Type of test \\
\hline Silica, total & 0.001 & t-test \\
Total dissolved solids & 0.006 & t-test \\
Strontium, total & 0.001 & rank sum \\
Sulfate, dissolved & 0.024 & rank sum \\
Barium, total & 0.038 & rank sum \\
\hline
\end{tabular}

Silica concentrations can be used to estimate contribution of cold-water recharge to the springs during base-flow and stormflow conditions. As previously discussed, silica is at saturated conditions along the hot-water flow path; because of this silica should behave as a relatively conservative species. This combined with the considerable difference in silica concentration for hot water and cold water makes silica an excellent tracer for mixing calculations. Estimated cold-water contributions to springs during stormflow were calculated using a binary mixing model and assumed values for coldand hot-water end-member silica concentrations. The mean silica concentration value for the cold-water springs and wells measured during this study and the study of Bedinger and others (1979) was about $8 \mathrm{mg} / \mathrm{L}$. Silica concentrations of the deep flow-path hot waters are markedly different, exhibiting a maximum of about $47 \mathrm{mg} / \mathrm{L}$. These values were used in the mixing model. Error inherent in the estimate calculations derives from these estimated cold-water and hot-water end-member silica concentrations; however, the values are relatively well constrained. An empirical understanding of the sensitivity of the calculation to error in the end-member values is illustrated by the fact that a $1 \mathrm{mg} / \mathrm{L}$ variance in the end-member results in an approximate change of 2 percent in the estimated cold-water contribution. Thus, the estimate is sensitive to this constituent, but, within the constraints of silica variation at individual springs, the result is still useful and informative-providing strong evidence of considerable contribution of shallow flow-path cold water to the hot springs. Estimated contribution of cold-water recharge to the hot springs during base-flow conditions varies from 0 to 16 percent (table 8). Estimated contribution of cold-water recharge to the hot springs during stormflow conditions varies from 21 to 31 percent. 
Table 8. Cold-water fraction estimates calculated from silica and total dissolved solids data for base-flow and stormflow conditions.

\begin{tabular}{|c|c|c|c|c|c|}
\hline \multirow[t]{2}{*}{ Spring } & \multirow{2}{*}{$\begin{array}{l}\text { Type of } \\
\text { spring }\end{array}$} & \multicolumn{2}{|c|}{$\begin{array}{l}\text { Silica-based cold- } \\
\text { water fraction }\end{array}$} & \multicolumn{2}{|c|}{$\begin{array}{l}\text { Total dissolved solids based } \\
\text { cold-water fraction }\end{array}$} \\
\hline & & Base flow & Stormflow & Base flow & Stormflow \\
\hline Happy Hollow & Cold & 0.98 & 1.00 & 0.99 & 1.00 \\
\hline Spring 17 & Hot & 0.03 & 0.31 & 0.16 & 0.18 \\
\hline Spring 46 & Hot & 0.04 & 0.26 & 0.05 & 0.15 \\
\hline Spring 33 & Hot & 0.05 & 0.22 & 0.07 & 0.10 \\
\hline Spring 49 & Hot & 0.08 & 0.28 & 0.07 & 0.11 \\
\hline Spring 8 & Hot & 0.04 & 0.23 & 0.12 & 0.14 \\
\hline Spring 42 & Hot & 0.16 & 0.27 & 0.07 & 0.13 \\
\hline Spring 47 & Hot & 0.00 & 0.21 & 0.12 & 0.17 \\
\hline Spring 9 & Hot & 0.05 & 0.30 & 0.08 & 0.13 \\
\hline Spring 25 & Hot & 0.15 & 0.29 & 0.00 & 0.13 \\
\hline
\end{tabular}

Total dissolved solids (TDS) is determined by weighing the residue left from a water sample upon evaporation and provides a quantitative measurement of all non-volatile dissolved species in solution. TDS is not a conservative measurement as it changes with any precipitation or dissolution reactions as rock-water interaction occurs; however, TDS is a robust measurement that changes considerably only upon precipitation or dissolution of solids or with mixing of different water sources with markedly differing TDS values. As such, when other geochemical factors influencing precipitation/dissolution reactions are expected to remain relatively constant, TDS can serve as a valuable indicator of mixing. A comparison of geochemical conditions during base-flow and stormflow sampling events shows no indication of varying effects on precipitation or dissolution, so the main controlling factor may be expected to be the varying input of cold-water recharge.

TDS concentrations also can be used to estimate contribution of cold-water recharge to the springs during base-flow and stormflow conditions. TDS concentrations for shallow flowpath waters in HSNP typically are about $20 \mathrm{mg} / \mathrm{L}$ as observed for cold water springs and wells. TDS concentrations for deep flow-path waters are different markedly, about $207 \mathrm{mg} / \mathrm{L}$ (the maximum hot spring TDS concentration measured). Assuming these as representative of the hot and cold TDS end members, and applying a simple, binary mixing model, estimated contribution of cold-water recharge to the hot springs during base-flow conditions varies from 0 percent (Spring 25) to 16 percent (Spring 17) for individual springs (table 8). Estimated contribution of cold-water recharge to the hot springs during storm conditions varies from 10 (Spring 33) to 18 percent (Spring 17).

\section{Water-Temperature Data}

The continuous (3-minute interval) water-temperature data collected at Springs 8, 17, 25, and 46 are useful for showing relations between water temperature, local recharge, and storm events. Water temperature of springs varies seasonally, although water temperature also fluctuates rapidly in response to mixing of hot-springs water with locally derived recharge after storms. The decrease in water temperature resulting from specific storms has a non-linear relation with the amounts of precipitation associated with the storm events; response time for onset of water temperature decrease after a storm event is highly variable.

In addition to seasonal fluctuations, short-term fluctuations in water temperature occur (fig. 3) as a result of mixing of hot-springs water with locally derived recharge after a storm (note the downward "troughs" especially prominent for Spring 8, in figure 3). The relation between water temperature decreases and amount of precipitation associated with a specific storm event is non-linear. For example, storms with less than about 1.5 inches of precipitation resulted in temperature decreases of $0.5^{\circ} \mathrm{C}$ or less at Spring 46 (fig. 5). Storms with greater than about 1.5 inches of precipitation resulted in highly variable decreases in water temperature at Spring 46: a storm with 1.8 inches of precipitation caused a $2.7^{\circ} \mathrm{C}$ decrease in water temperature, but a storm with 2.4 inches of precipitation caused only a $0.26{ }^{\circ} \mathrm{C}$ decrease in water temperature. Data for Springs 8, 17, and 25 exhibited similar behavior. The variability of the water-temperature fluctuation is probably related to a combination of antecedent soil saturation conditions and the intensity, duration, and areal distribution of precipitation during the event. 


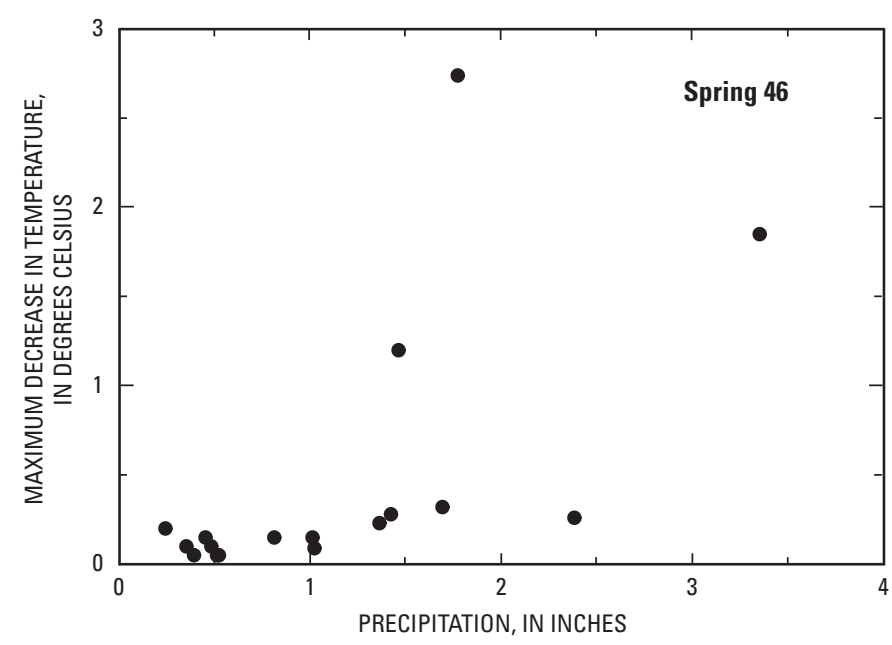

Figure 5. Relation between water temperature decreases and precipitation at Spring 46.

The response time for the water temperature at Springs 8, 17,25 , and 46 to begin decreasing from the baseline temperature as a result of recharge from storms in 2000 and 2001 was highly variable. Storm-event, start-time data from automated rain gages indicated that water temperature at Spring 25 and Spring 46 began decreasing from their baseline temperature as quickly as 1 hour after the beginning of a storm event. The minimum response time for water temperature at Spring 8 was 4 hours and at Spring 17 the minimum response time was 8 hours.
The water temperature of the springs shows a relation to discharge. Figure 6 presents composited discharge and temperature data for the period of record at the spring reservoir. Water from springs 8, 9, 17, 25, 42, 46, 47, 49 and 25 other springs flows into the spring reservoir (Yeatts, 2006). Figure 7 more closely illustrates the relation of temperature and discharge. Rapid increases or "spikes" in amount of discharge measured at the HSNP spring reservoir were related to decreases in temperature of the water flowing into the reservoir. This would indicate that thermal-water input to total spring discharge is relatively constant, but that increased coldwater input occurs during storm events. Bedinger and others (1979) offered an alternative hypothesis and stated that there should be an increase in hot-spring temperature with increasing spring discharge (apparently assuming increased discharge is from hot-water recharge). However, the more recent data indicate that, in terms of total discharge from the springs, the opposite relation is observed. Any time that the hot-water component of discharge to the springs increases, an increase in temperature may be expected because of the increased convection/conduction ratio (that is a greater mass of water carrying a proportionally greater heat load passes through an unchanging volume of rock with an unchanged conduction and heat capacity) and the resultant smaller proportional loss of thermal energy to the environment of the discharge area. Flow and temperature data collected at the spring reservoir indicate that temperature decreases as discharge increases. This relation is evidence that discharge increases are attributable to increases in the short-flow path, cold-water flow component. Data indicate that the hot-water component of discharge is

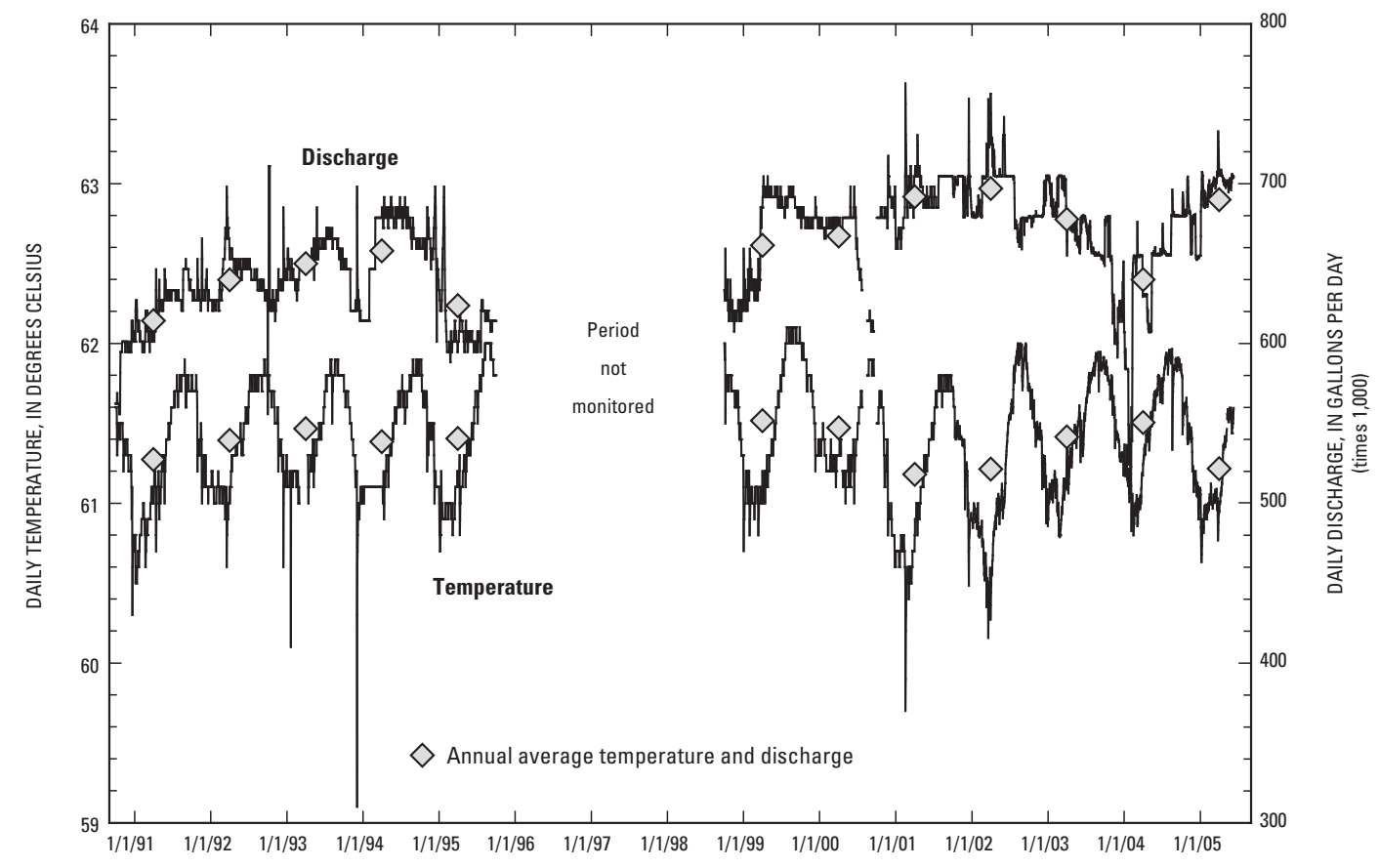

Figure 6. Relation between discharge and water-temperature data at the Hot Springs National Park spring reservoir, showing the period of record —water years 1991 through 2005. 

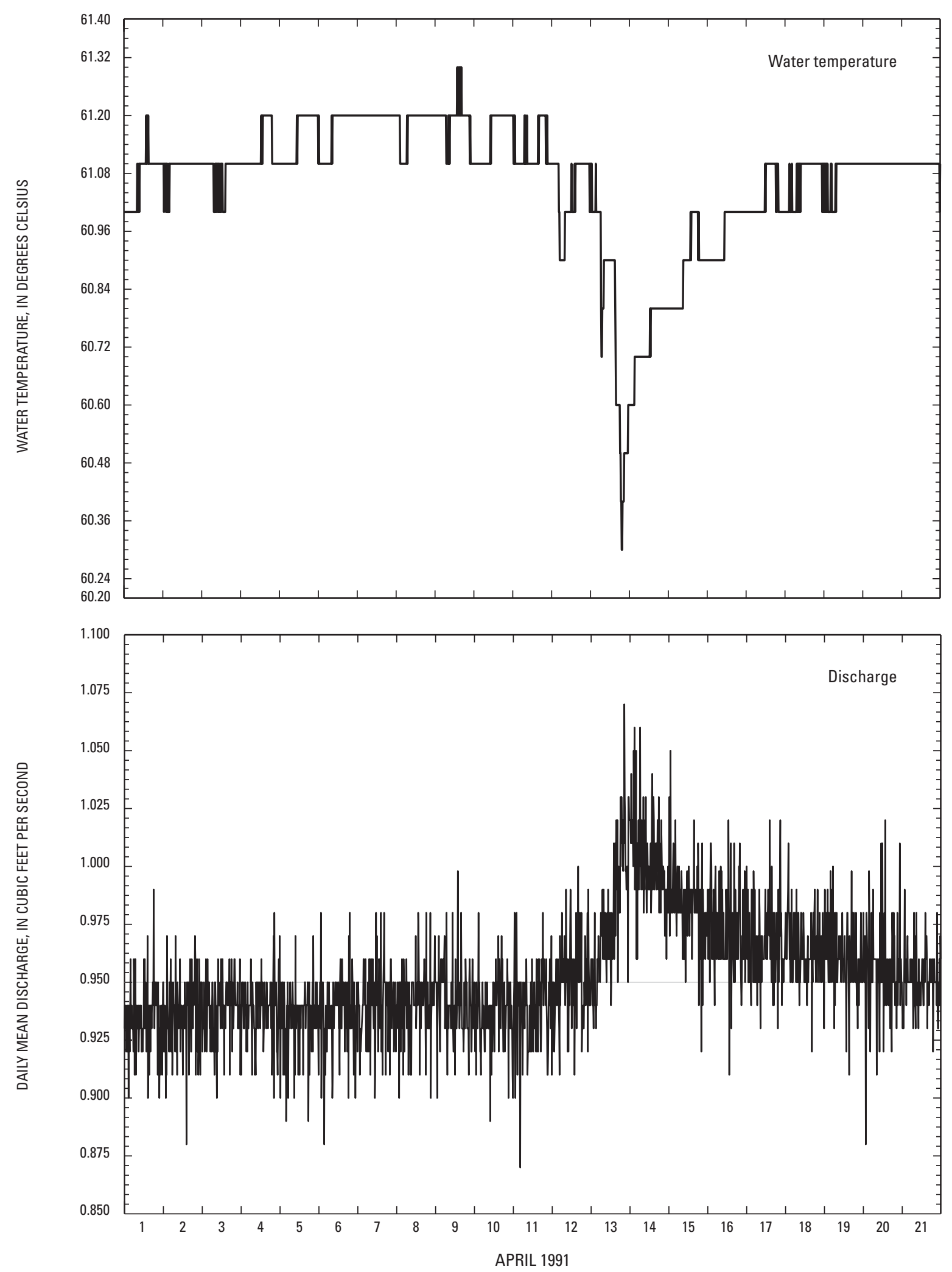

Figure 7. Relation between discharge and water-temperature data at the Hot Springs National Park spring reservoir, April 1991. 
relatively stable; no changes in spring temperature that might be ascribed to changing hot water input have been observed.

Temperatures for shallow flow-path cold water are markedly different than long-flow-path hot water. Temperatures for shallow flow-path cold water (for example, Happy Hollow spring) typically are about $17^{\circ} \mathrm{C}$ (near mean annual temperature). Temperatures for deep flow-path hot water (springs 8, 17,25 , and 46) range from $54.2^{\circ} \mathrm{C}$ to $63.7^{\circ} \mathrm{C}$, depending on the spring and whether the temperature was a base-flow or stormflow measurement. The effects of storms on water temperature appear to be greatest at Spring 8, although some effects are apparent in the other three hot springs instrumented for continuous temperature monitoring (fig. 3).

Estimated cold-water contribution to springs during stormflow were calculated using a binary mixing model and assumed values for cold- and hot-water temperatures. To ensure a conservative estimate of cold-water contribution from these calculations, the (likely erroneously conservative) assumption was made that there was zero cold-water input during the maximum temperature base-flow period observed during monitoring at the spring. Hence, the calculated estimates for cold-water contribution would actually be additive-applied to any cold-water input at base flow. Error inherent in the estimate calculation derives from these estimated temperaturesthe cold-water temperature estimate is well constrained, and the hot-water estimate is reasonably well constrained but probably includes more error. An empirical understanding of the sensitivity of the calculation to error in the hot-water temperature is illustrated by the fact that a 2 degree variance in the temperature results in a 3 to 4 percent change in the estimated cold-water contribution. Thus, the estimate is sensitive to temperature, but, within the constraints of temperature variation at individual springs, the result is still useful and informative. For the continuously monitored springs, the maximum calculated estimate for cold-water inputs using these criteria were: 35 percent for Spring 8, 30 percent for Spring 17, 5 percent for Spring 46, and 1 percent for Spring 25. It is interesting to note the temperature measurements taken in conjunction with stormflow sampling ranged from 0 to 7 percent and yielded a median result of 0.1 percent. This illustrates the variability from storm to storm and from spring to spring in cold-water input and suggests that while geochemical data derived from the sampling event for this study do provide evidence of coldwater influence, the particular time chosen for sampling was certainly not a time of maximum cold-water contribution for most of the springs.

Water temperature and discharge at the spring reservoir were measured continually for most of the period from October 1990 through September 2001 (figs. 6 and 7). These data represent a composited value for temperature from all of the collected springs (springs 8, 9, 17, 25, 42, 46, 47, 49 and 25 other springs); the temperature data are skewed to slightly lower temperature because of loss of thermal energy during transit from the spring discharge points through the collection system to the reservoir. The average temperature at the reser- voir is about $61.2{ }^{\circ} \mathrm{C}$; strong seasonal and diurnal variations are apparent. No cold-water springs are routed to the reservoir.

These composited reservoir data also indicate changes in discharge and temperature in response to storms. Analysis of these data can provide information about gross spring response to storms and about the total cold-water component of recharge to the springs associated with storms. Inspection of reservoir temperature data shows six or more storms each year during the period of record that result in a discernible decrease in temperature indicating a considerable cold-water recharge component to total thermal spring flow. Using the same mixing model approach for the reservoir as was used for individual springs temperature data (equation 1) an estimate of the quantity of cold water contributed can be derived. For example, a mid-April 1991 storm resulted in increased total flow from the springs and a decrease in composite spring temperature in the spring reservoir (fig. 7). A temperature decrease of about $0.8{ }^{\circ} \mathrm{C}$ was recorded; assuming an average cold-water temperature of $17^{\circ} \mathrm{C}$, this would indicate an estimated additional 2 percent cold-water contribution to the hot springs. Numerous such decreases in temperature are noted during the period of record, ranging up to a 25 percent coldwater contribution.

\section{Isotopic and Radiochemical Data}

Isotopic concentrations frequently can be used to determine sources of water for a spring because of the unique isotopic concentrations in the recharge sources. Most elements (including hydrogen, oxygen, carbon, sulfur, and strontium discussed below) occur naturally as mixtures of two or more isotopes. All the isotopes of an element exhibit the same chemical properties; however, different chemical, physical, or biological processes can influence the abundance of each isotope that is present in a particular sample (Hem, 1985).

Stable isotopes are measured as the ratio of the two most abundant isotopes of a given element. For oxygen, the ratio is ${ }^{18} \mathrm{O} /{ }^{16} \mathrm{O}$. The relative abundance of the oxygen isotopes can be expressed as a deviation from a standard quantity using delta ( $\delta$ ) notation and symbolized as $\delta^{18} \mathrm{O}$; values are expressed in per mil $(\%)$ :

$$
\delta^{18} O_{x}=\left(R_{x}-R_{s t d}\right) / R_{s t d} \times 1000
$$

where

$$
\begin{aligned}
& \delta^{18} O_{x} \text { is the } \delta \text { value of a sample } x, \\
& R_{x} \text { is the }{ }^{18} \mathrm{O} /{ }^{16} \mathrm{O} \text { ratio of that sample, and } \\
& R_{\text {std }} \text { is the }{ }^{18} \mathrm{O} /{ }^{16} \mathrm{O} \text { ratio of the standard. }
\end{aligned}
$$

A positive value of $\delta^{18} \mathrm{O}$ represents water with more ${ }^{18} \mathrm{O}$ relative to ${ }^{16} \mathrm{O}$ than the standard water, Vienna Standard Mean Ocean Water (VSMOW) described by Gonfiantini (1978). A zero value of $\delta^{18} \mathrm{O}$ represents water that has the same ratio of ${ }^{18} \mathrm{O}$ to ${ }^{16} \mathrm{O}$ as VSMOW. A negative value of $\delta^{18} \mathrm{O}$ represents water with less ${ }^{18} \mathrm{O}$ relative to ${ }^{16} \mathrm{O}$ than VSMOW. Similar 
notation is used to express the concentrations of the stable isotopes of hydrogen (deuterium/protium, $\delta \mathrm{D}$ ) also referenced to VSMOW, carbon $\left({ }^{13} \mathrm{C} /{ }^{12} \mathrm{C}\right)$ referenced to the Pee Dee Belemnite (PDB), and sulfur isotopes $\left({ }^{34} \mathrm{~S} /{ }^{32} \mathrm{~S}\right)$ referenced to the Canyon Diablo Troilite (Hoefs, 1987).

Concentrations of $\delta^{18} \mathrm{O}$ and $\delta \mathrm{D}$ do not indicate substantial differences in water chemistry of the springs during base-flow and stormflow conditions. Stormflow $\delta^{18} \mathrm{O}$ and $\delta \mathrm{D}$ values are statistically indistinguishable from base-flow values; however, stormflow $\delta \mathrm{D}$ values exhibit a slightly lower mean $(-30.0 \%$ o compared to $-29.0 \%$ for base flow) tending to plot below the base-flow values (fig. 8). Cold-water sample $(\delta \mathrm{D})$ values also are low at $-31.9 \%$ (Happy Hollow) and $-28.1 \%$ (ArScenic). Oxygen and hydrogen isotopic data do not enable characterization of cold-water recharge to the hot springs. Hot-spring $\delta \mathrm{D}$ and $\delta^{18} \mathrm{O}$ values are similar to local precipitation and shallow ground water; the data corroborate the conclusion of Bedinger and others (1979) that the hot springs are recharged locally with no evidence of meteoric water from outside the region being contributed to the hot springs.

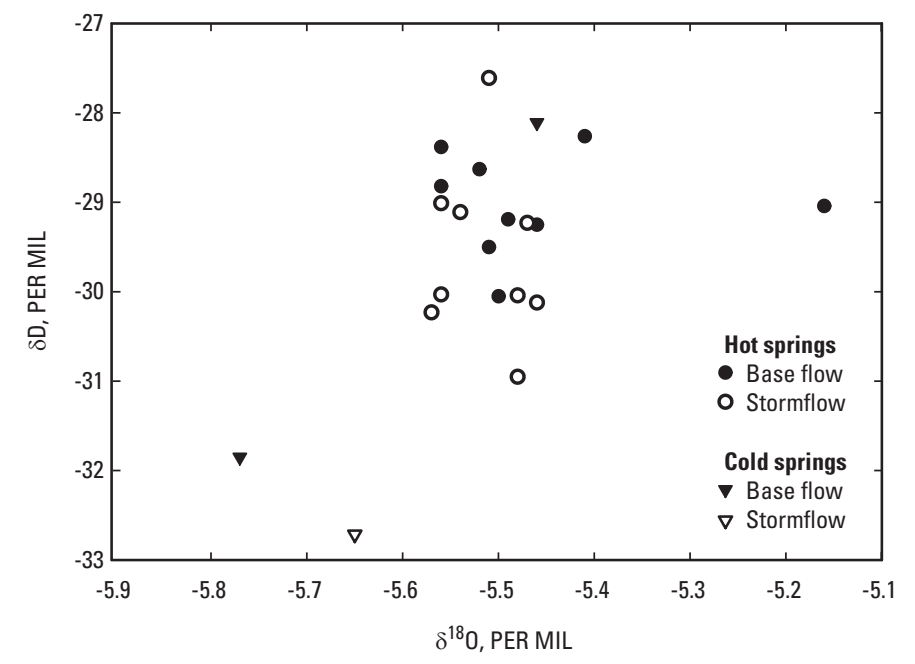

Figure 8. Relation between deuterium/hydrogen and oxygen-18/ oxygen-16 isotopic ratios.

Concentrations of $\delta^{13} \mathrm{C}$ do not indicate substantial differences in water chemistry of the springs during base-flow and stormflow conditions. Stormflow $\delta^{13} \mathrm{C}$ values statistically are indistinguishable from base-flow values. Carbon isotope data indicate that a large component of dissolved inorganic carbon was ultimately derived from mineralization of organic carbon in recharge-zone soils. Fractionation that occurs during photosynthesis causes incorporation of isotopically light carbon in plant tissue with $\delta^{13} \mathrm{C}$ values typically ranging from -10\%o to $-30 \%$, depending on the vegetation type (Boutton and others, 1980; Deines, 1980). The degree of fractionation depends upon the photosynthetic pathway used by given groups of plants. The predominant photosynthetic pathways are the $\mathrm{C} 3$ and $\mathrm{C} 4$ pathways, so called because of the length of certain carbon chains employed in photosynthesis. The C3 pathway is the most ancient and most common, operating in 85 percent of plant species. Most $\mathrm{C} 3$ plants have $\delta^{13} \mathrm{C}$ values averaging about $-27 \%$ o. C3 plants dominate in tropical, subtropical, and temperate forests. The $\mathrm{C} 4$ pathway is a geologically recent development that occurred as a plant response to dropping atmospheric $\mathrm{CO}_{2}$ concentrations in the early Tertiary. The $\mathrm{C} 4$ pathway is a more efficient photosynthetic process and enables plants to thrive in hot and arid conditions. $\mathrm{C} 4$ plants have a mean $\delta^{13} \mathrm{C}$ of about $-12.5 \%$ o. $\mathrm{C} 4$ plant species represent only about 5 percent of terrestrial species; however, they dominate hot and arid ecosystems, including tropical, subtropical, and temperate grasslands. Degradation of vegetation in soils contributes soil gas $\mathrm{CO}_{2}$ to soil pore space, and the light carbon isotopic composition of the parent organic matter is conveyed to the $\mathrm{CO}_{2}$ daughter product as soil carbon is oxidized. As ground water infiltrates, soil $\mathrm{CO}_{2}$ is brought into solution forming four main species of dissolved inorganic carbon: $\mathrm{CO}_{2}$ (aqueous), carbonic acid, bicarbonate, and carbonate. Bicarbonate is the predominant species at typical ground-water $\mathrm{pH}$ values ( $\mathrm{pH} 6$ through 10). These carbon species retain the carbon isotopic signature of the parent material. Ground water also dissolves mineral carbonate material to contribute to dissolved inorganic carbon. Mineral carbonate typically has a relatively heavy $\delta^{13} \mathrm{C}$ value around $0 \%$ (Hoefs, 1987). Ground-water $\delta^{13} \mathrm{C}$ values will reflect the input of these two sources, usually having an intermediate value indicative of the relative contribution of the carbon types. Assuming an original soil $\mathrm{CO}_{2} \quad \delta^{13} \mathrm{C}$ value of $-26 \%$ as Bedinger and others (1979) used (based on a mean $\mathrm{C} 3$ photosynthetic plant $\delta^{13} \mathrm{C}$ value (Hoefs, 1987)) and a mineral carbonate value of $0 \%$, organic carbon contributed 52 to 55 percent of the total dissolved carbon present in base-flow and stormflow samples from the hot springs. Organic carbon contributed 87 percent of the total dissolved carbon present in Happy Hollow spring (cold water), which has water with very low bicarbonate content.

All stormflow samples from the hot springs were depleted in ${ }^{34} \mathrm{~S}$, whereas, the cold spring sample was enriched. The $\delta^{34} \mathrm{~S}$ of the stormflow samples for the hot springs ranged from $-5.65 \%$ at Spring 17 to $-4.96 \%$ at Spring 25 . The stormflow $\delta^{34} \mathrm{~S}$ for the cold-water Happy Hollow spring was $0.46 \%$. The differences in $\delta^{34} \mathrm{~S}$ may be attributable to two possible mechanisms: (1) differing sulfur sources for deep flow-path hot waters as compared with sources for the shallower flowpath cold waters. For example, weathering and dissolution of isotopically light sulfide minerals may be more prevalent for the hot-water flow path whereas dissolution of isotopically heavy sulfate minerals may be more prevalent for cold water, or (2) fractionation of dissolved sulfur species by sulfatereducing bacteria. Sulfate reduction typically results in preferential use of ${ }^{32} \mathrm{~S}$ for generation of sulfide species, resulting in enrichment of ${ }^{34} \mathrm{~S}$ residual dissolved sulfate (Krothe, 1983); this is the opposite of what is observed for hot-spring samples, all of which are in the negative $\delta^{34} \mathrm{~S}$ range, thereby making the first mechanism the more likely for hot springs water.

Sulfur isotopic composition of the two cold-water spring samples are markedly different from the hot springs. $\delta^{34} \mathrm{~S}$ values for Happy Hollow spring and ArScenic spring were $0.46 \%$ (stormflow) and $6.25 \%$ (base flow), respectively; these 
values are heavy relative to the thermal springs and are light relative to typical Ordovician to Mississippian-age rock sulfate $\delta^{34} \mathrm{~S}$ values (12\%o to $29 \%$ ) (Holser, 1977; Claypool and others, 1980 ). This could indicate that dissolution of isotopically heavy sulfate and/or microbially mediated isotopic fractionation are more important for the cold-water flow paths.

At HSNP, strontium concentrations of the stormflow samples were slightly, but significantly higher $(\mathrm{P}=0.001)$ than strontium of the base-flow samples (table 7; fig. 9). Plots of ${ }^{87} \mathrm{Sr} /{ }^{86} \mathrm{Sr}$ ratios and strontium concentration show that the stormflow samples for the hot springs plot primarily in the upper right area (high concentration-high ratio) of figure 9; base-flow samples are seen in the lower concentration area of the figure. Thus, strontium concentration data show a slight difference in base-flow and stormflow water chemistry for the springs. Interpretation of the cause of this phenomenon in view of cold-water recharge contribution is confounded by the existence of multiple strontium concentration populations in cold-water samples: (1) an end-member possibility with relatively high strontium concentrations and relatively low ${ }^{87} \mathrm{Sr} /{ }^{86} \mathrm{Sr}$ isotopic ratios, for example ArScenic spring with a concentration value of $135 \mu \mathrm{g} / \mathrm{L}$ and ratio of 0.7086 (fig. 9); and the Whittington Park well with a concentration of $260 \mu \mathrm{g} / \mathrm{L}$ and an unknown ratio (Bedinger and others, 1979), (2) an end-member possibility with relatively low strontium concentrations and ${ }^{87} \mathrm{Sr} /{ }^{86} \mathrm{Sr}$ ratios that are slightly higher than those seen in the hot springs, for example Happy Hollow Spring with a strontium concentration of $2.5 \mu \mathrm{g} / \mathrm{L}$ and ${ }^{87} \mathrm{Sr} /{ }^{86} \mathrm{Sr}$ ratio of 0.7129 (fig. 9) and the Sleepy Valley Spring with a strontium concentration of $10 \mu \mathrm{g} / \mathrm{L}$ and unknown isotopic value (Bedinger and others, 1979), and (3) an unsampled and therefore uncharacterized third end member possibility with relatively higher strontium concentrations and similar ${ }^{87} \mathrm{Sr} r{ }^{86} \mathrm{Sr}$ isotopic ratios. If mixing of the hot water component with one of these possible cold-water end-members is responsible for strontium chemistry in the hot springs, then for cold-water end-member possibility 1 , which has high concentration-low ratio, an increase in concentration and decrease in ratio for the resultant mix would be expected. In the case of mixing with cold-water end-member possibility 2 , which has low concentration-high ratio, a decrease in concentration and a slight increase in ${ }^{87} \mathrm{Sr} /{ }^{86} \mathrm{Sr}$ ratio would be expected. The third possible cold-water end member was not caught in the sampling regimen; this end member has a relatively high strontium concentration and $\mathrm{a}^{87} \mathrm{Sr} /{ }^{86} \mathrm{Sr}$ ratio that is comparable to that of the thermal waters. Applying a hyperbolic mixing model that incorporates terms for both concentration and isotopic composition (Faure and Mensing, 2005; Phillips and Koch, 2002) shows that end-member possibilities 1 and 2 are not feasiblemixing with these with the thermal waters will result in end compositions not observed for the stormflow samples (fig. 9). For end-member possibility 1 , consideration of concentration only (applying a binary mixing model and assuming thermal water strontium concentrations of $100 \mu \mathrm{g} / \mathrm{L}$ and cold-water concentrations of $200 \mu \mathrm{g} / \mathrm{L}$ - based on data from this study and from Bedinger (1979) - yields a range of possible mixtures with estimated cold-water contribution to hot spring discharge during storm events ranging from 8 to 17 percent; however, when the added dimension of isotope ratio is considered (applying a hyperbolic mixing model), the solution is shown as unfeasible (fig. 9); isotopic ratios measured are higher than would be predicted. For end-member possibility 2, neither concentration nor isotope ratio offers any feasible solution. The cold-water end-members possibilities 1 and 2 represented by Happy Hollow and ArScenic springs represent relatively old, deep flow-path cold waters. A possible cold-water contribution source not sampled during this study is the infiltration of precipitation and surface water through soils, regolith, and engineered and disturbed soils and other earth materials over and immediately surrounding the springs. The relatively rapid (but variable) temperature and geochemical response (seen in properties and constituents such as silica, TDS, and sulfate) of the hot springs to storm events indicates close connection with the surface and a short flow path. These data and the existence of this third end member may indicate that precipitation and stormflow water may be recharging within a few to several hundred feet of the spring discharge area, rapidly moving through the unsaturated zone to mix with deep flow-path hot waters, thereby impacting hot spring chemistry. Such a finding is of critical importance to the NPS because of the susceptibility of hot-spring water quality to activities occurring near the discharge area, including lawn, grounds, and facility maintenance; recreation and visitation; vehicle and machinery operation; occupation of and activities occurring within proximal buildings including the bath houses, the maintenance building, and the cooling facility.

Isotopic tracer data provide evidence of the influence of cold-water recharge on the hot springs. Tritium and ${ }^{35} \mathrm{~S}$ indicate the input of a small component of shallow flow-path, cold-water recharge to the hot springs; however, the small amounts of ${ }^{35} \mathrm{~S}$ present are within the analytical precision and do not allow a statistical comparison between base-flow and stormflow results or mixing calculations.

The 87-day half life of ${ }^{35} \mathrm{~S}$ makes it an effective tracer for studying processes that occur on a timescale of 1 year or less (Michel, 2000). Standard atmospheric precipitation has an approximate ${ }^{35} \mathrm{~S}$ concentration of $10 \mathrm{mBq} / \mathrm{L}$ (or greater). The low median values of ${ }^{35} \mathrm{~S}$ (less than $0.1 \mathrm{mBq} / \mathrm{L}$, eight of nine hot springs measured had ${ }^{35} \mathrm{~S}$ concentration below detection limits for base-flow samples) for the base-flow samples indicate recent recharge does not contribute substantially to base flow of the hot springs. Six out of eight stormflow samples exhibited detectable levels of ${ }^{35} \mathrm{~S}$ indicating that there is a small component of relatively young water in the hot springs; probably less than 1 year old. ${ }^{35} \mathrm{~S}$ concentrations in storm samples indicate that storm recharge is a component of hotspring discharge.

These water-temperature, water-quality, isotopic and radiochemical data do indicate the important influence of shallow flow-path, cold-water recharge on the chemistry of the hot springs. Water-quality, water-temperature, isotopic, and radiochemical data provide multiple lines of evidence 


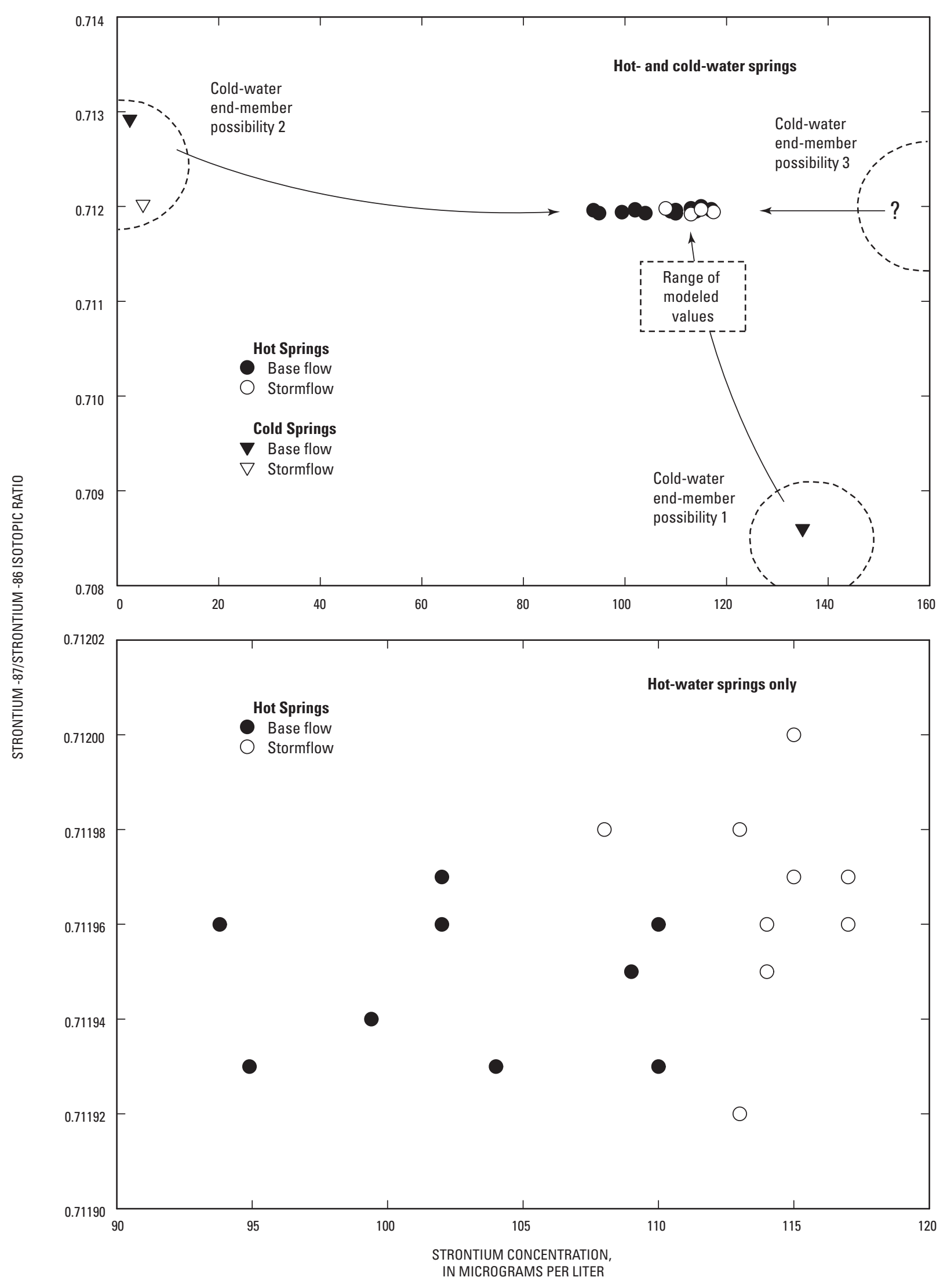

Figure 9. Relation between strontium-87/strontium-86 and strontium. 
supporting the importance of the contribution of cold-water recharge to hot springs. Binary mixing models using silica and TDS give relatively consistent results and indicate that coldwater recharge from stormflow contributes an estimated 10 to 31 percent of the flow of hot springs. Models using water temperature also give comparable results and indicate that cold-water recharge from stormflow contributes an estimated 1 to 35 percent of the flow of hot springs. Although these data indicate that cold-water recharge from stormflow does contribute to the flow of the hot springs, data from additional stormflow events and also from additional hot springs are needed to refine the contribution of cold-water recharge.

\section{Summary}

The hot springs of HSNP consist of a mixture of water from two sources: a primary source about 4,400 years old (hot water) and a secondary source less than 20 years old (cold water). Hydrologic conditions in the zone of dischargeincluding widespread distribution of fractures-enables integration of ground-water flow paths and mixing of the hot- and cold-water components of flow. Urbanization in the area near the hot springs has increased the potential for degradation of the quality of surface-water runoff and locally derived groundwater recharge to the springs. A previous study (Bedinger and others, 1979) indicated that a component of flow to some cold-water springs and wells in the vicinity of Hot Springs, Arkansas, showed evidence of contamination, such as elevated concentrations of nitrate and chloride, from localized recharge zones. Another work (C.S. Barks, U.S. Geological Survey, written commun., 1995) indicated that water from cold-water recharge areas might contribute 25 percent of the total flow to the hot springs during storms based on water temperature and flow data. This study verifies the existence and importance of the locally derived, cold-water component of water discharged by the hot springs.

Water samples were collected from springs in the study area in September 2000 and October 2001. Water samples were collected at nine hot springs and two cold-water springs in September 2000 during base-flow conditions. Nine hot springs and one cold-water spring were resampled in October 2001 after a storm event. Continuous temperature recorders were used to monitor the water temperature in four hot springs and one cold-water spring. The temperature monitors were activated in August 2000 and recorded water temperature continuously (at 3-minute intervals) through October 2002. Water samples were analyzed for a variety of dissolved chemical constituents (nutrients, major ions, trace elements, pesticides, semivolatile compounds, isotopes, and radiochemicals), physical properties, field measurements and bacteria. Knowledge of water chemistry can be used to interpret ground-water movement, source of the water, and temporal changes in chemical concentration. Comparison of sample analyses with the results from earlier studies dating back to the late 1800's shows that little change in major, minor, and trace constituent chemistry has occurred for base-flow conditions and the water continues to have excellent quality. Minor differences are apparent (silica, zinc, and nutrient concentrations) that may be a result of sampling different springs, plumbing modifications (engineered collection and distribution infrastructure), different analytical techniques, and the natural geochemical differences characteristic of most ground-water systems.

Water-temperature data (continuous and the temperatures collected at the time of water-quality sampling) do not indicate any long-term change in temperature through time. Similar to data presented in previous investigations, the water temperatures varied between springs and also varied at individual springs because of a variety of factors, including seasonal temperature, shallow-flow path recharge contribution, changes in the amount of spring discharge supplied to the spring reservoir, and construction on the network of supply pipes.

The water temperature fluctuations in response to mixing of hot-spring water with locally derived recharge after a storm event varied with the amount of rainfall. For example, at Spring 46 storm events smaller than about 1.5 inches resulted in a temperature decrease of $0.5^{\circ} \mathrm{C}$ or less. However, storm events greater than about 1.5 inches resulted in highly variable decreases in water temperature: a 1.8-inch event caused a $2.7^{\circ} \mathrm{C}$ decrease in water temperature, but a 2.4-inch event caused only a $0.26^{\circ} \mathrm{C}$ decrease in water temperature.

The response time for the water temperature to begin decreasing from the baseline temperature as a result of recharge from a storm event was highly variable. Storm-event, start-time data from automated rain gages indicated that water temperature at Spring 46 and Spring 25 began decreasing from the baseline temperature as quickly as 1 hour after the beginning of a storm. The minimum response time for water temperature at Spring 8 was 4 hours and at Spring 17 was 8 hours.

Water-quality, water-temperature, isotopic, and radiochemical data can help assess the influence of locally derived recharge on water quality of the hot springs by providing information on the degree of mixing between deep flow-path, hot-water recharge and shallow flow-path, cold-water recharge in the discharge area.

Temperatures for shallow-flow-path waters in the area of HSNP typically are about $17^{\circ} \mathrm{C}$ (near mean annual temperature). Temperatures for deep flow-path waters range from $54.2^{\circ} \mathrm{C}$ to $63.7^{\circ} \mathrm{C}$, depending on the spring and whether the temperature was a base-flow or stormflow measurement. An estimate of the contribution of cold-water recharge above base flow during storms, using a binary mixing model, indicated the cold-water contribution during storms ranged from 1 to 35 percent.

Water-quality data show distinguishable differences in chemistry of the springs during base-flow and stormflow conditions, that is, all the springs sampled indicated some measure of influence from local recharge. Silica, total dissolved solids, strontium, sulfate, and barium show statistically significant differences between the median values of base-flow and stormflow samples. While natural variations in these proper- 
ties do not degrade water quality, the differences do provide evidence of variability in the factors controlling water quality of the hot springs and show that water quality is influenced by the locally derived, cold-water component of flow to the springs. This younger, locally derived component of flow possibly is susceptible to surface influences associated with urbanization and changing land use that might introduce contaminants into the hot springs and thereby degrade the quality of the resource.

Water temperature and discharge at the spring reservoir have been measured continually for most of the time period from October 1990 through the present. These data provide information about gross spring response to storms and about the total cold-water component of recharge to the springs associated with storms. These data indicate changes in discharge and temperature in response to storms. Temperature data applied to a simple, binary mixing model indicate a 2 to 25 percent cold-water recharge component input to total hotspring flow.

Silica concentrations for shallow flow-path, cold-water recharge typically are about $8 \mathrm{mg} / \mathrm{L}$ (an average of local cold-water well and spring silica concentration values). Silica concentrations for deep-flow path waters are about $47 \mathrm{mg} / \mathrm{L}$. Silica data applied to a binary mixing model indicate a 21 to 31 percent contribution of cold-water recharge to the hot springs during stormflow conditions.

TDS concentrations for shallow flow-path waters typically are about $20 \mathrm{mg} / \mathrm{L}$. TDS concentrations for deep-flowpath waters are about $207 \mathrm{mg} / \mathrm{L}$ (the maximum hot-spring silica concentration measured). TDS data applied to a binary mixing model indicate 10 to 18 percent contribution of coldwater recharge to the hot springs during stormflow conditions.

Low median values for ${ }^{35} \mathrm{~S}$ (less than $0.1 \mathrm{mBq} / \mathrm{L}$ ) and low median tritium values (less than $5.7 \mathrm{pCi} / \mathrm{L}$ ) were measured for the base-flow samples. These values indicate that recent recharge does not contribute significantly to base flow of the hot springs.

Water-quality, water-temperature, isotopic, and radiochemical data provide multiple lines of evidence supporting the importance of the contribution of shallow flow components to hot springs. Binary mixing models using silica and total dissolved solids indicate that cold-water recharge from stormflow contributes an estimated 10 to 31 percent of the flow of hot springs. Models using water temperature indicate that coldwater recharge from stormflow contributes an estimated 1 to 35 percent of the flow of hot springs. Models using ${ }^{87} \mathrm{Sr} /{ }^{86} \mathrm{Sr}$ ratios indicate that cold-water recharge from stormflow contributes an estimated 8 to 17 percent of the flow of the hot springs. Although these data indicate that shallow recharge from stormflow does contribute to the flow of the hot springs, data from additional stormflow events and also from additional hot springs are needed to refine the contribution of cold-water recharge.

\section{Selected References}

Bedinger, M.S., Pearson, F.J., Jr., Reed, J.E., Sniegocki, R.T., and Stone, C.G., 1979, The waters of Hot Springs National Park, Arkansas-Their nature and origin: U.S. Geological Survey Professional Paper 1044-C, 33 p.

Boutton, T.W., Harrison, A.T., and Smith, B.B., 1980, Distribution of biomass of species differing in photosynthetic pathway along an altitudinal transect: Oecologia 45, p. 287-298.

Branner, J.C., 1892, The mineral waters of Arkansas: Arkansas Geological Survey Annual Report for 1891, v. 1, 144 p.

Clark, I.D., and Fritz, P., 1997, Environmental isotopes in hydrogeology: Boca Raton, CRC Press, 328 p.

Claypool, G.E., Holser, W.T., Kaplan, I.R., Sakai, H., and Zak, I., 1980, The age curves of sulfur and oxygen isotopes in marine sulfate and their mutual interpretation: Chemical Geology, v. 28, p. 199-260.

Deines, P., 1980, The isotopic composition of reduced organic carbon in Fritz, P., and Fontes, J.C., eds., Handbook of Environmental Isotope Geochemistry: Amsterdam, Elsevier, 1, p. 329-406.

Faure, Gunter, 1977, Principles of Isotope Geology: New York, New York, John Wiley and Sons, 464 p.

Faure, Gunter, and Mensing, Teresa, 2005, Isotopes-Principles and applications, 3rd ed: New York, New York: John Wiley and Sons, 897 p.

Fournier, R.O., and Rowe, J.J., 1966, Estimation of underground temperature from the silica content of water from hot springs and wetsteam wells: American Journal of Science, v. 264, p. 685-697.

Glascow, W, Jr., 1860, Hot Springs of Arkansas, with their Travertine Formation: St. Louis, Missouri, L. Gast Bro. and Co.

Gonfiantini, R., 1978, Standards for stable isotope measurements in natural compounds: Nature, v. 271, p. 534-536.

Hamilton, J.B., and Blood, R.S., 1932, Report of construction of hot water collecting and distributing system, Hot Springs National Park, Hot Springs, Arkansas: National Park Service unpublished report. 
Hansen, A.H., and Gryskiewicz, D., 2003, Interactions between Heartland National Parks and surrounding land use change: Development of a conceptual models and indicators for monitoring accessed December 13, 2006 at URL http:// www.forestry.umt.edu/research/cesu/NEWCESU/Assets/ Individual\%20Project\%20Reports/NPS\%20Projects/MSU/ 2001Hansen\%20HTLN\%20final\%20report\%20\%20Aug\% 202003.pdf.

Haywood, J.K., 1902, Report of analysis of the waters of the Hot Springs on the Hot Springs Reservation: U.S. 57th Congress, 1st session, Senate Document 282, 78 p.

Hem, J.D., 1985, Study and interpretation of the chemical characteristics of natural water (3rd ed.): U.S. Geological Survey Water-Supply Paper 2254, 263 p.

Hoefs, Jochen, 1987, Stable isotope geochemistry, 3rd ed., Berlin, Springer-Verlag, 241 p.

Holser, W.T., 1977, Catastrophic chemical events in the history of the ocean: Nature, v. 267, p. 403-408.

Kendall, C., and McDonnell, J.J., eds., 1998, Isotope tracers in catchment hydrology: Amsterdam, Elsevier, 839 p.

Koterba, M.T., Wilde, F.D., and Lapham, W.W., 1995, Ground-water data-collection protocols and procedures for the National Water-Quality Assessment Program: Collection and documentation of water-quality samples and related data: U.S. Geological Survey Open-File Report 95-399, 123 p.

Krothe, N.C., and Libra, R.D., 1983, Sulfur isotopes and hydrochemical variations of spring waters in southern Indiana: Journal of Hydrology, v. 81, p. 267-283.

Kuroda, P.K., 1953, Radioactivity tables of some natural waters: Arkansas University Institute Science and Technology, $58 \mathrm{p}$.

Michel, R.L., Campbell, D.H., Clow, D., and Turk, J.T., 2000, Timescales for migration of atmospherically-derived sulphate through an alpine/subalpine watershed: Water Resources Research, v. 36, p. 27-36.

National Park Service, 1997, Resources Management Plan: Hot Springs National Park: National Park Service, 48 p.

National Park Service, 1998, Baseline water quality data inventory and analysis: Hot Springs National Park: National Park Service, Water Resources Division, Technical Report NPS/NRWRD/NRTR-98/150, 426 p.

Owen, D.D., 1860, Second report of a geological reconnaissance of the middle southern counties of Arkansas: Philadelphia, Pa., C. Sherman and Sons, p. 18-27.
Phillips, Donald, and Koch, Paul, 2002, Incorporating concentration dependence in stable isotope mixing models: Oecologia, v. 130, p. 114-125.

Rantz, S.E., and others, 1982, Measurement and computation of streamflow: Volume 1. Measurement of stage and discharge: U.S. Geological Survey Water Supply Paper 2175, $284 \mathrm{p}$.

U.S. Environmental Protection Agency, 2003, List of contaminants and their MCL's accessed May 21, 2003 at URL http://www.epa.gov/safewater/mcl.html.

Wagner, R.J., Mattraw, H.C., Ritz, G.F., and Smith, B. A., 2000, Guidelines and standard procedures for continuous water-quality monitors: Site selection, field operation, calibration, record computation, and reporting: U.S. Geological Survey Water-Resources Investigations Report 00-4252, 14 p.

Weed, W.H., 1902, Geological sketch of Hot Springs, Arkansas: U.S. 57th Congress, 1st session, Senate Document 282, p. 79-94.

Yeatts, D.S., 2006, Characteristics of thermal springs and the shallow ground-water system at Hot Springs National Park, Arkansas: U.S. Geological Survey Scientific Investigations Report 2006-5001, 35 p. 
Table 3. Nutrients, major ion, trace element, isotope, radiochemical, physical property, field measurement, and bacteria

[Base-flow sample collected September 2000; Stormflow sample collected October 2001; mg/L, milligrams per liter; mg/L, micrograms $\mathrm{mBeq} / \mathrm{L}$, milli-Becquerels per liter; $\mu \mathrm{S} / \mathrm{cm}$ at $25 \mathrm{deg}$. C, microsiemens per centimeter at 25 degrees Celsius; <, less than; E, estimated;

\begin{tabular}{|c|c|c|c|c|c|c|c|c|}
\hline \multirow[b]{3}{*}{ Constituent name } & \multirow{3}{*}{$\begin{array}{l}\text { Maxi- } \\
\text { mum } \\
\text { contam- } \\
\text { inant } \\
\text { level }\end{array}$} & \multirow{3}{*}{$\begin{array}{l}\text { Method } \\
\text { reporting } \\
\text { level }\end{array}$} & \multicolumn{6}{|c|}{ Hot springs } \\
\hline & & & \multicolumn{3}{|c|}{ Base flow } & \multicolumn{3}{|c|}{ Stormflow } \\
\hline & & & Minimum & Median & Maximum & Minimum & Median & Maximum \\
\hline \multicolumn{9}{|l|}{ Nutrients (mg/L) } \\
\hline $\begin{array}{l}\text { Nitrogen ammonia, as } \\
\text { nitrogen, total }\end{array}$ & -- & 0.10 & $<0.10$ & $<0.10$ & $<0.10$ & $<0.10$ & $<0.10$ & $<0.10$ \\
\hline $\begin{array}{l}\text { Nitrogen nitrate, as nitro- } \\
\text { gen, dissolved }\end{array}$ & -- & 0.5 & $<0.5$ & $<0.5$ & $<.0 .5$ & -- & -- & -- \\
\hline $\begin{array}{l}\text { Nitrite plus nitrate, as } \\
\text { nitrogen, total }\end{array}$ & 10 & 0.10 & $<0.10$ & $<0.10$ & 0.10 & $<0.10$ & $<0.10$ & $<0.10$ \\
\hline $\begin{array}{l}\text { Phosphorus ortho, as } \\
\text { phosphorus, dissolved }\end{array}$ & -- & 0.5 & $<0.5$ & $<0.5$ & $<0.5$ & -- & -- & -- \\
\hline Phosphorus, total & -- & 0.05 & $<.05$ & 0.29 & 0.51 & E.028 & E.042 & 0.11 \\
\hline \multicolumn{9}{|l|}{ Major ions (mg/L) } \\
\hline Calcium, total & -- & 0.2 & 38.9 & 42.6 & 47.9 & 38.0 & 41.2 & 41.9 \\
\hline Magnesium, total & -- & 0.20 & 4.22 & 4.70 & 4.97 & 4.20 & 4.30 & 4.37 \\
\hline Potassium, total & -- & 3 & $<3$ & $<3$ & $<3$ & $<3$ & $<3$ & $<3$ \\
\hline Sodium, total recoverable & -- & 5 & $<5$ & $<5$ & $<5$ & $<5$ & $<5$ & $<5$ \\
\hline Chloride, dissolved & -- & 3.0 & $<3.0$ & $<3.0$ & $<3.0$ & $<3.0$ & $<3.0$ & $<3.0$ \\
\hline Fluoride, dissolved & 4 & 1.0 & $<1.0$ & $<1.0$ & $<1.0$ & $<1.0$ & $<1.0$ & $<1.0$ \\
\hline Silica, total & -- & 0.5 & 40.8 & 44.9 & 46.9 & 35.1 & 36.3 & 38.7 \\
\hline Sulfate, dissolved & -- & 5.0 & 7.0 & 7.3 & 7.5 & 6.8 & 7.0 & 7.3 \\
\hline \multicolumn{9}{|l|}{ Trace elements $(\mu \mathrm{g} / \mathrm{L})$} \\
\hline Aluminum, total & -- & 100 & $<100$ & $<100$ & $<100$ & $<100$ & $<100$ & 106 \\
\hline Antimony, total & 6 & 10.0 & $<10.0$ & $<10.0$ & $<10.0$ & $<10.0$ & $<10.0$ & $<10.0$ \\
\hline Arsenic, total & 10 & 10.0 & $<10.0$ & $<10.0$ & $<10.0$ & $<10.0$ & $<10.0$ & $<10.0$ \\
\hline Barium, total & 2,000 & 10.0 & 75.5 & 133 & 141 & 87.7 & 146 & 156 \\
\hline Beryllium, total & 40 & 5.0 & $<5.0$ & $<5.0$ & $<5.0$ & $<5.0$ & $<5.0$ & $<5.0$ \\
\hline Boron, total & -- & 100 & $<100$ & $<100$ & $<100$ & $<100$ & $<100$ & $<100$ \\
\hline Cadmium, total & 5 & 5.0 & $<5.0$ & $<5.0$ & 0.5 & $<5.0$ & $<5.0$ & $<5.0$ \\
\hline Chromium, total & 100 & 10.0 & $<10.0$ & $<10.0$ & $<10.0$ & $<10.0$ & $<10.0$ & $<10.0$ \\
\hline Cobalt, total & -- & 10.0 & $<10.0$ & $<10.0$ & $<10.0$ & $<10.0$ & $<10.0$ & $<10.0$ \\
\hline Copper, total & -- & 10.0 & $<10.0$ & $<10.0$ & $<10.0$ & $<10.0$ & $<10.0$ & $<10.0$ \\
\hline
\end{tabular}


data for samples collected at hot- and cold-water springs in 2000 and 2001.

per liter; pCi/L, picocuries per liter; VSMOW, Vienna standard mean ocean water;

--, data unavailable; n/a, not applicable]

\begin{tabular}{|c|c|c|c|c|c|c|c|}
\hline \multicolumn{2}{|c|}{ Spring 42} & \multicolumn{2}{|c|}{ Spring 46} & \multicolumn{2}{|c|}{ Spring 33} & \multicolumn{2}{|c|}{ Spring 25} \\
\hline Base flow & Stormflow & Base flow & Stormflow & Base flow & Stormflow & Base flow & Stormflow \\
\hline$<0.1$ & E0.056 & E0.053 & E0.042 & $<0.1$ & E0.060 & E0.032 & E0.041 \\
\hline$<0.5$ & -- & E.17 & -- & $<0.5$ & -- & $<0.5$ & -- \\
\hline E0.064 & $<0.10$ & $<0.1$ & E0.053 & E0.036 & E0.090 & E0.054 & $<0.10$ \\
\hline$<0.5$ & -- & $<0.5$ & -- & $<0.5$ & -- & $<0.5$ & -- \\
\hline 0.49 & E0.041 & 0.065 & E0.048 & 0.46 & 0.087 & 0.51 & E0.036 \\
\hline 39.3 & 41.2 & 43.5 & 41.7 & 42.6 & 41.6 & 38.9 & 41.9 \\
\hline 4.29 & 4.32 & 4.69 & 4.34 & 4.72 & 4.36 & 4.22 & 4.37 \\
\hline E1.31 & E1.13 & E1.39 & E1.13 & E1.44 & E1.13 & E1.24 & E1.22 \\
\hline E3.3 & E2.6 & E4.1 & E2.8 & E3.9 & $\mathrm{E} 2.3$ & E2.9 & $\mathrm{E} 2.5$ \\
\hline E2.3 & E2.8 & E2.4 & E2.7 & E2.4 & E2.7 & E2.3 & E2.7 \\
\hline E0.18 & E0.22 & E0.19 & E0.22 & E0.19 & E0.22 & E0.19 & E0.22 \\
\hline 40.8 & 36.3 & 45.6 & 36.8 & 44.9 & 38.3 & 41 & 35.8 \\
\hline 7.1 & 7.3 & 7.3 & 7.1 & 7.5 & 7.2 & 7.4 & 7.0 \\
\hline$<100$ & $<100$ & $<100$ & 106 & $<100$ & E95.0 & $<100$ & $<100$ \\
\hline$<10.0$ & $<10.0$ & $<10.0$ & $<10.0$ & $<10.0$ & $<10.0$ & $<10.0$ & $<10.0$ \\
\hline$<10.0$ & $<10.0$ & $<10.0$ & $<10.0$ & $<10.0$ & $<10.0$ & $<10.0$ & $<10.0$ \\
\hline 136 & 147 & 136 & 142 & 141 & 156 & 129 & 152 \\
\hline$<5.0$ & $<5.0$ & E1.2 & $<5.0$ & E1.4 & $<5.0$ & $<5.0$ & $<5.0$ \\
\hline E11.4 & E19.2 & E10.4 & E19.5 & E9.6 & E17.4 & E14.1 & E16.7 \\
\hline$<5.0$ & $<5.0$ & $<5.0$ & $<5.0$ & $<5.0$ & $<5.0$ & $<5.0$ & $<5.0$ \\
\hline$<10.0$ & $<10.0$ & $<10.0$ & $<10.0$ & $<10.0$ & $<10.0$ & $<10.0$ & $<10.0$ \\
\hline$<10.0$ & $<10.0$ & $<10.0$ & $<10.0$ & $<10.0$ & $<10.0$ & $<10.0$ & $<10.0$ \\
\hline$<10.0$ & $<10.0$ & $<10.0$ & $<10.0$ & $<10.0$ & $<10.0$ & $<10.0$ & $<10.0$ \\
\hline
\end{tabular}


Table 3. Nutrient, major ion, trace element, isotope, radiochemical, physical property, field measurement, and bacteria [Base-flow sample collected September 2000; Stormflow sample collected October 2001; mg/L, milligrams per liter; $\mu \mathrm{g} / \mathrm{L}$, micrograms $\mathrm{mBeq} / \mathrm{L}$, milli-Becquerels per liter; $\mu \mathrm{S} / \mathrm{cm}$ at $25 \mathrm{deg}$. C, microsiemens per centimeter at 25 degrees Celsius; <, less than; E, estimated;

\begin{tabular}{|c|c|c|c|c|c|c|c|c|}
\hline \multirow[b]{3}{*}{ Constituent name } & \multirow[b]{3}{*}{$\begin{array}{c}\text { Maxi- } \\
\text { mum } \\
\text { contam- } \\
\text { inant } \\
\text { level }\end{array}$} & \multirow[b]{3}{*}{$\begin{array}{l}\text { Method } \\
\text { report- } \\
\text { ing } \\
\text { level }\end{array}$} & \multicolumn{6}{|c|}{ Hot springs } \\
\hline & & & \multicolumn{3}{|c|}{ Base flow } & \multicolumn{3}{|c|}{ Stormflow } \\
\hline & & & Minimum & Median & Maximum & Minimum & Median & Maximum \\
\hline Iron, total & -- & 100 & $<100$ & $<100$ & $<100$ & $<100$ & $<100$ & 208 \\
\hline Lead, total & -- & 3.0 & $<3.0$ & $<3.0$ & $<3.0$ & $<3.0$ & $<3.0$ & 3.5 \\
\hline Manganese, total & -- & 10.0 & E1.6 & 215 & 231 & $<10.0$ & 234 & 261 \\
\hline Mercury, total rec. & 2 & 0.2 & $<0.2$ & $<0.2$ & $<0.2$ & $<0.20$ & $<0.20$ & 0.22 \\
\hline Molybdenum, total & -- & 20.0 & $<20.0$ & $<20.0$ & $<20.0$ & $<20.0$ & $<20.0$ & $<20.0$ \\
\hline Nickel, total & -- & 40.0 & $<40.0$ & $<40.0$ & $<40.0$ & $<40.0$ & $<40.0$ & $<40.0$ \\
\hline Selenium, total & & 5.0 & $<5.0$ & $<5.0$ & $<5.0$ & $<5.0$ & $<5.0$ & $<5.0$ \\
\hline Silver, total & 50 & 10.0 & $<10.0$ & $<10.0$ & $<10.0$ & $<10.0$ & $<10.0$ & $<10.0$ \\
\hline Strontium, total & -- & 10.0 & 93.8 & 102 & 110 & 108 & 114 & 117 \\
\hline Thallium, total & 2 & 10.0 & $<10.0$ & $<10.0$ & $<10.0$ & $<10.0$ & $<10.0$ & $<10.0$ \\
\hline Tin, total & -- & 100 & $<100$ & $<100$ & $<100$ & $<100$ & $<100$ & $<100$ \\
\hline Vanadium, total & -- & 10.0 & $<10.0$ & $<10.0$ & $<10.0$ & $<10.0$ & $<10.0$ & $<10.0$ \\
\hline Zinc, total & -- & 20.0 & $<20.0$ & $<20.0$ & 20.4 & $<20.0$ & $<20.0$ & $<20.0$ \\
\hline \multicolumn{9}{|l|}{ Isotopes and radiochemicals } \\
\hline Carbon $\delta^{13} \mathrm{C}$ ratio per million & -- & $\mathrm{n} / \mathrm{a}$ & -14.09 & -13.83 & -13.55 & -14.19 & -13.93 & -13.49 \\
\hline $\begin{array}{l}\text { Carbon-14, counting error, water, filtered, } \\
\text { percent }\end{array}$ & -- & $\mathrm{n} / \mathrm{a}$ & 0.34 & -- & 0.34 & -- & -- & -- \\
\hline Carbon-14, water, filtered, percent & -- & $\mathrm{n} / \mathrm{a}$ & 37.72 & -- & 37.72 & -- & -- & -- \\
\hline Radium 226 dissolved, planchet count (pCi/L) & -- & 0.1 & $<0.1$ & 2.44 & 3.17 & -0.0203 & 2.47 & 2.96 \\
\hline
\end{tabular}


data for samples collected at hot- and cold-water springs in 2000 and 2001.-Continued

per liter; $\mathrm{pCi} / \mathrm{L}$, picocuries per liter; VSMOW, Vienna standard mean ocean water;

-- data unavailable; n/a, not applicable]

Spring 42

Spring 46

Spring 33

Spring 25

\begin{tabular}{|c|c|c|c|c|c|c|c|}
\hline Base flow & Stormflow & Base flow & Stormflow & Base flow & Stormflow & Base flow & Stormflow \\
\hline E36.9 & E19.3 & E24.5 & E44.3 & E60.3 & E36.9 & E20.0 & E39.1 \\
\hline$<3.0$ & $<3.0$ & $<3.0$ & $<3.0$ & $<3.0$ & 3.5 & $<3.0$ & $<3.0$ \\
\hline 231 & 239 & 196 & 198 & 230 & 261 & 215 & 246 \\
\hline$<0.2$ & E0.047 & $<0.2$ & $<0.20$ & $<0.2$ & $<0.20$ & $<0.2$ & $<0.20$ \\
\hline$<20.0$ & $<20.0$ & $<20.0$ & $<20.0$ & $<20.0$ & $<20.0$ & $<20.0$ & $<20.0$ \\
\hline$<40.0$ & $<40.0$ & $<40.0$ & $<40.0$ & $<40.0$ & $<40.0$ & $<40.0$ & $<40.0$ \\
\hline$<5.0$ & $<5.0$ & $<5.0$ & $<5.0$ & $<5.0$ & $<5.0$ & $<5.0$ & $<5.0$ \\
\hline$<10.0$ & $<10.0$ & $<10.0$ & $<10.0$ & $<10.0$ & $<10.0$ & $<10.0$ & $<10.0$ \\
\hline 104 & 114 & 110 & 117 & 110 & 114 & 99.4 & 117 \\
\hline$<10.0$ & $<10.0$ & $<10.0$ & $<10.0$ & $<10.0$ & $<10.0$ & $<10.0$ & $<10.0$ \\
\hline$<100.0$ & $<100$ & $<100.0$ & $<100$ & $<100.0$ & $<100$ & $<100.0$ & $<100$ \\
\hline$<10.0$ & $<10.0$ & $<10.0$ & $<10.0$ & $<10.0$ & $<10.0$ & $<10.0$ & $<10.0$ \\
\hline 20.4 & E4.4 & $<20.0$ & $<20.0$ & E10.0 & E13.3 & $<20.0$ & $<20.0$ \\
\hline-14.0 & -14.16 & -13.65 & -13.83 & -13.89 & -13.88 & -14.08 & -14.19 \\
\hline-- & -- & 0.34 & -- & -- & -- & -- & -- \\
\hline-- & -- & 37.72 & -- & -- & -- & -- & -- \\
\hline 2.44 & 2.47 & 2.26 & 2.04 & 3.05 & 2.64 & 3.17 & 2.96 \\
\hline
\end{tabular}


Table 3. Nutrient, major ion, trace element, isotope, radiochemical, physical property, field measurement, and bacteria [Base-flow sample collected September 2000; Stormflow sample collected October 2001; mg/L, milligrams per liter; $\mu \mathrm{g} / \mathrm{L}$, micrograms $\mathrm{mBeq} / \mathrm{L}$, milli-Becquerels per liter; $\mu \mathrm{S} / \mathrm{cm}$ at $25 \mathrm{deg}$. C, microsiemens per centimeter at 25 degrees Celsius; <, less than; E, estimated;

\begin{tabular}{|c|c|c|c|c|c|c|c|c|}
\hline \multirow[b]{3}{*}{ Constituent name } & \multirow{3}{*}{$\begin{array}{l}\text { Maxi- } \\
\text { mum } \\
\text { contam- } \\
\text { inant } \\
\text { level }\end{array}$} & \multirow{3}{*}{$\begin{array}{l}\text { Method } \\
\text { reporting } \\
\text { level }\end{array}$} & \multicolumn{6}{|c|}{ Hot springs } \\
\hline & & & \multicolumn{3}{|c|}{ Base flow } & \multicolumn{3}{|c|}{ Stormflow } \\
\hline & & & Minimum & Median & Maximum & Minimum & Median & Maximum \\
\hline $\begin{array}{l}\text { Radium 228, dissolved } \\
\qquad(\mathrm{pCi} / \mathrm{L})\end{array}$ & -- & 1.0 & $<1.0$ & $<1.0$ & 1.4 & 0.329 & 0.538 & 1.08 \\
\hline $\begin{array}{l}\text { Radium-226, dissolved } \\
\text { (pCi/L) }\end{array}$ & 5 & $\mathrm{n} / \mathrm{a}$ & 0.0348 & 0.571 & 0.713 & 0.029 & 0.578 & 0.677 \\
\hline $\begin{array}{l}\text { Radium-228, dissolved } \\
\text { (pCi/L) }\end{array}$ & $\begin{array}{l}\text { (combined- } \\
\text { with } \\
\text { Radium- } \\
\text { 228) }\end{array}$ & $\mathrm{n} / \mathrm{a}$ & 0.335 & 0.419 & 0.568 & 0.332 & 0.428 & 0.501 \\
\hline Tritium, total (pCi/L) & -- & 5.7 & $<5.7$ & $<5.7$ & 9.6 & $<5.7$ & 1.6 & 3.5 \\
\hline $\begin{array}{l}\text { Tritium, total, } 2 \text { sigma } \\
\text { PE (pCi/L) }\end{array}$ & -- & $\mathrm{n} / \mathrm{a}$ & 3.8 & 3.8 & 4.5 & 1.9 & 2.6 & 2.6 \\
\hline Tritium units & -- & 1.78 & 1.19 & 1.19 & 1.41 & 0.59 & 0.81 & 0.81 \\
\hline $\begin{array}{l}\text { Uranium-234, } 2 \text { sigma } \\
\text { precision estimate } \\
(\mathrm{pCi} / \mathrm{L})\end{array}$ & -- & & 0.00123 & 0.0171 & 0.0273 & 0.00484 & 0.00908 & 0.0111 \\
\hline $\begin{array}{l}\text { Uranium-234, dissolved. } \\
\quad(\mathrm{pCi} / \mathrm{L})\end{array}$ & -- & 0.1 & $<0.1$ & $<0.1$ & $<0.1$ & 0.00262 & 0.0105 & 0.0184 \\
\hline $\begin{array}{l}\text { Uranium-235, } 2 \text { sigma } \\
\text { precision estimate } \\
(\mathrm{pCi} / \mathrm{L})\end{array}$ & -- & $\mathrm{n} / \mathrm{a}$ & 0.00237 & 0.00873 & 0.0273 & 0.00122 & 0.00367 & 0.00812 \\
\hline $\begin{array}{l}\text { Uranium-235, dissolved } \\
\quad(\mathrm{pCi} / \mathrm{L})\end{array}$ & -- & 0.1 & $<0.1$ & $<0.1$ & $<0.1$ & -0.00061 & 0.000319 & 0.0045 \\
\hline $\begin{array}{l}\text { Uranium-238, } 2 \text { sigma } \\
\text { precision estimate } \\
(\mathrm{pCi} / \mathrm{L})\end{array}$ & -- & $\mathrm{n} / \mathrm{a}$ & 0.00892 & 0.0159 & 0.0273 & 0.00507 & 0.00661 & 0.00825 \\
\hline $\begin{array}{l}\text { Uranium-238, dissolved } \\
\quad(\mathrm{pCi} / \mathrm{L})\end{array}$ & -- & 0.1 & $<0.1$ & $<0.1$ & $<0.1$ & 0.00262 & 0.00472 & 0.00766 \\
\hline Deuterium, VSMOW, \%o & -- & $\mathrm{n} / \mathrm{a}$ & -30.05 & -29.04 & -28.26 & -30.95 & -30.035 & -27.61 \\
\hline Oxygen 18, VSMOW, $\%$ o & -- & $\mathrm{n} / \mathrm{a}$ & -5.56 & -5.5 & -5.16 & -5.57 & -5.51 & -5.46 \\
\hline Strontium 87/86 & -- & $\mathrm{n} / \mathrm{a}$ & 0.71193 & 0.71195 & 0.71197 & 0.71192 & 0.71197 & 0.71200 \\
\hline Sulfur 35 (mBeq/L) & -- & 0.1 & $<0.1$ & $<0.1$ & 7 & -0.4 & 0.1 & 1.8 \\
\hline $\begin{array}{l}\text { Sulfur } \delta^{34} S \text {, parts per } \\
\text { thousand }\end{array}$ & -- & $\mathrm{n} / \mathrm{a}$ & -5.65 & -5.28 & -4.97 & -5.7 & -5.15 & -4.96 \\
\hline
\end{tabular}


data for samples collected at hot- and cold-water springs in 2000 and 2001.-Continued

per liter; $\mathrm{pCi} / \mathrm{L}$, picocuries per liter; VSMOW, Vienna standard mean ocean water;

--, data unavailable; n/a, not applicable]

\begin{tabular}{|c|c|c|c|c|c|c|c|}
\hline \multicolumn{2}{|c|}{ Spring 42} & \multicolumn{2}{|c|}{ Spring 46} & \multicolumn{2}{|c|}{ Spring 33} & \multicolumn{2}{|c|}{ Spring 25} \\
\hline Base flow & Stormflow & Base flow & Stormflow & Base flow & Stormflow & Base flow & Stormflow \\
\hline 1.19 & 0.476 & $<1.0$ & 0.706 & $<1.0$ & 0.538 & $<1.0$ & 0.395 \\
\hline 0.571 & 0.576 & 0.539 & 0.495 & 0.693 & 0.608 & 0.713 & 0.677 \\
\hline 0.497 & 0.437 & 0.449 & 0.467 & 0.419 & 0.428 & 0.414 & 0.397 \\
\hline$<5.7$ & -1 & $<5.7$ & 0.6 & 6.7 & 3.5 & $<5.7$ & 0 \\
\hline 3.8 & 2.6 & 3.8 & 1.9 & 4.5 & 2.6 & 3.8 & 2.6 \\
\hline 1.19 & 0.81 & 1.19 & 0.59 & 1.41 & 0.81 & 1.19 & 0.81 \\
\hline 0.0171 & 0.00484 & 0.0273 & 0.00908 & 0.0203 & 0.00978 & 0.0235 & 0.00825 \\
\hline$<0.1$ & 0.0034 & $<0.1$ & 0.0097 & $<0.1$ & 0.0155 & $<0.1$ & 0.00766 \\
\hline 0.00237 & 0.00341 & 0.0273 & 0.00122 & 0.00655 & 0.00344 & 0.0125 & 0.00367 \\
\hline$<0.1$ & 0.0017 & $<0.1$ & -0.00061 & $<0.1$ & -0.00028 & $<0.1$ & 0.000319 \\
\hline 0.0124 & 0.0069 & 0.0273 & 0.00544 & 0.0177 & 0.00507 & 0.0197 & 0.00825 \\
\hline$<0.1$ & 0.00679 & $<0.1$ & 0.00394 & $<0.1$ & 0.00367 & $<0.1$ & 0.00766 \\
\hline-29.19 & -27.61 & -28.26 & -30.04 & -29.04 & -30.95 & -30.05 & -29.11 \\
\hline-5.49 & -5.51 & -5.41 & -5.48 & -5.16 & -5.48 & -5.5 & -5.54 \\
\hline 0.71193 & 0.71195 & 0.71196 & 0.71197 & 0.71193 & 0.71196 & 0.71194 & 0.71196 \\
\hline$<1$ & 0.9 & $<1$ & -0.1 & $<1$ & 0.8 & $<1$ & 1.8 \\
\hline-5.5 & -5.19 & -- & -5.14 & -- & -5.7 & -4.97 & -4.96 \\
\hline
\end{tabular}


Table 3. Nutrient, major ion, trace element, isotope, radiochemical, physical property, field measurement, and bacteria

[Base-flow sample collected September 2000; Stormflow sample collected October 2001; mg/L, milligrams per liter; $\mu \mathrm{g} / \mathrm{L}$, micrograms $\mathrm{mBeq} / \mathrm{L}$, milli-Becquerels per liter; $\mu \mathrm{S} / \mathrm{cm}$ at $25 \mathrm{deg}$. C, microsiemens per centimeter at 25 degrees Celsius; <, less than; E, estimated;

\begin{tabular}{|c|c|c|c|c|c|c|c|c|}
\hline \multirow[b]{3}{*}{ Constituent name } & \multirow{3}{*}{$\begin{array}{l}\text { Maxi- } \\
\text { mum } \\
\text { contam- } \\
\text { inant } \\
\text { level }\end{array}$} & \multirow[b]{3}{*}{$\begin{array}{l}\text { Method } \\
\text { reporting } \\
\text { level }\end{array}$} & & \multicolumn{5}{|c|}{ Hot springs } \\
\hline & & & \multicolumn{3}{|c|}{ Base flow } & \multicolumn{3}{|c|}{ Stormflow } \\
\hline & & & Minimum & Median & Maximum & Minimum & Median & Maximum \\
\hline \multicolumn{9}{|l|}{$\begin{array}{l}\text { Physical properties, } \\
\text { field parameters, and } \\
\text { bacteria }\end{array}$} \\
\hline $\begin{array}{l}\text { Total dissolved solids } \\
\text { (residue on evaporation } \\
\text { at } 180 \text { degrees Celsius) }\end{array}$ & -- & 0.1 & 177 & 194 & 207 & 174 & 182 & 188 \\
\hline $\mathrm{pH}$, field (standard units) & & & & & & & & \\
\hline $\begin{array}{l}\text { Specific conductance } \\
(\mu \mathrm{S} / \mathrm{cm} \text { at } 25 \text { deg. } \mathrm{C})\end{array}$ & -- & 2.6 & 267 & 287 & 296 & 238 & 293 & 293 \\
\hline $\begin{array}{l}\text { Water temperature } \\
\quad \text { (degrees Celsius) }\end{array}$ & -- & 0 & 54.2 & 62.7 & 63.7 & 54.2 & 63.6 & 63.6 \\
\hline $\begin{array}{l}\text { Alkalinity, dissolved } \\
\quad\left(\mathrm{mg} / \mathrm{L} \text { as } \mathrm{HCO}_{3}\right)\end{array}$ & -- & 2 & 118 & 125 & 128 & 122 & 136 & 136 \\
\hline $\begin{array}{l}\text { Acid neutralizing Capac- } \\
\text { ity, field }(\mathrm{mg} / \mathrm{L} \text { as }\end{array}$ & -- & 2 & 113 & 123 & 130 & 9 & 129 & 129 \\
\hline $\begin{array}{l}\left.\mathrm{CaCO}_{3}\right) \\
\text { Alkalinity, dissolved } \\
\quad\left(\mathrm{mg} / \mathrm{L} \text { as } \mathrm{HCO}_{3}^{-}\right)\end{array}$ & -- & 2 & 144 & 152 & 156 & 149 & 160 & 166 \\
\hline E. coli (colonies/100 mL) & -- & 1 & $<1$ & $<1$ & K120 & $<1$ & $<1$ & 25 \\
\hline $\begin{array}{l}\text { Coliform, fecal } 0.7 \text { (colo- } \\
\text { nies/100 mL) }\end{array}$ & -- & 1 & $<1$ & $<1$ & K200 & $<1$ & $<1$ & $<1$ \\
\hline
\end{tabular}


data for samples collected at hot- and cold-water springs in 2000 and 2001.-Continued

per liter; $\mathrm{pCi} / \mathrm{L}$, picocuries per liter; VSMOW, Vienna standard mean ocean water; --, data unavailable; n/a, not applicable]

Spring 42

Base flow Stormflow
Spring 46

Base flow Stormflow
Spring 33

Base flow
Spring 25

Stormflow
Base flow Stormflow
194

$$
6.8
$$

275

61.9

128

113

156

$<1$

$<1$
182

6.9

273

62.1

133

126

162

$<1$

$<1$
198

7.4

287

55.7

127

123

155

$<1$

$<1$
179

7.1

254

55.8

131

124

160

$<1$

$<1$
194

6.8

291

58.2

58.6

131

128

160

25

$<1$

6.9

115

151

$<1$

$<1$
207

183

6.7

7.4

278

258
63.7

63.6

25

136

14

10

52

166

$<1 \quad<1$

$<1 \quad<1$

$<1 \quad<1$


Table 3. Nutrient, major ion, trace element, isotope, radiochemical, physical property, field measurement, and bacteria [Base-flow sample collected September 2000; Stormflow sample collected October 2001; mg/L, milligrams per liter; $\mu \mathrm{g} / \mathrm{L}$, micrograms $\mathrm{mBeq} / \mathrm{L}$, milli-Becquerels per liter; $\mu \mathrm{S} / \mathrm{cm}$ at $25 \mathrm{deg}$. C, microsiemens per centimeter at 25 degrees Celsius; <, less than; E, estimated;

\begin{tabular}{|c|c|c|c|c|c|c|}
\hline \multirow[b]{2}{*}{ Constituent name } & \multicolumn{2}{|c|}{ Spring 49} & \multicolumn{2}{|c|}{ Spring 9} & \multicolumn{2}{|c|}{ Spring 8} \\
\hline & Base flow & Stormflow & Base flow & Stormflow & Base flow & Stormflow \\
\hline \multicolumn{7}{|l|}{ Nutrients $(\mathrm{mg} / \mathrm{L})$} \\
\hline Nitrogen ammonia, total & 0.029 & $<0.10$ & E0.046 & E0.039 & -- & E0.033 \\
\hline Nitrogen nitrate, dissolved & E. 17 & -- & E0.18 & -- & E0.17 & -- \\
\hline $\begin{array}{l}\text { Nitrite plus nitrate, as nitrogen, } \\
\text { total }\end{array}$ & $<0.1$ & E0.071 & $<0.1$ & $<0.10$ & -- & E0.031 \\
\hline Phosphorus ortho, dissolved & $<0.5$ & -- & $<0.5$ & -- & $<0.5$ & -- \\
\hline Phosphorus, total & E0.022 & E0.042 & $<0.05$ & E0.040 & -- & 0.11 \\
\hline \multicolumn{7}{|l|}{ Major ions (mg/L) } \\
\hline Calcium, total & 41.4 & 39.8 & 43.2 & 41.1 & 47.2 & 41 \\
\hline Magnesium, total & 4.54 & 4.23 & 4.7 & 4.3 & 4.9 & 4.24 \\
\hline Potassium, total & E1.42 & E1.17 & E1.16 & E1.01 & E1.36 & E.913 \\
\hline Sodium, total recoverable & E3.95 & E2.70 & E3.66 & E2.83 & $\mathrm{E} 4.55$ & E2.07 \\
\hline Chloride, dissolved & E2.4 & E2.7 & E2.3 & E2.7 & E2.3 & E2.7 \\
\hline Fluoride, dissolved & E.19 & E. 22 & E.18 & E.22 & E.19 & E.22 \\
\hline Silica, total & 44.0 & 36.2 & 44.9 & 35.2 & 45.6 & 38.2 \\
\hline Sulfate, dissolved & 7.1 & 6.9 & 7.0 & 6.9 & 7.1 & 6.9 \\
\hline \multicolumn{7}{|l|}{ Trace elements $(\mu \mathrm{g} / \mathrm{L})$} \\
\hline Aluminum, total & $<10.0$ & $<100$ & $<100$ & E95.8 & $<100$ & $<100$ \\
\hline Antimony, total & $<10.0$ & $<10.0$ & $<10.0$ & $<10.0$ & $<10.0$ & $<10.0$ \\
\hline
\end{tabular}


data for samples collected at hot- and cold-water springs in 2000 and 2001.-Continued

per liter; pCi/L, picocuries per liter; VSMOW, Vienna standard mean ocean water;

--, data unavailable; n/a, not applicable]

\begin{tabular}{|c|c|c|c|c|c|c|c|c|c|}
\hline \multicolumn{2}{|c|}{ Spring 17} & \multicolumn{2}{|c|}{ Spring 47} & \multicolumn{2}{|c|}{ Happy Hollow } & \multicolumn{2}{|c|}{ ArScenic } & \multicolumn{2}{|c|}{ Precipitation site } \\
\hline Base flow & Stormflow & Base flow & Stormflow & Base flow & Stormflow & Base flow & Stormflow & Base flow & Stormflow \\
\hline$<0.1$ & E0.038 & -- & E0.042 & 0.13 & $<0.10$ & $<0.1$ & -- & -- & -- \\
\hline E0.2 & -- & E0.17 & -- & E0.18 & -- & $<0.5$ & -- & -- & -- \\
\hline 0.1 & E0.050 & -- & E0.043 & $<0.1$ & $<0.10$ & $<0.1$ & -- & -- & -- \\
\hline$<0.5$ & -- & $<0.5$ & -- & $<0.5$ & -- & $<0.5$ & -- & -- & -- \\
\hline 0.29 & 0.072 & -- & E0.028 & 0.087 & 0.065 & E0.027 & -- & -- & -- \\
\hline 40.7 & 38 & 47.9 & 41.6 & E. 172 & 0.469 & 38.6 & -- & -- & -- \\
\hline 4.71 & 4.20 & 4.97 & 4.30 & 0.263 & 0.262 & 1.51 & -- & -- & -- \\
\hline E1.41 & E0.914 & E1.16 & E1.28 & $<0.3$ & $<3.00$ & E0.611 & -- & -- & -- \\
\hline $\mathrm{E} 4.04$ & $<5.00$ & E3.87 & E2.78 & E1.52 & $<5.00$ & E1.48 & -- & -- & -- \\
\hline E2.3 & E2.7 & E2.4 & E2.7 & E2.6 & 3.5 & E2.8 & -- & -- & -- \\
\hline E0.19 & E0.22 & E0.19 & E0.22 & E0.11 & E0.18 & E0.19 & -- & -- & -- \\
\hline 45.8 & 35.1 & 46.9 & 38.7 & 8.92 & 8.17 & 11.7 & -- & -- & -- \\
\hline 7.4 & 7.1 & 7.3 & 6.8 & E1.4 & E1.8 & 5.6 & -- & -- & $<1.2$ \\
\hline$<100$ & E98.5 & $<100$ & 106 & E34.9 & E91.5 & $<100$ & -- & -- & -- \\
\hline$<10.0$ & $<10.0$ & $<10.0$ & $<10.0$ & $<10.0$ & $<10.0$ & $<10.0$ & -- & -- & -- \\
\hline
\end{tabular}


Table 3. Nutrient, major ion, trace element, isotope, radiochemical, physical property, field measurement, and

[Base-flow sample collected September 2000; Stormflow sample collected October 2001; mg/L, milligrams per liter; $\mu \mathrm{g} / \mathrm{L}$, micrograms $\mathrm{mBeq} / \mathrm{L}$, milli-Becquerels per liter; $\mu \mathrm{S} / \mathrm{cm}$ at $25 \mathrm{deg}$. C, microsiemens per centimeter at 25 degrees Celsius; <, less than; E, estimated:

\begin{tabular}{|c|c|c|c|c|c|c|}
\hline \multirow[b]{2}{*}{ Constituent name } & \multicolumn{2}{|c|}{ Spring 49} & \multicolumn{2}{|c|}{ Spring 9} & \multicolumn{2}{|c|}{ Spring 8} \\
\hline & Base flow & Stormflow & Base flow & Stormflow & Base flow & Stormflow \\
\hline Arsenic, total & $<10.0$ & $<10.0$ & $<10.0$ & $<10.0$ & $<10.0$ & $<10.0$ \\
\hline Barium, total & 101 & 94.2 & 75.5 & 136 & 136 & 146 \\
\hline Beryllium, total & E1.6 & $<5.0$ & E1.5 & $<5.0$ & $<5.0$ & $<5.0$ \\
\hline Boron, total & E131 & E17.3 & E11.7 & E17.1 & E11.1 & E15.9 \\
\hline Cadmium, total & $<5.0$ & $<5.0$ & $<5.0$ & $<5.0$ & $<5.0$ & $<5.0$ \\
\hline Chromium, total & $<10.0$ & $<10.0$ & $<10.0$ & $<10.0$ & $<10.0$ & $<10.0$ \\
\hline Cobalt, total & $<10.0$ & $<10.0$ & $<10.0$ & $<10.0$ & $<10.0$ & $<10.0$ \\
\hline Copper, total & $<10.0$ & $<10.0$ & $<10.0$ & $<10.0$ & E4.9 & $<10.0$ \\
\hline Iron, total & $<100$ & 208 & E18.4 & E21.1 & E13.1 & E6.2 \\
\hline Lead, total & $<3.0$ & $<3.0$ & $<3.0$ & $<3.0$ & $<3.0$ & $<3.0$ \\
\hline Manganese, total & 110 & 85.5 & E1.6 & 203 & 229 & 234 \\
\hline Mercury, total rec. & $<0.20$ & 0.22 & $<0.20$ & $<0.20$ & $<0.20$ & $<0.20$ \\
\hline Molybdenum, total & $<20.0$ & $<20.0$ & $<20.0$ & $<20.0$ & $<20.0$ & $<20.0$ \\
\hline Nickel, total & $<40.0$ & $<40.0$ & $<40.0$ & $<40.0$ & $<40.0$ & $<40.0$ \\
\hline Selenium, total & $<5.0$ & $<5.0$ & $<5.0$ & $<5.0$ & $<5.0$ & $<5.0$ \\
\hline Silver, total & $<10.0$ & $<10.0$ & $<10.0$ & $<10.0$ & $<10.0$ & $<10.0$ \\
\hline Strontium, total & 102 & 113 & 109 & 115 & 94.9 & 113 \\
\hline Thallium, total & $<10.0$ & $<10.0$ & $<10.0$ & $<10.0$ & $<10.0$ & $<10.0$ \\
\hline Tin, total & $<100$ & $<100$ & $<100$ & $<100$ & $<100$ & $<100$ \\
\hline
\end{tabular}


bacteria data for samples collected at hot- and cold-water springs in 2000 and 2001.-Continued per liter; pCi/L, picocuries per liter; VSMOW, Vienna standard mean ocean water; --, data unavailable; n/a, not applicable]

\begin{tabular}{|c|c|c|c|c|c|c|c|c|c|}
\hline \multicolumn{2}{|c|}{ Spring 17} & \multicolumn{2}{|c|}{ Spring 47} & \multicolumn{2}{|c|}{ Happy Hollow } & \multicolumn{2}{|c|}{ ArScenic } & \multicolumn{2}{|c|}{ Precipitation site } \\
\hline Base flow & Stormflow & Base flow & Stormflow & Base flow & Stormflow & Base flow & Stormflow & Base flow & Stormflow \\
\hline$<10.0$ & $<10.0$ & $<10.0$ & $<10.0$ & $<10.0$ & $<10.0$ & $<10.0$ & -- & -- & -- \\
\hline 82.5 & 87.7 & 133 & 147 & E7.2 & 18.7 & E8.1 & -- & -- & -- \\
\hline E1.6 & $<5.0$ & $<5.0$ & $<5.0$ & E1.1 & $<5.0$ & $<5.0$ & -- & -- & -- \\
\hline E11.2 & E16.1 & E8.1 & E16.7 & $<100$ & E12.4 & $<100$ & -- & -- & -- \\
\hline$<5.0$ & $<5.0$ & 0.5 & $<5.0$ & $<5.0$ & $<5.0$ & $<5.0$ & -- & -- & -- \\
\hline$<10.0$ & $<10.0$ & $<10.0$ & $<10.0$ & $<10.0$ & $<10.0$ & $<10.0$ & -- & -- & -- \\
\hline$<10.0$ & $<10.0$ & $<10.0$ & $<10.0$ & $<10.0$ & E.42 & $<10.0$ & -- & -- & -- \\
\hline$<10.0$ & $<10.0$ & E6.1 & $<10.0$ & 11.1 & $<10.0$ & 19.8 & -- & -- & -- \\
\hline E17.0 & $<100$ & E15.8 & E6.8 & E72.7 & E56.5 & 119 & -- & -- & -- \\
\hline$<3.0$ & $<3.0$ & $<3.0$ & $<3.0$ & 4.6 & $<3.0$ & $<3.0$ & -- & -- & -- \\
\hline$<10.0$ & $<10.0$ & 227 & 236 & 10.4 & E6.6 & 41.5 & -- & -- & -- \\
\hline$<0.20$ & $<0.20$ & $<0.20$ & $<0.20$ & $<0.20$ & $<.20$ & $<0.2$ & -- & -- & -- \\
\hline$<20.0$ & $<20.0$ & $<20.0$ & $<20.0$ & $<20.0$ & $<20.0$ & $<20.0$ & -- & -- & -- \\
\hline$<40.0$ & $<40.0$ & $<40.0$ & $<40.0$ & $<40.0$ & $<40.0$ & $<40.0$ & -- & -- & -- \\
\hline$<5.0$ & $<5.0$ & $<5.0$ & $<5.0$ & $<5.0$ & $<5.0$ & $<5.0$ & -- & -- & -- \\
\hline$<10.0$ & $<10.0$ & $<10.0$ & $<10.0$ & $<10.0$ & $<10.0$ & $<10.0$ & -- & -- & -- \\
\hline 102 & 108 & 93.8 & 115 & E2.5 & E5.2 & 135 & -- & -- & -- \\
\hline$<10.0$ & $<10.0$ & $<10.0$ & $<10.0$ & $<10.0$ & $<10.0$ & $<10.0$ & -- & -- & -- \\
\hline$<100$ & $<100$ & $<100$ & $<100$ & $<100$ & $<100$ & $<100$ & -- & -- & -- \\
\hline
\end{tabular}


Table 3. Nutrient, major ion, trace element, isotope, radiochemical, physical property, field measurement, and

[Base-flow sample collected September 2000; Stormflow sample collected October 2001; mg/L, milligrams per liter; $\mu \mathrm{g} / \mathrm{L}$, micrograms $\mathrm{mBeq} / \mathrm{L}$, milli-Becquerels per liter; $\mu \mathrm{S} / \mathrm{cm}$ at $25 \mathrm{deg}$. C, microsiemens per centimeter at 25 degrees Celsius; $<$, less than; E, estimated:

\begin{tabular}{|c|c|c|c|c|c|c|}
\hline \multirow[b]{2}{*}{ Constituent name } & \multicolumn{2}{|c|}{ Spring 49} & \multicolumn{2}{|c|}{ Spring 9} & \multicolumn{2}{|c|}{ Spring 8} \\
\hline & Base flow & Stormflow & Base flow & Stormflow & Base flow & Stormflow \\
\hline Vanadium, total & $<10.0$ & $<10.0$ & $<10.0$ & $<10.0$ & $<10.0$ & $<10.0$ \\
\hline Zinc, total & $<20.0$ & $<20.0$ & $<20.0$ & $<20.0$ & $<20.0$ & $<20.0$ \\
\hline \multicolumn{7}{|l|}{ Isotopes and radiochemicals } \\
\hline Carbon $13 / 12$ ratio per million & -14.08 & -14.1 & -13.83 & -13.93 & -13.55 & -13.75 \\
\hline $\begin{array}{l}\text { Carbon-14, counting error, } \\
\text { water, filtered, percent }\end{array}$ & -- & -- & -- & -- & -- & -- \\
\hline $\begin{array}{l}\text { Carbon-14, water, filtered, } \\
\text { percent }\end{array}$ & -- & -- & -- & -- & -- & -- \\
\hline $\begin{array}{l}\text { Radium } 226 \text { dissolved, plan- } \\
\text { chet count }(\mathrm{pCi} / \mathrm{L})\end{array}$ & 1.82 & 0.153 & 0.196 & 2.45 & 2.76 & 2.48 \\
\hline $\begin{array}{l}\text { Radium 228, dissolved } \\
\quad(\mathrm{pCi} / \mathrm{L})\end{array}$ & $<1.0$ & 0.49 & $<1.0$ & 0.885 & 1.31 & 0.953 \\
\hline $\begin{array}{l}\text { Radium-226, dissolved } \\
\text { (pCi/L) }\end{array}$ & 0.445 & 0.0859 & 0.103 & 0.581 & 0.644 & 0.578 \\
\hline $\begin{array}{l}\text { Radium-228, dissolved } \\
\text { (pCi/L) }\end{array}$ & 0.403 & 0.332 & 0.393 & 0.501 & 0.519 & 0.411 \\
\hline Tritium, total (pCi/L) & 9.6 & 1.9 & $<5.7$ & 1.9 & $<5.7$ & 1.6 \\
\hline $\begin{array}{l}\text { Tritium, total, } 2 \text { sigma PE } \\
(\mathrm{pCi} / \mathrm{L})\end{array}$ & 3.8 & 2.6 & 3.8 & 2.6 & 3.8 & 2.6 \\
\hline Tritium units & 1.19 & 0.81 & 1.19 & 0.81 & 1.19 & 0.81 \\
\hline $\begin{array}{l}\text { Uranium-234 } 2 \text { sigma } \mathrm{PE} \\
(\mathrm{pCi} / \mathrm{L})\end{array}$ & 0.0159 & 0.00819 & 0.0182 & 0.0089 & 0.00123 & 0.00983 \\
\hline Uranium-234,DIS. (pCi/L) & $<0.1$ & 0.0105 & $<0.1$ & 0.0129 & $<0.1$ & 0.0135 \\
\hline $\begin{array}{l}\text { Uranium-235, } 2 \text { sigma PE } \\
(\mathrm{pCi} / \mathrm{L})\end{array}$ & 0.0134 & 0.0046 & 0.00892 & 0.00451 & 0.00615 & 0.00385 \\
\hline
\end{tabular}


bacteria data for samples collected at hot- and cold-water springs in 2000 and 2001.-Continued per liter; pCi/L, picocuries per liter; VSMOW, Vienna standard mean ocean water; --, data unavailable; n/a, not applicable]

\begin{tabular}{|c|c|c|c|c|c|c|c|c|c|}
\hline \multicolumn{2}{|c|}{ Spring 17} & \multicolumn{2}{|c|}{ Spring 47} & \multicolumn{2}{|c|}{ Happy Hollow } & \multicolumn{2}{|c|}{ ArScenic } & \multicolumn{2}{|c|}{ Precipitation site } \\
\hline Base flow & Stormflow & Base flow & Stormflow & Base flow & Stormflow & Base flow & Stormflow & Base flow & Stormflow \\
\hline$<10.0$ & $<10.0$ & $<10.0$ & $<10.0$ & $<10.0$ & $<10.0$ & $<10.0$ & -- & -- & -- \\
\hline$<20.0$ & $<20.0$ & $<20.0$ & $<20.0$ & $\mathrm{E} 4.7$ & $<20.0$ & E11.0 & -- & -- & -- \\
\hline-13.76 & -13.97 & -13.58 & -13.49 & -22.72 & -22.93 & -14.22 & -- & -- & -- \\
\hline-- & -- & -- & -- & -- & -- & 0.43 & -- & -- & -- \\
\hline-- & -- & -- & -- & -- & -- & 47.83 & -- & -- & -- \\
\hline$<0.10$ & -0.0203 & 3.02 & 2.64 & 0.718 & 0.859 & 0.816 & -- & -- & -- \\
\hline$<1.0$ & 0.329 & 1.4 & 1.08 & $<1.0$ & 0.508 & $<1.0$ & -- & -- & -- \\
\hline 0.0348 & 0.029 & 0.684 & 0.613 & 0.223 & 0.254 & 0.246 & -- & -- & -- \\
\hline 0.335 & 0.377 & 0.568 & 0.464 & 0.461 & 0.424 & 0.435 & -- & -- & -- \\
\hline$<5.7$ & 0.6 & $<5.7$ & 1.9 & $<5.7$ & 6.1 & 7.7 & -- & -- & -- \\
\hline 3.8 & 2.6 & 3.8 & 2.6 & 3.8 & 2.6 & 3.8 & -- & -- & -- \\
\hline 1.19 & 0.81 & 1.19 & 0.81 & 1.19 & 0.81 & 1.19 & -- & -- & -- \\
\hline 0.0145 & 0.00953 & 0.0142 & 0.0111 & 0.0377 & 0.0328 & 0.146 & -- & -- & -- \\
\hline$<0.10$ & 0.00262 & $<0.10$ & 0.0184 & $<0.10$ & 0.106 & 0.612 & -- & -- & -- \\
\hline 0.00873 & 0.00812 & 0.00799 & 0.00321 & 0.00861 & 0.00889 & 0.0132 & -- & -- & -- \\
\hline
\end{tabular}


Table 3. Nutrient, major ion, trace element, isotope, radiochemical, physical property, field measurement, and

[Base-flow sample collected September 2000; Stormflow sample collected October 2001; mg/L, milligrams per liter; $\mu \mathrm{g} / \mathrm{L}$, micrograms $\mathrm{mBeq} / \mathrm{L}$, milli-Becquerels per liter; $\mu \mathrm{S} / \mathrm{cm}$ at $25 \mathrm{deg}$. C, microsiemens per centimeter at 25 degrees Celsius; $<$, less than; E, estimated:

\begin{tabular}{|c|c|c|c|c|c|c|}
\hline \multirow[b]{2}{*}{ Constituent name } & \multicolumn{2}{|c|}{ Spring 49} & \multicolumn{2}{|c|}{ Spring 9} & \multicolumn{2}{|c|}{ Spring 8} \\
\hline & Base flow & Stormflow & Base flow & Stormflow & Base flow & Stormflow \\
\hline $\begin{array}{l}\text { Uranium-235, dissolved } \\
(\mathrm{pCi} / \mathrm{L})\end{array}$ & $<0.1$ & 0.00181 & $<0.1$ & 0.00114 & $<0.1$ & 0.0 \\
\hline $\begin{array}{l}\text { Uranium-238 } 2 \text { sigma PE } \\
(\mathrm{pCi} / \mathrm{L})\end{array}$ & 0.0159 & 0.00695 & 0.00892 & 0.00661 & 0.0107 & 0.00552 \\
\hline $\begin{array}{l}\text { Uranium-238, dissolved } \\
\text { (pCi/L) }\end{array}$ & $<0.1$ & 0.00692 & $<0.1$ & 0.00658 & $<0.1$ & 0.00472 \\
\hline Deuterium, VSMOW, \%o & -28.38 & -29.23 & -28.63 & -30.03 & -28.82 & -30.23 \\
\hline Oxygen 18, VSMOW, \%o & -5.56 & -5.47 & -5.52 & -5.56 & -5.56 & -5.57 \\
\hline Strontium 87/86 & 0.71197 & 0.71198 & 0.71195 & 0.71200 & 0.71196 & 0.71198 \\
\hline Sulfur 35 (mBeq/L) & $<1$ & 0.1 & $<1$ & -0.4 & $<1$ & -0.1 \\
\hline Sulfur 34/32 (\%o) & -5.42 & -5.03 & -5.11 & -5.15 & -5.28 & -5.16 \\
\hline \multicolumn{7}{|l|}{$\begin{array}{l}\text { Physical properties, field } \\
\text { parameters, and bacteria }\end{array}$} \\
\hline Total dissolved solids & 194 & 186 & 192 & 182 & 184 & 181 \\
\hline pH, field (standard units) & 7.5 & 6.9 & 7.6 & 7.1 & 7.8 & 7.6 \\
\hline $\begin{array}{l}\text { Specific conductance } \\
\text { (uS/cm at } 25 \text { deg. C) }\end{array}$ & 285 & 263 & 296 & 293 & 290 & 252 \\
\hline $\begin{array}{l}\text { Water temperature (degrees } \\
\text { Celsius }\end{array}$ & 63.5 & 60.4 & 63.7 & 62.8 & 63 & 61.9 \\
\hline $\begin{array}{l}\text { Alkalinity, dissolved } \\
(\mathrm{mg} / \mathrm{L})\end{array}$ & 124 & 131 & 126 & 131 & 125 & 128 \\
\hline $\begin{array}{l}\text { Acid neutralizing capacity, } \\
\text { field }\left(\mathrm{mg} / \mathrm{L} \text { as } \mathrm{CaCO}_{3}\right)\end{array}$ & 125 & 121 & 127 & 129 & 129 & 10 \\
\hline $\begin{array}{l}\text { Alkalinity, dissolved (mg/L } \\
\text { as } \mathrm{HCO}_{3} \text { ) }\end{array}$ & 151 & 160 & 154 & 160 & 152 & 156 \\
\hline $\begin{array}{l}\text { E. coli, mtec mf,w (col./100 } \\
\text { mL) }\end{array}$ & $<1$ & $<1$ & $<1$ & $<1$ & K120 & $<1$ \\
\hline $\begin{array}{l}\text { Coliform fecal } 0.7 \text { (col./100 } \\
\text { mL) }\end{array}$ & $<1$ & $<1$ & $<1$ & $<1$ & K200 & $<1$ \\
\hline
\end{tabular}


bacteria data for samples collected at hot- and cold-water springs in 2000 and 2001._Continued

per liter; pCi/L, picocuries per liter; VSMOW, Vienna standard mean ocean water;

--, data unavailable; $\mathrm{n} / \mathrm{a}$, not applicable]

\begin{tabular}{|c|c|c|c|c|c|c|c|c|c|}
\hline \multicolumn{2}{|c|}{ Spring 17} & \multicolumn{2}{|c|}{ Spring 47} & \multicolumn{2}{|c|}{ Happy Hollow } & \multicolumn{2}{|c|}{ ArScenic } & \multicolumn{2}{|c|}{ Precipitation site } \\
\hline Base flow & Stormflow & Base flow & Stormflow & Base flow & Stormflow & Base flow & Stormflow & Base flow & Stormflow \\
\hline$<0.100$ & 0.0045 & $<0.10$ & 0.000279 & $<0.10$ & 0.0107 & $<0.10$ & -- & -- & -- \\
\hline 0.0247 & 0.00717 & 0.014 & 0.00595 & 0.0153 & 0.0143 & 0.0189 & -- & -- & -- \\
\hline$<0.10$ & 0.00262 & $<0.10$ & 0.00391 & $<0.10$ & 0.0263 & $<0.10$ & -- & -- & -- \\
\hline-29.25 & -30.12 & -29.5 & -29.01 & -31.85 & -32.71 & -28.11 & -- & -- & -66.04 \\
\hline-5.46 & -5.46 & -5.51 & -5.56 & -5.77 & -5.65 & -5.46 & -- & -- & -9.66 \\
\hline 0.71193 & 0.71192 & 0.71196 & 0.71197 & 0.71292 & 0.71202 & 0.70860 & -- & -- & -- \\
\hline$<1$ & 0.1 & 7 & 0.2 & 2.1 & 0.3 & $<1$ & -- & -- & -- \\
\hline-5.65 & -5.23 & -5.14 & -5.1 & -- & 0.46 & 6.25 & -- & -- & 1.2 \\
\hline 177 & 174 & 185 & 176 & 22 & 20 & 119 & -- & -- & -- \\
\hline 6.5 & 7.4 & 7.6 & 7.3 & 4.7 & 5.1 & 6.9 & -- & -- & -- \\
\hline 267 & 238 & 296 & 256 & 22 & 23 & 250 & -- & -- & -- \\
\hline 54.2 & 54.2 & 62.7 & 62.8 & 18 & 17.6 & 19.4 & -- & -- & -- \\
\hline 118 & 122 & 125 & 132 & E1.3 & E1.2 & 92.1 & -- & -- & -- \\
\hline 115 & 9 & 130 & 10 & 3 & 0.4 & 93 & -- & -- & -- \\
\hline 144 & 149 & 152 & 161 & E1.6 & E1.5 & 112 & -- & -- & -- \\
\hline$<1$ & $<1$ & $<1$ & $<1$ & $<1$ & $<1$ & K12 & -- & -- & -- \\
\hline$<1$ & $<1$ & $<1$ & $<1$ & $<1$ & $<1$ & K74 & -- & -- & -- \\
\hline
\end{tabular}


Table 4. Pesticide and semivolatile concentrations for samples collected at hot- and cold-water springs in 2000 and 2001.

[Base-flow sample collected September 2000; Stormflow sample collected October 2001; All concentrations for samples collected are in micrograms per liter; $<$, less than; --, data unavailable]

\begin{tabular}{|c|c|c|c|c|c|c|c|c|c|}
\hline \multirow[b]{2}{*}{ Constituent name } & \multirow[b]{2}{*}{$\begin{array}{c}\text { Maximum } \\
\text { contaminant } \\
\text { level }^{1}\end{array}$} & \multicolumn{2}{|c|}{ Spring 49} & \multicolumn{2}{|c|}{ Spring 9} & \multicolumn{2}{|c|}{ Happy Hollow } & \multicolumn{2}{|c|}{ ArScenic } \\
\hline & & $\begin{array}{l}\text { Base } \\
\text { flow }\end{array}$ & $\begin{array}{l}\text { Storm- } \\
\text { flow }\end{array}$ & $\begin{array}{l}\text { Base } \\
\text { flow }\end{array}$ & $\begin{array}{l}\text { Storm- } \\
\text { flow }\end{array}$ & $\begin{array}{l}\text { Base } \\
\text { flow }\end{array}$ & $\begin{array}{l}\text { Storm- } \\
\text { flow }\end{array}$ & $\begin{array}{l}\text { Base } \\
\text { flow }\end{array}$ & $\begin{array}{l}\text { Storm- } \\
\text { flow }\end{array}$ \\
\hline 1,2,5,6-dibenzanthracene total & -- & $<10$ & $<10$ & $<10$ & $<10$ & -- & $<10$ & $<10$ & -- \\
\hline $\begin{array}{l}\text { 2,4,5-trichlorophenol, whole } \\
\text { water, total }\end{array}$ & -- & $<10$ & $<10$ & $<10$ & $<10$ & -- & $<10$ & $<10$ & -- \\
\hline 2,4,6-trichlorophenol, total & -- & $<10$ & $<10$ & $<10$ & $<10$ & -- & $<10$ & $<10$ & -- \\
\hline 2,4,dimethylphenol, total & -- & $<10$ & $<10$ & $<10$ & $<10$ & -- & $<10$ & $<10$ & -- \\
\hline 2,4-dichlorophenol, total & -- & $<10$ & $<10$ & $<10$ & $<10$ & -- & $<10$ & $<10$ & -- \\
\hline 2,4-dinitrophenol, total & -- & $<50$ & $<50$ & $<50$ & $<50$ & -- & $<50$ & $<50$ & -- \\
\hline 2,4-dinitrotoluene, total & -- & $<10$ & $<10$ & $<10$ & $<10$ & -- & $<10$ & $<10$ & -- \\
\hline 2,6-dinitrotoluene, total & -- & $<10$ & $<10$ & $<10$ & $<10$ & -- & $<10$ & $<10$ & -- \\
\hline 2-chloronaphthalene, total & -- & $<10$ & $<10$ & $<10$ & $<10$ & -- & $<10$ & $<10$ & -- \\
\hline 2-chlorophenol, total & -- & $<10$ & $<10$ & $<10$ & $<10$ & -- & $<10$ & $<10$ & -- \\
\hline $\begin{array}{l}\text { 2-nitroaniline, whole water, } \\
\text { recoverable }\end{array}$ & -- & $<50$ & $<50$ & $<50$ & $<50$ & -- & $<50$ & $<50$ & -- \\
\hline 2-nitrophenol, total & -- & $<10$ & $<10$ & $<10$ & $<10$ & -- & $<10$ & $<10$ & -- \\
\hline 3,3'-dichlorobenzidine, total & -- & $<50$ & $<50$ & $<50$ & $<50$ & -- & $<50$ & $<50$ & -- \\
\hline $\begin{array}{l}\text { 3-nitroaniline, water, whole, } \\
\text { total }\end{array}$ & -- & $<50$ & $<50$ & $<50$ & $<50$ & -- & $<50$ & $<50$ & -- \\
\hline 4,6-dinitroorthocresol, total & -- & $<50$ & $<50$ & $<50$ & $<50$ & -- & $<50$ & $<50$ & -- \\
\hline $\begin{array}{l}\text { 4-bromophenyl phenyl ether, } \\
\text { water, unfiltered, recover- } \\
\text { able }\end{array}$ & -- & $<10$ & $<10$ & $<10$ & $<10$ & -- & $<10$ & $<10$ & -- \\
\hline $\begin{array}{l}\text { 4-chloroaniline, water, filtered, } \\
\text { recoverable }\end{array}$ & -- & $<10$ & $<10$ & $<10$ & $<10$ & -- & $<10$ & $<10$ & -- \\
\hline $\begin{array}{l}\text { 4-chlorophenyl phenyl ether, } \\
\text { water, unfiltered, recover- } \\
\text { able }\end{array}$ & -- & $<10$ & $<10$ & $<10$ & $<10$ & -- & $<10$ & $<10$ & -- \\
\hline $\begin{array}{l}\text { 4-nitroaniline, water, whole, } \\
\text { recoverable }\end{array}$ & -- & $<50$ & $<50$ & $<50$ & $<50$ & -- & $<50$ & $<50$ & -- \\
\hline 4-nitrophenol, total & -- & $<50$ & $<50$ & $<50$ & $<50$ & -- & $<50$ & $<50$ & -- \\
\hline Acenaphthene, total & -- & $<10$ & $<10$ & $<10$ & $<10$ & -- & $<10$ & $<10$ & -- \\
\hline Acenaphthylene, total & -- & $<10$ & $<10$ & $<10$ & $<10$ & -- & $<10$ & $<10$ & -- \\
\hline Aldrin, total (water) & -- & $<0.05$ & $<0.050$ & $<0.05$ & $<0.050$ & -- & $<0.050$ & $<0.05$ & -- \\
\hline Alpha BHC, total & -- & $<0.05$ & $<0.050$ & $<0.05$ & $<0.050$ & -- & $<0.050$ & $<0.005$ & -- \\
\hline Anthracene, total & -- & $<10$ & $<10$ & $<10$ & $<10$ & -- & $<10$ & $<10$ & -- \\
\hline
\end{tabular}


Table 4. Pesticide and semivolatile concentrations for samples collected at hot- and cold-water springs in 2000 and 2001.—Continued

[Base-flow sample collected September 2000; Stormflow sample collected October 2001; All concentrations for samples collected are in micrograms per liter; $<$, less than; --, data unavailable]

\begin{tabular}{|c|c|c|c|c|c|c|c|c|c|}
\hline \multirow[b]{2}{*}{ Constituent name } & \multirow[b]{2}{*}{$\begin{array}{l}\text { Maximum } \\
\text { contaminant } \\
\text { level }^{1}\end{array}$} & \multicolumn{2}{|c|}{ Spring 49} & \multicolumn{2}{|c|}{ Spring 9} & \multicolumn{2}{|c|}{ Happy Hollow } & \multicolumn{2}{|c|}{ ArScenic } \\
\hline & & $\begin{array}{l}\text { Base } \\
\text { flow }\end{array}$ & $\begin{array}{l}\text { Storm- } \\
\text { flow }\end{array}$ & $\begin{array}{l}\text { Base } \\
\text { flow }\end{array}$ & $\begin{array}{l}\text { Storm- } \\
\text { flow }\end{array}$ & $\begin{array}{l}\text { Base } \\
\text { flow }\end{array}$ & $\begin{array}{l}\text { Storm- } \\
\text { flow }\end{array}$ & $\begin{array}{l}\text { Base } \\
\text { flow }\end{array}$ & $\begin{array}{l}\text { Storm- } \\
\text { flow }\end{array}$ \\
\hline $\begin{array}{l}\text { Benzene, nitro-, water, unfil- } \\
\text { tered, recoverable }\end{array}$ & -- & $<10$ & $<10$ & $<10$ & $<10$ & -- & $<10$ & $<10$ & -- \\
\hline Benzo (a) pyrene, total & -- & $<10$ & $<10$ & $<10$ & $<10$ & -- & $<10$ & $<10$ & -- \\
\hline Benzo (b) fluoranthene, total & -- & $<10$ & $<10$ & $<10$ & $<10$ & -- & $<10$ & $<10$ & -- \\
\hline Benzo (k) fluoranthene, total & -- & $<10$ & $<10$ & $<10$ & $<10$ & -- & $<10$ & $<10$ & -- \\
\hline $\begin{array}{l}\text { Benzo(a)anthracene, water, } \\
\text { unfiltered,recoverable }\end{array}$ & -- & $<10$ & $<10$ & $<10$ & $<10$ & -- & $<10$ & $<10$ & -- \\
\hline $\begin{array}{l}\text { Benzo[ghi]perylene, water, } \\
\text { unfiltered, recoverable }\end{array}$ & -- & $<10$ & $<10$ & $<10$ & $<10$ & -- & $<10$ & $<10$ & -- \\
\hline $\begin{array}{l}\text { Beta benzene hexachloride, } \\
\text { total }\end{array}$ & -- & $<0.05$ & $<0.050$ & $<0.05$ & $<0.050$ & -- & $<0.050$ & $<0.05$ & -- \\
\hline $\begin{array}{l}\text { Bis(2-chloroethoxy) methane, } \\
\text { total }\end{array}$ & -- & $<10$ & $<10$ & $<10$ & $<10$ & -- & $<10$ & $<10$ & -- \\
\hline $\begin{array}{l}\text { Bis(2-chloroethyl) ether, wa- } \\
\text { ter, unfiltered, recoverable }\end{array}$ & -- & $<10$ & $<10$ & $<10$ & $<10$ & -- & $<10$ & $<10$ & -- \\
\hline $\begin{array}{l}\text { Bis(2-chloroisopropyl) ether, } \\
\text { total }\end{array}$ & -- & $<10$ & $<10$ & $<10$ & $<10$ & -- & $<10$ & $<10$ & -- \\
\hline $\begin{array}{l}\text { Bis(2-ethylhexyl)phthalate, } \\
\text { whole, water }\end{array}$ & -- & $<10$ & $<10$ & $<10$ & $<10$ & -- & $<10$ & $<10$ & -- \\
\hline $\begin{array}{l}\text { Carbazole, water, unfiltered, } \\
\text { recoverable }\end{array}$ & -- & $<10$ & $<10$ & $<10$ & $<10$ & -- & $<10$ & $<10$ & -- \\
\hline $\begin{array}{l}\text { Chlordane, cis isomer, } \\
\text { water, whole, total }\end{array}$ & -- & $<0.05$ & $<0.050$ & $<0.05$ & $<0.050$ & -- & $<0.050$ & $<0.05$ & -- \\
\hline $\begin{array}{l}\text { Chlordane, trans isomer, } \\
\text { water, whole, total }\end{array}$ & -- & $<0.05$ & $<0.050$ & $<0.05$ & $<0.050$ & -- & $<0.050$ & $<0.05$ & -- \\
\hline Chrysene, total & -- & $<10$ & $<10$ & $<10$ & $<10$ & -- & $<10$ & $<10$ & -- \\
\hline $\begin{array}{l}\text { Cyclopentadiene, hexachloro-, } \\
\text { water, unfiltered, recover- } \\
\text { able }\end{array}$ & -- & $<50$ & $<50$ & $<50$ & $<50$ & -- & $<50$ & $<50$ & -- \\
\hline $\begin{array}{l}\text { Delta benzene hexachloride, } \\
\text { total }\end{array}$ & -- & $<0.05$ & $<0.050$ & $<0.05$ & $<0.050$ & -- & $<0.050$ & $<0.05$ & -- \\
\hline $\begin{array}{l}\text { Dibenzofuran, water, whole, } \\
\text { total }\end{array}$ & -- & $<10$ & $<10$ & $<10$ & $<10$ & -- & $<10$ & $<10$ & -- \\
\hline Dieldrin, total & -- & $<0.05$ & $<0.050$ & $<0.05$ & $<0.050$ & -- & $<0.050$ & $<0.05$ & -- \\
\hline Diethyl phtlate, total & -- & $<10$ & $<10$ & $<10$ & $<10$ & -- & $<10$ & $<10$ & -- \\
\hline Dimethyl phthalate, total & -- & $<10$ & $<10$ & $<10$ & $<10$ & -- & $<10$ & $<10$ & -- \\
\hline Di-n-butylphthalate, total & -- & $<10$ & $<10$ & $<10$ & $<10$ & -- & $<10$ & $<10$ & -- \\
\hline Dinoctyl phthalate, total & -- & $<10$ & $<10$ & $<10$ & $<10$ & -- & $<10$ & $<10$ & -- \\
\hline $\begin{array}{l}\text { Endosulfan I, water, whole, } \\
\text { recoverable }\end{array}$ & -- & $<0.05$ & $<0.050$ & $<0.05$ & $<0.050$ & -- & $<0.050$ & $<0.05$ & -- \\
\hline
\end{tabular}


Table 4. Pesticide and semivolatile concentrations for samples collected at hot- and cold-water springs in 2000 and 2001.—Continued

[Base-flow sample collected September 2000; Stormflow sample collected October 2001; All concentrations for samples collected are in micrograms per liter; $<$, less than; --, data unavailable]

\begin{tabular}{|c|c|c|c|c|c|c|c|c|c|}
\hline \multirow[b]{2}{*}{ Constituent name } & \multirow[b]{2}{*}{$\begin{array}{c}\text { Maximum } \\
\text { contaminant } \\
\text { level }^{1}\end{array}$} & \multicolumn{2}{|c|}{ Spring 49} & \multicolumn{2}{|c|}{ Spring 9} & \multicolumn{2}{|c|}{ Happy Hollow } & \multicolumn{2}{|c|}{ ArScenic } \\
\hline & & $\begin{array}{l}\text { Base } \\
\text { flow }\end{array}$ & $\begin{array}{l}\text { Storm- } \\
\text { flow }\end{array}$ & $\begin{array}{l}\text { Base } \\
\text { flow }\end{array}$ & $\begin{array}{l}\text { Storm- } \\
\text { flow }\end{array}$ & $\begin{array}{l}\text { Base } \\
\text { flow }\end{array}$ & $\begin{array}{l}\text { Storm- } \\
\text { flow }\end{array}$ & $\begin{array}{l}\text { Base } \\
\text { flow }\end{array}$ & $\begin{array}{l}\text { Storm- } \\
\text { flow }\end{array}$ \\
\hline $\begin{array}{l}\text { Endosulfan II, water, unfil- } \\
\text { tered, recoverable }\end{array}$ & -- & $<0.05$ & $<0.050$ & $<0.05$ & $<0.050$ & -- & $<0.050$ & $<0.05$ & -- \\
\hline Endosulfan sulfate, total & -- & $<0.05$ & $<0.050$ & $<0.05$ & $<0.050$ & -- & $<0.050$ & $<0.05$ & -- \\
\hline Endrin aldehyde, total & -- & $<0.05$ & $<0.050$ & $<0.05$ & $<0.050$ & -- & $<0.050$ & $<0.05$ & -- \\
\hline $\begin{array}{l}\text { Endrin, ketone, water, } \\
\text { whole, total }\end{array}$ & -- & $<0.05$ & $<0.050$ & $<0.05$ & $<0.050$ & -- & $<0.050$ & $<0.05$ & -- \\
\hline $\begin{array}{l}\text { Endrin, water, unfiltered, } \\
\text { recoverable }\end{array}$ & 2 & $<0.05$ & $<0.050$ & $<0.05$ & $<0.050$ & -- & $<0.050$ & $<0.05$ & -- \\
\hline Fluoranthene, total & -- & $<10$ & $<10$ & $<10$ & $<10$ & -- & $<10$ & $<10$ & -- \\
\hline Fluorene, total & -- & $<10$ & $<10$ & $<10$ & $<10$ & -- & $<10$ & $<10$ & -- \\
\hline Heptachlor epoxide, total & 0.2 & $<0.05$ & $<0.050$ & $<0.05$ & $<0.050$ & -- & $<0.050$ & $<0.05$ & -- \\
\hline Heptachlor, total & 0.4 & $<0.05$ & $<0.050$ & $<0.05$ & $<0.050$ & -- & $<0.050$ & $<0.05$ & -- \\
\hline Hexachlorobenzene, total & 1 & $<10$ & $<10$ & $<10$ & $<10$ & -- & $<10$ & $<10$ & -- \\
\hline $\begin{array}{l}\text { Indeno }(1,2,3-\mathrm{cd}) \text { pyrene, } \\
\text { total }\end{array}$ & -- & $<10$ & $<10$ & $<10$ & $<10$ & -- & $<10$ & $<10$ & -- \\
\hline Isophorone, total & -- & $<10$ & $<10$ & $<10$ & $<10$ & -- & $<10$ & $<10$ & -- \\
\hline Lindane, total & 0.2 & $<0.05$ & $<0.050$ & $<0.05$ & $<0.050$ & -- & $<0.050$ & $<0.05$ & -- \\
\hline Methoxychlor, total & 4.0 & $<0.10$ & $<0.10$ & $<0.10$ & $<0.10$ & -- & $<0.10$ & $<0.10$ & -- \\
\hline $\begin{array}{l}\text { N-butylbenzyl phthalate, } \\
\text { total }\end{array}$ & -- & $<10$ & $<10$ & $<10$ & $<10$ & -- & $<10$ & $<10$ & -- \\
\hline $\begin{array}{l}\text { N-nitrosodi-n-propylamine, } \\
\text { total }\end{array}$ & -- & $<10$ & $<10$ & $<10$ & $<10$ & -- & $<10$ & $<10$ & -- \\
\hline $\begin{array}{l}\text { N-nitrosodiphenylamine, } \\
\text { total }\end{array}$ & -- & $<10$ & $<10$ & $<10$ & $<10$ & -- & $<10$ & $<10$ & -- \\
\hline P,P' DDD, total & -- & $<0.05$ & $<0.050$ & $<0.05$ & $<0.050$ & -- & $<0.050$ & $<0.05$ & -- \\
\hline P,P' DDE total & -- & $<0.05$ & $<0.050$ & $<0.05$ & $<0.050$ & -- & $<0.050$ & $<0.05$ & -- \\
\hline P,P' DDT, total & -- & $<0.05$ & $<0.050$ & $<0.05$ & $<0.050$ & -- & $<0.050$ & $<0.05$ & -- \\
\hline Parachlorometa cresol, total & -- & $<10$ & $<10$ & $<10$ & $<10$ & -- & $<10$ & $<10$ & -- \\
\hline Pentachlorophenol, total & 1 & $<50$ & $<50$ & $<50$ & $<50$ & -- & $<50$ & $<50$ & -- \\
\hline Phenanthrene, total & -- & $<10$ & $<10$ & $<10$ & $<10$ & -- & $<10$ & $<10$ & -- \\
\hline Phenol, water, unfiltered & -- & $<10$ & $<10$ & $<10$ & $<10$ & -- & $<10$ & $<10$ & -- \\
\hline Pyrene, total & -- & $<10$ & $<10$ & $<10$ & $<10$ & -- & $<10$ & $<10$ & -- \\
\hline Toxaphene, total & 3 & $<5$ & $<5$ & $<5$ & $<5$ & -- & $<5$ & $<5$ & -- \\
\hline $\begin{array}{l}\text { Benzene, 1,2,4-trichloro-, } \\
\text { water, unfiltered, recover- } \\
\text { able }\end{array}$ & -- & $<10$ & $<10$ & $<10$ & $<10$ & -- & $<10$ & $<10$ & -- \\
\hline
\end{tabular}


Table 4. Pesticide and semivolatile concentrations for samples collected at hot- and cold-water springs in 2000 and 2001.—Continued

[Base-flow sample collected September 2000; Stormflow sample collected October 2001; All concentrations for samples collected are in micrograms per liter; $<$, less than; --, data unavailable]

\begin{tabular}{|c|c|c|c|c|c|c|c|c|c|}
\hline \multirow[b]{2}{*}{ Constituent name } & \multirow[b]{2}{*}{$\begin{array}{l}\text { Maximum } \\
\text { contaminant } \\
\text { level' }\end{array}$} & \multicolumn{2}{|c|}{ Spring 49} & \multicolumn{2}{|c|}{ Spring 9} & \multicolumn{2}{|c|}{ Happy Hollow } & \multicolumn{2}{|c|}{ ArScenic } \\
\hline & & $\begin{array}{l}\text { Base } \\
\text { flow }\end{array}$ & $\begin{array}{l}\text { Storm- } \\
\text { flow }\end{array}$ & $\begin{array}{l}\text { Base } \\
\text { flow }\end{array}$ & $\begin{array}{l}\text { Storm- } \\
\text { flow }\end{array}$ & $\begin{array}{l}\text { Base } \\
\text { flow }\end{array}$ & $\begin{array}{l}\text { Storm- } \\
\text { flow }\end{array}$ & $\begin{array}{l}\text { Base } \\
\text { flow }\end{array}$ & $\begin{array}{l}\text { Storm- } \\
\text { flow }\end{array}$ \\
\hline $\begin{array}{l}\text { Benzene, 1,3-dichloro-, water, } \\
\text { unfiltered, recoverable }\end{array}$ & -- & $<10$ & $<10$ & $<10$ & $<10$ & -- & $<10$ & $<10$ & -- \\
\hline $\begin{array}{l}\text { Benzene, 1,4-dichloro-, water, } \\
\text { unfiltered, recoverable }\end{array}$ & -- & $<10$ & $<10$ & $<10$ & $<10$ & -- & $<10$ & $<10$ & -- \\
\hline $\begin{array}{l}\text { Benzene, o-dichloro-, water, } \\
\text { unfiltered, recoverable }\end{array}$ & -- & $<10$ & $<10$ & $<10$ & $<10$ & -- & $<10$ & $<10$ & -- \\
\hline $\begin{array}{l}\text { Ethane, hexachloro-, water, } \\
\text { unfiltered, recoverable }\end{array}$ & -- & $<10$ & $<10$ & $<10$ & $<10$ & -- & $<10$ & $<10$ & -- \\
\hline Hexachlorobutadiene, total & -- & $<10$ & $<10$ & $<10$ & $<10$ & -- & $<10$ & $<10$ & -- \\
\hline Naphthalene, total & -- & $<10$ & $<10$ & $<10$ & $<10$ & -- & $<10$ & $<10$ & -- \\
\hline
\end{tabular}

${ }^{1}$ U.S. Environmental Protection Agency, 2003. 
Table 5. Nutrient, major ion, trace element, isotope, radiochemical, physical property, and field-measurement data for samples collected at hot- and cold-water springs in water years, 1972, 2000, and 2001.

[BF, base-flow sample collected September 2000; SF, stormflow sample collected October 2001; BR, Bedinger and others, 1979; $<$, less than; E, estimated; --, data unavailable; mg/L, milligrams per liters; $\mu \mathrm{g} / \mathrm{L}$, micrograms per liter; pCi/L, picocuries per liter; VSMOW, Vienna Standard Mean Ocean Water; $\mu \mathrm{S} / \mathrm{cm}$ at $25 \mathrm{deg}$. C, microsiemens per centimeter at 25 degrees Celsius]

\begin{tabular}{|c|c|c|c|c|c|c|c|c|c|}
\hline \multirow[b]{2}{*}{ Constituent name } & \multicolumn{3}{|c|}{ Spring 42} & \multicolumn{3}{|c|}{ Spring 46} & \multicolumn{3}{|c|}{ Spring 33} \\
\hline & BF & SF & BR & BF & SF & BR & BF & SF & BR \\
\hline \multicolumn{10}{|l|}{ Nutrients, mg/L } \\
\hline Nitrogen nitrate, dissolved & $<0.5$ & -- & 0.0 & E.17 & -- & 0.0 & $<0.5$ & -- & 0.0 \\
\hline Phosphorus ortho, dissolved & $<0.5$ & -- & 0.04 & $<0.5$ & -- & 0.04 & $<0.5$ & -- & 0.02 \\
\hline \multicolumn{10}{|l|}{ Major ions, mg/L } \\
\hline Calcium, total & 39.3 & 41.2 & 45 & 43.5 & 41.7 & 45 & 42.6 & 41.6 & 45 \\
\hline Magnesium, total & 4.29 & 4.32 & 4.8 & 4.69 & 4.34 & 4.8 & 4.72 & 4.36 & 4.8 \\
\hline Potassium, total & $\mathrm{E} 1.31$ & E1.13 & 1.5 & E1.39 & E1.13 & 1.5 & E1.44 & E1.13 & 1.5 \\
\hline Sodium, total rec. & E3.32 & E2.56 & 4.0 & $\mathrm{E} 4.13$ & $\mathrm{E} 2.82$ & 4.0 & E3.93 & $\mathrm{E} 2.33$ & 4.0 \\
\hline Chloride, dissolved & $\mathrm{E} 2.3$ & E2.8 & 1.9 & E2.4 & E2.7 & 1.9 & E2.4 & $\mathrm{E} 2.7$ & 1.9 \\
\hline Fluoride, total & E.18 & E. 22 & 0.2 & E.19 & E. 22 & 0.2 & E.19 & E. 22 & 0.2 \\
\hline Silica, total & 40.8 & 36.3 & 42 & 45.6 & 36.8 & 42 & 44.9 & 38.3 & 42 \\
\hline Sulfate, dissolved & 7.1 & 7.3 & 8.6 & 7.3 & 7.1 & 7.8 & 7.5 & 7.2 & 8.2 \\
\hline \multicolumn{10}{|l|}{ Trace elements, $\mu \mathrm{g} / \mathrm{L}$} \\
\hline Aluminum, total & $<100$ & $<100$ & 0.0 & $<100$ & 106 & 0.0 & $<100$ & E95.0 & 0.0 \\
\hline Iron, total & E36.9 & E19.3 & 10 & E24.5 & $\mathrm{E} 44.3$ & 330 & E60.3 & E36.9 & 40 \\
\hline Manganese, total & 231 & 239 & 230 & 196 & 198 & 250 & 230 & 261 & 270 \\
\hline Strontium, total & 104 & 114 & 110 & 110 & 117 & 110 & 110 & 114 & 110 \\
\hline Zinc, total & 20.4 & E4.4 & 0.02 & $<20.0$ & $<20.0$ & 0.07 & E10.0 & E13.3 & 0.08 \\
\hline \multicolumn{10}{|l|}{ Isotopes and radiochemicals } \\
\hline$\delta^{13} \mathrm{C}, \%$ & -14.09 & -- & -- & -13.65 & & -14.8 & -13.89 & -- & -14.6 \\
\hline $\begin{array}{l}\text { Carbon-14, counting error, } \\
\text { water, filtered, percent }\end{array}$ & -- & -- & -- & 0.34 & -- & -- & -- & -- & -- \\
\hline $\begin{array}{l}\text { Carbon-14, water, filtered, } \\
\text { percent }\end{array}$ & -- & -- & -- & 37.72 & -- & -- & -- & -- & -- \\
\hline Tritium, total (pCi/L) & $<5.7$ & $<5.7$ & 2.7 & 5.7 & 0.6 & 3.1 & 6.7 & 3.5 & 0.9 \\
\hline $\begin{array}{l}\text { Tritium, total, } 2 \text { sigma preci- } \\
\text { sion estimate }(\mathrm{pCi} / \mathrm{L})\end{array}$ & 3.8 & 2.6 & 0.3 & 3.8 & 1.9 & 0.6 & 4.5 & 2.6 & 0.6 \\
\hline$\delta \mathrm{D}, \mathrm{VSMOW}, \%$ & -29.19 & -27.61 & -28 & -28.26 & -30.04 & -29 & -29.04 & -30.95 & -28 \\
\hline$\delta^{18} \mathrm{O}, \mathrm{VSMOW}, \%$ & -5.49 & -5.51 & -5.4 & -5.41 & -5.48 & -5.5 & -5.16 & -5.48 & -5.4 \\
\hline \multicolumn{10}{|l|}{$\begin{array}{l}\text { Physical properties and field } \\
\text { measurements }\end{array}$} \\
\hline $\begin{array}{l}\text { Total dissolved solids (resi- } \\
\text { due on evaporation at } 180 \\
\text { degrees Celsius }\end{array}$ & 194 & 182 & 188 & 198 & 179 & 187 & 194 & 188 & 188 \\
\hline pH, field (standard units) & 6.80 & 6.90 & 6.93 & 7.41 & 7.1 & 7.01 & 6.80 & 6.89 & 7.13 \\
\hline $\begin{array}{l}\text { Specific conductance }(\mu \mathrm{S} / \mathrm{cm} \text { at } \\
25 \text { deg. C) }\end{array}$ & 275 & 273 & 272 & 287 & 254 & 269 & 291 & 256 & 269 \\
\hline Water temperature (deg. C.) & 61.9 & 62.1 & 61.3 & 55.7 & 55.8 & 58.3 & 58.2 & 58.6 & 57.6 \\
\hline
\end{tabular}


Table 5. Nutrient, major ion, trace element, isotope, radiochemical, physical property, and field-measurement data for samples collected at hot- and cold-water springs in water years, 1972, 2000, and 2001.-Continued

[BF, base-flow sample collected September 2000; SF, stormflow sample collected October 2001; BR, Bedinger and others, 1979; $<$, less than; E, estimated; --, data unavailable; mg/L, milligrams per liters; $\mu \mathrm{g} / \mathrm{L}$, micrograms per liter; $\mathrm{pCi} / \mathrm{L}$, picocuries per liter; VSMOW, Vienna Standard Mean Ocean Water; $\mu \mathrm{S} / \mathrm{cm}$ at $25 \mathrm{deg}$. C, microsiemens per centimeter at 25 degrees Celsius]

\begin{tabular}{|c|c|c|c|c|c|c|c|c|c|}
\hline \multirow[b]{2}{*}{ Constituent name } & \multicolumn{3}{|c|}{ Spring 42} & \multicolumn{3}{|c|}{ Spring 46} & \multicolumn{3}{|c|}{ Spring 33} \\
\hline & BF & SF & BR & BF & SF & BR & BF & SF & BR \\
\hline $\begin{array}{l}\text { Alkalinity, dissolved ( } \mathrm{mg} / \mathrm{L} \text { as } \\
\left.\mathrm{CaCO}_{3}\right)\end{array}$ & 128 & 133 & 159 & 127 & 131 & 164 & 124 & 131 & 164 \\
\hline $\begin{array}{l}\text { Alkalinity, dissolved ( } \mathrm{mg} / \mathrm{L} \text { as } \\
\qquad \mathrm{HCO}_{3} \text { ) }\end{array}$ & 156 & 162 & 194 & 155 & 160 & 200 & 151 & 160 & 200 \\
\hline
\end{tabular}


Table 5. Nutrient, major ion, trace element, isotope, radiochemical, physical property, and field-measurement data for samples collected at hot- and cold-water springs in water years, 1972, 2000, and 2001.-Continued

[BF, base-flow sample collected September 2000; SF, stormflow sample collected October 2001; BR, Bedinger and others, 1979; <, less than; E, estimated; --, data unavailable; mg/L, milligrams per liters; $\mu \mathrm{g} / \mathrm{L}$, micrograms per liter; pCi/L, picocuries per liter; VSMOW, Vienna Standard Mean Ocean Water; $\mu \mathrm{S} / \mathrm{cm}$ at $25 \mathrm{deg}$. C, microsiemens per centimeter at 25 degrees Celsius]

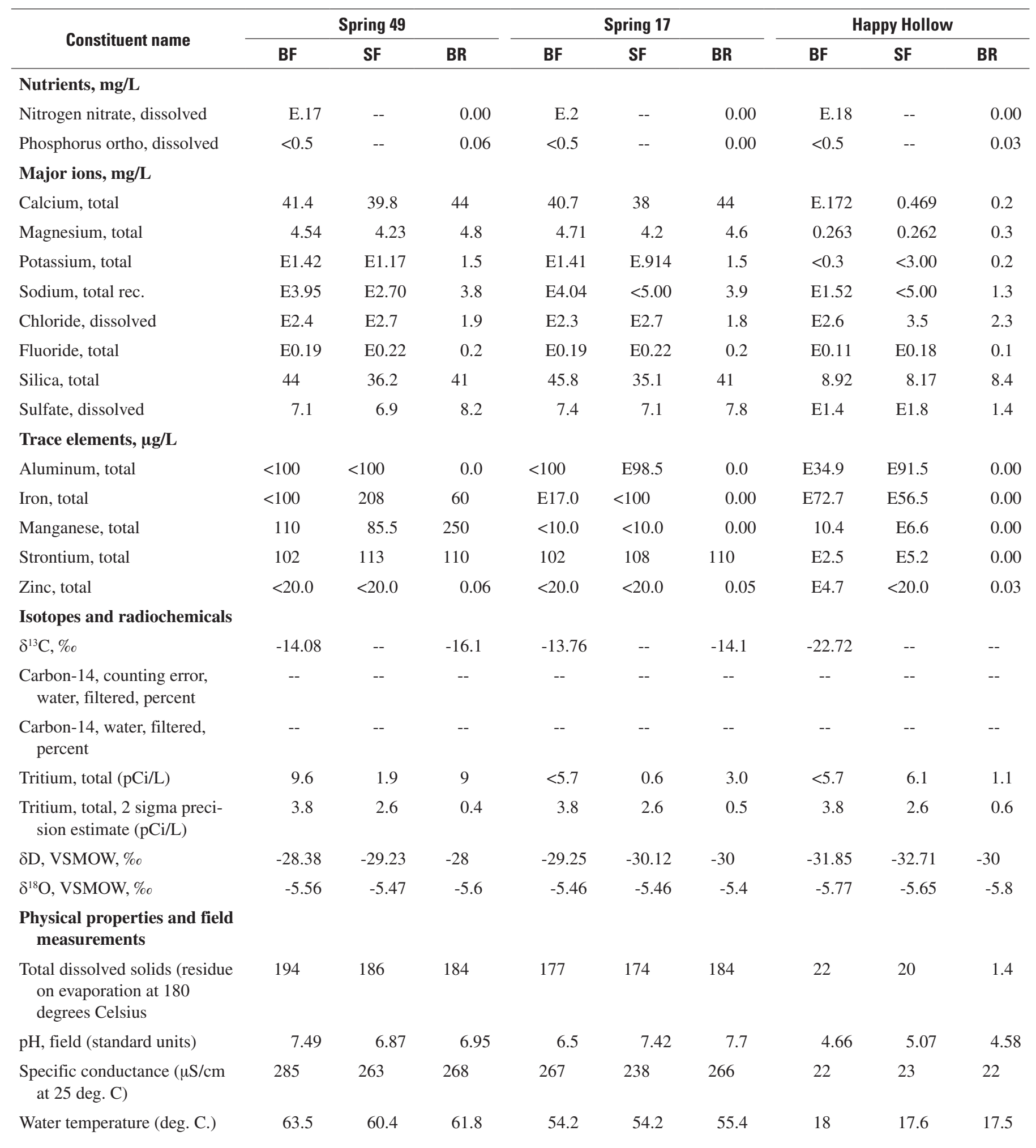


Table 5. Nutrient, major ion, trace element, isotope, radiochemical, physical property, and field-measurement data for samples collected at hot- and cold-water springs in water years, 1972, 2000, and 2001.-Continued

[BF, base-flow sample collected September 2000; SF, stormflow sample collected October 2001; BR, Bedinger and others, 1979; <, less than; E, estimated; --, data unavailable; mg/L, milligrams per liters; $\mu \mathrm{g} / \mathrm{L}$, micrograms per liter; pCi/L, picocuries per liter; VSMOW, Vienna Standard Mean Ocean Water; $\mu \mathrm{S} / \mathrm{cm}$ at $25 \mathrm{deg}$. C, microsiemens per centimeter at 25 degrees Celsius]

\begin{tabular}{|c|c|c|c|c|c|c|c|c|c|}
\hline Constituent name & \multicolumn{3}{|c|}{ Spring 49} & \multicolumn{3}{|c|}{ Spring 17} & \multicolumn{3}{|c|}{ Happy Hollow } \\
\hline $\begin{array}{l}\text { Alkalinity, dissolved ( } \mathrm{mg} / \mathrm{L} \text { as } \\
\left.\quad \mathrm{CaCO}_{3}\right)\end{array}$ & 124 & 131 & 155 & 118 & 122 & 160 & E1.3 & E1.2 & 1.0 \\
\hline $\begin{array}{l}\text { Alkalinity, dissolved ( } \mathrm{mg} / \mathrm{L} \text { as } \\
\left.\quad \mathrm{HCO}_{3}\right)\end{array}$ & 151 & 160 & 189 & 144 & 149 & 195 & E1.6 & E1.5 & 1.2 \\
\hline
\end{tabular}


For more information concerning the research described in this report, contact:

U.S. Geological Survey

Arkansas Water Science Center

401 Hardin Road

Little Rock, AR 72211-3528

(501) 228-3600

http://ar.water.usgs.gov 
